\title{
A Numismática na sala de aula: moedas que contam histórias.
}

Dissertação de Mestrado

Dissertação apresentada como requisito parcial para obtenção do grau de Mestre em Ensino de História (opção profissional) pelo Programa de Pósgraduação stricto sensu em Ensino de História PROFHISTÓRIA - do Departamento de História do Centro de Ciências Sociais da PUC-Rio.

Orientadora: Doutora Juçara da Silva Barbosa de Mello 
PROFHISTÓRIA

MESTRADO PROFISSIONAL EM ENSINO DE HISTORIA
Pontifícia Universidade Católlica $_{\text {and }}$

DO RIO DE JANEIRO

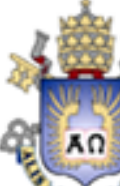

RICARDO LUIZ JONARD

\section{A Numismática na sala de aula: moedas que contam histórias.}

Dissertação apresentada como requisito parcial para obtenção do grau de Mestre em Ensino de História (opção profissional) pelo Programa de Pósgraduação Stricto Sensu em Ensino de História PROFHISTÓRIA - do Departamento de História do Centro de Ciências Sociais da PUC-RIO.

Prof. ${ }^{a}$ Doutora Juçara da Silva Barbosa de Mello

Orientadora

Departamento de História - PUC-Rio

Prof. ${ }^{a}$ Doutora Larissa Rosa Corrêa

Departamento de História - PUC-Rio

Prof. Doutor Paulo Knauss de Mendonça

Departamento de História - UFF

Rio de Janeiro, 9 de setembro de 2020. 
Todos os direitos reservados. É proibida a reprodução total ou parcial do trabalho sem autorização da universidade, do autor e do orientador.

\section{Ricardo Luiz Jonard}

Graduou-se em Licenciatura e Bacharelado em História pela Universidade Federal Fluminense em 2013. Especialista em Ensino na Educação Básica com ênfase em História pelo programa de Residência Docente do Colégio Pedro II. Mestrando em Ensino de História pelo PROFHISTÓRIA, núcleo PUC-Rio. Atua como professor de História em redes públicas municipais desde 2013.

Catalográfica

Jonard, Ricardo Luiz

A Numismática na sala de aula: moedas que contam histórias / Ricardo Luiz Jonard ; orientadora: Juçara Barbosa de Mello. - 2020.

142 f. : il. color. ; $30 \mathrm{~cm}$

Dissertação (mestrado)-Pontifícia Universidade Católica do Rio de Janeiro, Departamento de História, 2020. 


\section{Agradecimentos}

Aos que, de uma forma ou outra possibilitaram a realização desta pesquisa, deixo registrado os meus agradecimentos:

Inicialmente, aos meus alunos de toda a vida, e em especial aos do CIEP 492, em Quatis. Sem eles nada disso faria sentido.

À minha diretora Luciete do Nascimento, pelo apoio em providenciar rapidamente a documentação para a obtenção da bolsa e pela amizade de sempre.

À professora Ivana Stolze, pelo apoio na elaboração do projeto de pesquisa e pelas palavras de incentivo.

À minha orientadora Juçara Barbosa de Mello, pela excelente orientação, pelo incentivo, pelas críticas cirúrgicas e por me emprestar seu otimismo em todos os encontros.

À professora Larissa Corrêa e ao professor Paulo Knauss por aceitarem participar de minha banca, pelas críticas e sugestões durante a qualificação.

A todos os professores do PROFHISTÓRIA pelos excelentes cursos oferecidos.

Aos meus amigos de turma, em especial ao Diego, Naicon e Vitaly, pelo apoio, pelos ótimos trabalhos em grupo, pelos debates, cervejas e amizade.

Aos amigos do Rio e de Quatis, especialmente ao Bruno, Bruna, Celena, Cris, Lu, Nat e Rafa, pelo apoio e críticas durante a etapa final da pesquisa.

À Mariane Almeida, cunhada e minha irmã do coração, pelo apoio nas traduções, por ser prestativa e me ajudar em tudo.

Aos meus pais, Rita e Jorge, pelo apoio, educação, carinho e exemplo.

Muito obrigado a todos vocês.

O presente trabalho foi realizado com apoio da Coordenação de Aperfeiçoamento de Pessoal de Nível Superior - Brasil (CAPES) - Código de Financiamento 001 


\section{Resumo}

Jonard, Ricardo Luiz; Mello, Juçara da Silva Barbosa de. A Numis mática na sala de aula: moedas que contam histórias. Rio de Janeiro, 2020. 142 p. Dissertação de Mestrado - Departamento de História, Pontifícia Universidade Católica do Rio de Janeiro.

A partir de uma série de atividades focadas no manejo de moedas, esta dissertação centra-se na apresentação de um estudo de temas canônicos do currículo escolar, circunscritos à História do Brasil Republicano. O objetivo principal consistiu em promover a construção do conhecimento histórico na educação básica, colocando o aluno como sujeito da produção de saberes e o professor como mediador deste processo. Inicialmente, buscou-se analisar a produção dos alunos, visando identificar os efeitos que o manejo das fontes numismáticas pode ter sobre a sua aprendizagem quanto ao conhecimento histórico. Os passos seguintes foram: avaliar como os alunos fazem uso das ferramentas de análise; estimular o processo de aprendizagem a partir de linguagens diversificadas, bem como promover a proteção do patrimônio cultural. Os resultados obtidos no uso destas fontes foram avaliados no intuito de verificar a viabilidade ou não do uso da Numismática como um instrumento que permita a construção do processo de ensino e aprendizagem em História.

\section{Palavras-chave}

Ensino de História; Numismática; fontes históricas; patrimônio cultural 


\section{Abstract}

Jonard, Ricardo Luiz; Mello, Juçara da Silva Barbosa de. Numismatics in the classroom: coins that tell stories. Rio de Janeiro, 2020. 142p. Dissertação de Mestrado - Departamento de História, Pontificia Universidade Católica do Rio de Janeiro.

Based on a series of activities focused on the handling of coins, this dissertation focuses on the presentation of a study of canonical themes of the school curriculum, circumscribed to the history of Republican Brazil. The main objective was to promote the construction of historical knowledge in basic education, placing the student as the subject of knowledge production and the teacher as mediator of this process. Initially, we sought to analyze the students' production, aiming to identify the effects that the management of numismatic sources can have on their learning regarding historical knowledge. The next steps were: to evaluate how students use the analysis tools; to stimulate the learning process using diverse languages, as well as to promote the protection of the historical heritage. The results obtained in the use of these sources were evaluated in order to verify the feasibility or not of using numismatics as an instrument that allows the construction of the teaching and learning process in history.

\section{Keywords}

History teaching; numismatics; historical sources; cultural heritage 


\section{SUMÁRIO}

Introdução

10

1. O que é Numismática? 15

1.1. Uma breve História da moeda no Brasil República. 19

1.1.1. As moedas na Primeira República. 21

1.1.2. As moedas comemorativas. 25

1.1.3. As moedas como meio de propaganda. 29

1.1.4. As moedas e a economia. 31

1.1.5. As moedas da nova família do Real. 32

1.2. Patrimônio cultural e a educação patrimonial. 35

1.3. $\mathrm{O}$ uso das fontes históricas: breve panorama. 41

1.3.1. O uso das fontes em sala de aula: discussão. 46

2. Metodologia aplicada ao uso da Numismática para o ensino-aprendizagem de História na educação básica. 56

2.1. O município e a escola. 56

2.1.1. As turmas envolvidas. $\quad 59$

2.2. As fontes utilizadas. 60

2.3. Conservação, limpeza e acondicionamento das moedas. 61

2.4. O uso da tecnologia dos Smart Phones para a identificação de moedas. 64

2.5. Como examinar uma moeda. 66

2.6. Metodologia das atividades. 68

2.6.1. Atividade 1: A Numismática e os sujeitos históricos:

análise e problematização. $\quad 69$

2.6.2. Atividade 2: As moedas do Brasil e a Transição da Monarquia para a República. $\quad 72$

2.6.3. Atividade 3-Estado Novo: a Numismática e o culto

a imagem do Presidente Vargas. 76

2.6.4. Ditadura militar, crise econômica e a Numismática. 77 
3. Desenvolvimento das atividades e análise dos resultados. 80

3.1. Atividade 1.

3.2. Atividade 2.

3.3. Atividade 3.

3.4. Atividade 4.

Considerações finais. 103

$\begin{array}{ll}\text { Referências bibliográficas. } & 106\end{array}$

$\begin{array}{ll}\text { Sites Web apresentados. } & 108\end{array}$

$\begin{array}{ll}\text { Lista de anexos. } & 111\end{array}$ 


\section{Lista de Figuras}

Figura 1 - Moeda do Brasil Império. 23

Figura 2 - Duas moedas da chamada Primeira República. 24

Figura 3 - Moeda em comemoração ao $4^{\circ}$ Centenário do

Descobrimento do Brasil. 25

Figura 4 - Moeda comemorativa ao bicentenário da

morte de Tiradentes. $\quad 26$

Figura 5 - Moeda em comemoração ao centenário da

Independência. $\quad 27$

Figura 6 - Moeda comemorativa ao sesquicentenário da Independência do Brasil. 28

Figura 7 - Moeda do Estado Novo. 30

Figura 8 - Moedas da $2^{\mathrm{a}}$ família do Real. 34

Figura 9 - Morfologia de uma moeda. 66

Figura 10 - Atividade de registro de fontes numismáticas. 72

Figura 11 - Imagens da monarquia. $\quad 74$

Figura 12 - Símbolos republicanos.

Figura 13 - Moedas produzidas pelo grupo. 83

Figura 14 - Moedas produzidas pelo segundo grupo. 83

Figura 15 - Efígie dos próprios alunos e do professor nas novas moedas produzidas. 86

Figura 16 - Efígie de Zumbi dos Palmares, de um indígena Tupi, e do Cristo Redentor, respectivamente. 87

Figura 17 - Etapas da análise das fontes numismáticas. 90

Figura 18 - Confecção dos envelopes e a organização do acervo estudado. $\quad 92$

Figura 19 - Imagens postas sobre as carteiras para observação dos alunos. 93

Figura 20 - Um dos conjuntos de moedas analisadas pelos alunos. $\quad 97$ 


\section{Introdução}

A ideia para a elaboração desta pesquisa não surge de agora. Ela surge de um gosto antigo por colecionar moedas que me fizeram enxergar, já como professor de História, o potencial da Numismática em proporcionar um processo de ensino e aprendizagem mais proveitoso na disciplina. É preciso retroceder no tempo, quando na infância ganhei de presente do meu pai duas moedas: um Iene japonês e os cinco mil Cruzeiros em homenagem a Tiradentes. Não foi um presente aleatório. Ele mantinha essas moedas guardadas em sua gaveta e eu, desde muito novo, sempre curioso, buscava aquelas peças para manuseá-las. Achava o máximo o fato dos japoneses fazerem uma moeda com um furo no centro, como Iene, ou então admirava a beleza da moeda de Cruzeiro com a efígie de Tiradentes. Com o passar do tempo, já adolescente, a coleção ganhou corpo após heranças e da compra de novas peças.

Sem dúvida o interesse pelo estudo das moedas desenvolveu mais ainda o meu gosto pelo estudo da História. Sempre, por minha conta, as classificava, buscava saber mais sobre o período em que elas foram cunhadas, e sobre os personagens nelas representados. Acredito que a falta de um rigor metodológico para o estudo destas moedas tenha me prejudicado neste sentido, mas só o simples despertar de interesse pelo estudo da História é algo a se considerar, e creio que isso é algo relevante a ser transmitido aos alunos.

Assim, a vontade para realizar esta pesquisa no âmbito do PROFHISTÓRIA surge de uma inquietante procura por novas metodologias aplicadas ao ensino de História que buscasse uma diversificação das abordagens e métodos utilizados em sala para além das aulas expositivas, fazendo uso de algo presente no cotidiano da totalidade dos alunos: as moedas. A proposta visa facilitar o processo de aprendizagem do educando a partir da análise de fontes, colocando-o como centro do processo de produção do conhecimento histórico e o professor como um mediador e não um transmissor deste conhecimento. Defender esta abordagem é ampará-la dentro da base lógica científica, onde os alunos deixam de ser reprodutores de conteúdo e passam a construí-lo. 
Talvez, os processos inflacionários vividos pelo Brasil nas últimas décadas tenham levado as pessoas a desprezarem as moedas, que acabam por tornar-se um peso desnecessário no bolso, ficando muitas das vezes esquecida, como ocorreu nos períodos de hiperinflação que vivemos nos últimos trinta e cinco anos. Fato esse que não anima muito os mais jovens a se interessar pela Numismática. Ou então como ressalta Gonçalves:

\begin{abstract}
"Expostos cotidianamente a essa extensa e diversificada teia de objetos, sua relevância social e simbólica, assim como sua repercussão subjetiva em cada um de nós, termina por nos passar despercebida em razão mesmo da proximidade, do aspecto familiar e do caráter de obviedade que assume."1
\end{abstract}

No entanto, quando o assunto é abordado em sala de aula, os alunos se veem entusiasmados pelo tema. Muitos relatam que possuem em casa moedas do tempo de seus pais ou avós, que estão guardadas em algum lugar, e se prontificam a levá-las na aula seguinte para mostrar tal achado ao professor e aos colegas. Alguns ficam chateados por muitas destas moedas terem um valor comercial baixo, por não serem raras. Porém, todas possuem um valor histórico profundo, e por isso vale a pena tentar descobrir sua origem e as circunstâncias de sua emissão ou até mesmo os motivos que levaram seus responsáveis a guardá-las. Nas aulas, ao estimular a curiosidade e a pesquisa, essas moedas podem ser o início de uma coleção ou podem fazer nascer um interesse pelo estudo mais aprofundado da Numismática e da História.

A justificativa para a escolha das moedas do período republicano encontrase em duas razões. Como as fontes utilizadas para a análise dos alunos serão oriundas de acervo pessoal, e visto que grande parte deste acervo consta de moedas que datam da Primeira República até a chamada Nova República, optouse por utilizá-las dada sua maior quantidade, maior grau de preservação, e fácil substituição em caso de dano devido ao intenso manuseio.

Outra razão parte da visão otimista de que as moedas do Brasil República são uma fonte poderosa de informação, mas que são esquecidas por pesquisas na área. Para o numismata Alan Jean Costilhes "as moedas metálicas dos nossos dias não possuem o mesmo valor histórico, pois não tem, nas sociedades atuais, a

\footnotetext{
1 GONÇALVES, José Reginaldo Santos. Teorias Antropológicas e Objetos Materiais. In:
} Antropologia dos objetos: coleções, museus e patrimônio. Rio de Janeiro, 2007. p. 14. 
mesma importância que tiveram nas sociedades as quais até agora nos referimos [da antiguidade e medieval] ${ }^{\prime 2}$. É fato que ao longo do tempo elas perderam o seu protagonismo, porém apenas como meio de pagamento, dado o avanço do papel moeda, seguido de cheques, cartões magnéticos, internet bankings e toda a gama de possibilidades de pagamentos por meio digital atualmente.

Primeiramente, seu uso como fonte em sala de aula já se justificaria apenas por colocar o aluno em contato direto com um documento original produzido em outra época. Mais ainda, elas são reflexo direto das circunstâncias políticas, econômicas, culturais de determinado período. Embora múltiplas sejam as possibilidades de seu estudo, a dificuldade desta pesquisa encontra-se justamente no fato de poucos serem os trabalhos que tratem da Numismática na História do Brasil República. O que pode parecer a princípio um tema original torna-se desafiador não dispor de muitos trabalhos acadêmicos que tratem deste assunto para um maior embasamento.

A partir de uma busca por trabalhos acadêmicos realizada em diversas bases de dados como o Portal Capes ${ }^{3}$, a base da biblioteca da PUC-Rio ${ }^{4}$, Scielo $^{5}$ e Jstor $^{6}$ foram encontrados poucos trabalhos dentro do recorte temporal que esta pesquisa vai se aprofundar. Muitas das pesquisas acadêmicas encontradas tratam do estudo das moedas da Antiguidade Clássica como os trabalhos de Carlan ${ }^{7}$ sobre a moeda em Roma e na Macedônia. O leitor poderá conhecer os poucos trabalhos encontrados ao longo desta pesquisa, utilizados como referência bibliográfica. Já os livros didáticos consultados, por sua vez, não consideram as moedas do Brasil como fonte de estudo e problematização, mas o mesmo é feito com moedas Romanas, por exemplo. Caso encontrado nos manuais da editora FTD, no livro História, Sociedade e Cidadania, escrito por Alfredo Boulos Junior ${ }^{8}$.

\footnotetext{
${ }^{2}$ COSTILHES, Alain Jean. O que é numismática. Editora brasiliense. São Paulo, 1985. p 65.

${ }^{3}$ http://www.periodicos.capes.gov.br/

${ }^{4} \mathrm{http}: / /$ www.dbd.puc-rio.br/sitenovo/

${ }^{5} \mathrm{http}: / /$ www.scielo.org/php/index.php

${ }^{6}$ https://www.jstor.org/

7 CARLAN, C. U. Moeda e poder em Roma: um mundo em transformação. São Paulo: Annablume, 2013.

${ }^{8}$ BOULOS JUNIOR, Alfredo. História: sociedade e cidadania. $9^{\circ}$ ano. São Paulo: FTD, 2016.
} 
Assim, pretende-se, nesta pesquisa, investigar e testar a viabilidade do uso destas moedas como um tipo de fonte histórica material que apresenta uma linguagem diversificada e que proporciona várias possibilidades de problematização aos alunos. Estas possibilidades serão pensadas para ir além da utilização das fontes para validar o que foi dito pelo professor ou então para tornar as aulas mais atrativas. A intenção é fazer o aluno manejar estes documentos a partir de uma perspectiva crítica.

Aqui, no primeiro capítulo, foram introduzidos os assuntos abordados nesta dissertação bem como as discussões de cunho teórico. Incialmente foi escrito um pouco sobre a Numismática fazendo também um histórico sobre a trajetória da constituição deste ramo do conhecimento enquanto ciência. Em seguida, para embasar os trabalhos em sala em termos de conteúdo e possibilidades, foi feito um breve histórico da moeda no Brasil República. E por fim, como discussão teórica, buscou-se compreender melhor questões relativas ao patrimônio cultural, bem como sobre o uso de fontes históricas em sala de aula.

O capítulo dois tem um caráter mais metodológico. Buscou-se entender um pouco da atmosfera onde a pesquisa foi aplicada. E, para isso, foi preciso abordar o município, a escola, e os alunos que participaram das atividades. Também se encontram disponíveis informações sobre as fontes numismáticas utilizadas na pesquisa, assim como informações de caráter técnico sobre a Numismática: como examinar uma moeda; conservação, limpeza e acondicionamento do material; e sobre o uso de novas tecnologias para a identificação de moedas. Por fim, todas as atividades aplicadas foram descritas detalhadamente.

No terceiro capítulo foram apresentados os resultados obtidos. A partir da observação de todas as atividades aplicadas em todas as turmas foram feitos relatos pormenorizados de cada etapa do processo, destacando tanto os aspectos positivos quanto os negativos. Ao final de cada relato apresenta-se uma consideração sobre a atividade em questão, finalizando com as considerações finais da proposta de pesquisa.

Ao final, o professor poderá encontrar um guia para o uso da Numismática em sala de aula. O guia é um resumo de toda esta dissertação, contendo passos importantes para o trabalho com moedas nas aulas de História. As atividades 
propostas e analisadas nesta pesquisa também estão no guia, em forma mais sistematizada e objetiva, facilitando a sua aplicação. 


\section{O que é Numismática?}

A Numismática é o estudo cientiffico das moedas, cédulas e medalhas. A análise Numismática pode oferecer ao historiador uma gama de informações através de uma apurada metodologia e de técnicas de pesquisa específicas. A origem do nome Numismática vem do grego nomisma e do latim nummus, ambos os termos utilizados por estes povos para designar suas moedas. Já o termo moeda, por sua vez, origina-se em referência a deusa romana protetora do dinheiro, Juno Moneta, cujo templo na cidade de Roma cunhavam-se moedas ${ }^{9}$. O nome Moneta é oriundo da palavra latina moneo que significaria "algo que nos lembre, que nos traz à memória" ${ }^{\text {, }}$, termo muito sugestivo sobre o mundo de possibilidades que a Numismática pode proporcionar aos estudos históricos.

Dentre as múltiplas possibilidades de informações que uma fonte desta importância pode oferecer destaca-se a economia, a cronologia, a metrologia, a epigrafia, a heráldica, a simbologia, a iconografia, a geografia, bem como a metalurgia. Todas estas possibilidades de análise estão atreladas a determinados processos históricos, e devem ser utilizadas pelos historiadores à exaustão. Por processo histórico entende-se todo um conjunto de acontecimentos vividos pelos seres humanos que em contínua sucessão, seja através de transformações ou permanências, desencadeiam no objeto que a história procura estudar.

A relação do metal-moeda com estes processos é evidente, pois toda moeda é testemunho de seu próprio tempo. Elas circularam pelas mãos das pessoas em todas as eras desde a antiguidade; após séculos de coadjuvantismo, ressurgiu com a revolução comercial da Europa medieval a partir do século XI; exaltaram figuras de líderes como Júlio César, no denário Romano, e Getúlio Vargas, em seus réis e cruzeiros no Estado Novo; impulsionaram revoltas urbanas, dos vinténs aos vinte centavos; da prata de Potosí ao níquel Soviético, metais que deixaram registros materiais valiosíssimos por onde passaram; sua cunhagem é resultado da ação dos homens que ao intento de melhor regular a economia e as trocas comerciais deixaram como evidência não apenas aspectos econômicos das sociedades, como também políticos e socioculturais.

\footnotetext{
${ }^{9}$ COSTILHES, Alain Jean. O que é numismática. Editora brasiliense. São Paulo, 1985. p. 9.

${ }^{10}$ CARLAN, Cláudio Umpierre; FUNARI, Pedro Paulo. Moedas, a Numismática e o estudo da História. São Paulo: Annablume/Fapemig/Unifal/Unicamp, 2012. p. 25.
} 
Para o historiador, como visto, seu potencial de estudo é considerável, visto que a moeda é uma fonte histórica material ${ }^{11}$, como um grande monumento, uma ruína, ou uma pintura rupestre que é preciso analisar para desvendar sobre o contexto histórico em que foi produzida. Contribuindo para esta compreensão ampla da noção de fonte histórica, Lucien Febvre afirma que:

"A História se faz com documentos escritos, quando existem. Mas ela pode e deve ser feita com toda a engenhosidade do historiador... Com palavras e sinais. Paisagens e telhas. Formas de campos e ervas daninhas. Eclipses lunares e cordas de atrelagem. Análises de pedras pelos geólogos e de espadas de metal pelos químicos. Numa palavra, com tudo aquilo que, pertencendo ao homem, depende do homem, serve o homem, exprime o homem, significa a presença, a atividade, os gostos e as maneiras de ser do homem" $"$.

Assim, levando-se em consideração a noção sobre o documento histórico descrita por Lucien Febvre, e acreditando neste potencial objeto de pesquisa que são as moedas, não somente no meio acadêmico, mas também como um facilitador no processo de ensinar e aprender História para alunos da educação básica, é que surge esta proposta de pesquisa com a Numismática em sala de aula.

A Numismática não é uma área de estudo recente. Até hoje muitas pesquisas na área estão direcionadas ao período da antiguidade clássica, e este interesse pela compreensão das histórias grega e romana, surge no chamado renascimento cultural. Ela inicia-se com a prática do colecionismo destes objetos de metal, vindo da Itália o pioneirismo desta prática a partir das coleções de Francesco Petrarca, cujo intuito era o de resgatar e valorizar o passado grecoromano $^{13}$. Também se destaca, no século XVI, os estudos dos sistemas monetários antigos, promovido pelo humanista francês Guillaume Budé ${ }^{14}$.

Naquela época, a consolidação das práticas colecionistas, que vieram com o resgate de moedas a partir de escavações aumentou consideravelmente a

\footnotetext{
${ }^{11} \mathrm{O}$ conceito de cultura material, segundo Ulpiano Bezerra de Meneses, refere-se a todo segmento do universo físico socialmente apropriado. Neste estudo trataremos especificamente do metalmoeda.

${ }^{12}$ FEBVRE, Lucien. Combates pela história. $3^{\mathrm{a}}$ ed. Lisboa, Editorial Presença, 1989. p. 249.

${ }^{13}$ CARLAN, Cláudio Umpierre. Moeda e poder em Roma: um mundo em transformação. São Paulo: Annablume, 2013.

${ }^{14}$ CARLAN, Cláudio Umpierre; FUNARI, Pedro Paulo. Moedas, a Numismática e o estudo da História. São Paulo: Annablume/Fapemig/Unifal/Unicamp, 2012. p. 17.
} 
quantidade de coleções, mas não se limitou a atitudes isoladas de conhecedores do assunto, surgindo também as sociedades numismáticas. Um dos primeiros trabalhos publicados sobre o tema data do período renascentista. O catálogo Illustirum imagines, obra publicada por Andrea Fulvio, continha diversas imagens de moedas do período clássico com o objetivo de expor figuras de personagens famosos da antiguidade ${ }^{15}$.

Adentrando a idade moderna, já no século XVIII, destaca-se a iniciativa de uma sociedade britânica que patrocinava estudos das antigas sociedades gregas e romana. A chamada Society of Dilletanti incentivou pesquisas arqueológicas destinadas a conhecer as ruínas greco-romanas o que resultou no achado de vasto material arqueológico numismático nas regiões escavadas ${ }^{16}$. Nesta época, existe o avanço da valorização da ciência, com a adoção de métodos mais rigorosos para os estudos cientificos. Posteriormente, com o movimento Iluminista, houve o avanço das atividades museológicas ilustradas que buscaram na arte uma regeneração cultural. Neste contexto é criado o Museu Britânico cujas coleções, das quais se destacam as exposições de moedas, mostram as diferenças culturais entre diversas sociedades ${ }^{17}$.

Porém, somente em finais do século XIX a Numismática irá adquirir um caráter cientifico de fato, com formulação de métodos de pesquisa próprios ${ }^{18}$. A partir deste momento, podem-se destacar diversos estudos da moeda que versavam sobre, por exemplo: "as organizações monetárias, a função social da moeda e o seu significado econômico e social, a análise da circulação monetária, das manipulações dos pesos e das ligas (rebaixamento de valor) praticadas pelo Estado, a reconstituição das emissões"19.

No Brasil, a Numismática vai se desenvolver justamente neste período acompanhando o modelo científico europeu. As classes mais abastadas, sendo a antiga nobreza imperial, com destaque para a figura do Imperador D. Pedro II, foram os responsáveis pela montagem e guarda das primeiras coleções de moedas

\footnotetext{
${ }^{15}$ CARLAN, Cláudio Umpierre. Op. Cit.

${ }^{16}$ CARLAN, Cláudio Umpierre; FUNARI, Pedro Paulo. Op. Cit. p. 41.

${ }^{17}$ CARLAN, Cláudio Umpierre. Op. Cit.

${ }^{18}$ COSTILHES, Alain Jean. O que é numismática. Editora brasiliense. São Paulo, 1985. p. 81.

${ }^{19}$ Ibidem.
} 
no país $^{20}$. Outro registro pioneiro de coleções de moedas no Brasil fazem referência ao diplomata suíço Jules Milet, que foi cônsul em Salvador em $1870^{21}$. Milet foi responsável pelas primeiras publicações sobre Numismática no país, das quais se destacam os livros As moedas do Brasil Colônia (1897), Moeda Fiduciária do Brasil (1903) e Moedas do Brasil Independente (1905). Com o advento da República, a produção cientifica sobre Mumismática no país ficaria a cargo, inicialmente, dos museus e das sociedades numismáticas, com destaque a Sociedade Numismática Brasileira criada em 1924.

A atuação dos museus brasileiros na montagem e na guarda de valiosíssimos acervos de moedas, bem como no apoio à realização e à divulgação de pesquisas acadêmicas sobre o assunto é algo que deve ser mencionado. Destaque maior vai para o Museu Histórico Nacional no Rio de Janeiro, com um acervo totalizando mais de cento e cinquenta mil itens, fazendo de sua coleção Numismática a mais importante e expressiva da América do $\mathrm{Sul}^{22}$. Não apenas em termos quantitativos o acervo do MHN merece destaque, mas sua coleção também é fruto de diversas pesquisas acadêmicas no país, como os trabalhos de Claudio Umpierre Carlan citados nesta pesquisa.

Também no Rio de Janeiro existe a coleção do Centro Cultural Banco do Brasil (CCBB). Seu acervo conta com cerca de trinta e oito mil peças, dentre cédulas e moedas, nacionais e estrangeiras. Parte deste acervo está exposto na Galeria de Valores do centro cultural, tratando de forma muito didática o desenvolvimento do dinheiro no Brasil e no mundo. Na exposição sobre a Numismática do país, conta com moedas que vem desde o período colonial até os dias de hoje, com destaque para a moeda que retrata a coroação do imperador brasileiro em 1822, uma das mais valiosas da numária brasileira.

Ainda na capital fluminense, o Museu da Casa da Moeda (CMB), reaberto para visitação desde 2018 após quase 30 anos fechado, também mantém aberto ao público uma exposição sobre Numismática brasileira. Além da exposição de seu acervo histórico, a CMB mantém uma exposição permanente chamada "Dos Réis

\footnotetext{
${ }^{20}$ CARLAN, C. U. Arqueologia e Numismática: A História Antiga e a Cultura Material. Agenda social (UENF), v.4, 2010. p. 25.

${ }^{21}$ Ibidem

${ }^{22}$ Website oficial do Museu Histórico Nacional: https://mhn.museus.gov.br/index.php/acervo/ Acesso em: 17 de mar de 2020.
} 
ao Real", mostrando a história da moeda no Brasil desde a época colonial, dando ênfase ao Brasil República, tema muito pertinente a esta pesquisa de mestrado.

Outro museu de grande importância para a Numismática brasileira é o Museu Herculano Pires (Itaú Numismática) na capital paulista. Seu acervo contém mais de cinco mil peças. A exposição, com ênfase em moedas brasileiras, possui mil e quinhentos itens expostos, com destaque a moedas de ouro e prata. Por se tratar de um museu privado oriundo de coleções particulares, e com o patrocínio de uma grande instituição financeira brasileira, o museu realiza um trabalho de repatriação de moedas de maior valor para o Brasil através da compra no exterior. Além da visitação aberta ao público, o acervo exposto deste museu foi organizado em um belíssimo livro publicado por Alfredo e Fernanda Gallas intitulado "As moedas contam a História do Brasil.,23

Estes museus, e outros não listados aqui, possuem um papel muito importante, pois contribuem na valorização da Numismática brasileira. Não se trata de rejeitar os estudos sobre a moeda na antiguidade clássica, e sim de valorizar o potencial das moedas brasileiras na construção do conhecimento histórico e proporcionar maior entendimento e gosto pelo estudo da história do Brasil. Esta pesquisa seguirá por este caminho, valorizando a pesquisa da Numismática brasileira do período republicano tão pouco explorada no meio acadêmico. Assim, no subcapítulo a seguir, pode-se ter contato sobre a história do meio circulante metálico durante a República, prova das possibilidades que estes estudos podem proporcionar, seja dentro das universidades ou no próprio chão da escola que é o principal propósito deste trabalho.

\subsection{Uma breve história da moeda no Brasil República.}

A proposta desta seção não é produzir um relato enciclopédico dando conta de toda a história da cunhagem de moedas do período republicano. A ideia de se escrever uma breve história da cunhagem de moedas desta época é para dar fundamento às atividades que serão descritas nesta pesquisa. Logo, servirá de

\footnotetext{
23 GALLAS, Alfredo; GALLAS Fernanda Disperati. As moedas contam a história do Brasil.
} São Paulo. Magma Editora Cultural, 2007. 
apoio também para que professores possam aproveitá-la, caso demostrem interesse em trabalhar com as atividades que foram aqui propostas.

Para aqueles que queiram se debruçar mais sobre o tema e que não disponha das fontes numismáticas, um bom lugar para ter um contato inicial com este material é o website Moedas do Brasil ${ }^{24}$. Neste sítio, pode-se buscar muita informação sobre a Numismática brasileira e buscar através de um vasto catálogo as fontes necessárias para o desenvolvimento dos trabalhos.

Para quem não dispõe de uma coleção, por menor que seja, e deseja montá-la para trabalhar com moedas em sala de aula a sugestão é buscar através de antiquários, feiras de antiguidades, pela internet através do website Mercado Livre $^{25}$ ou em lojas especializadas em Numismática. Na cidade do Rio de Janeiro, uma boa dica é garimpar na tradicional feira de antiguidades da Praça XV que ocorre aos sábados, ou recorrer as tradicionais casas de Numismática no centro da cidade, como a Numismática Vieira ${ }^{26}$ ou a DPL Numismática ${ }^{27}$.

É importante destacar que existe maior facilidade para encontrar moedas do Período Republicano que de períodos anteriores nestes lugares. Isso se dá devido a dois fatores: o primeiro é que por serem mais recentes, sendo as primeiras cunhagens feitas em 1889, encontram-se em melhor grau de preservação se comparado a moedas do Império e do período colonial.

Outro elemento que facilita a maior preservação das moedas são os metais utilizados. Muitas das moedas do Brasil do período Republicano foram cunhadas com metais mais resistentes como o níquel, o cuproníquel $^{28}$ e nos últimos quarenta anos o aço inoxidável. Para os leigos em metalurgia, como efeito de comparação, basta verificar as moedas da primeira família do Real produzidas em aço inox ainda em circulação. É raro perceber sinais visíveis de desgaste ou oxidação nestas moedas devido à boa qualidade do metal utilizado. Sem dúvidas, estudá-las será um deleite paras os historiadores e numismatas do futuro.

\footnotetext{
${ }^{24}$ http://www.moedas dobrasil.com.br/moedas/

${ }^{25} \mathrm{https}: / /$ www.mercadolivre.com.br/

${ }^{26}$ Tradicional casa de numismática localizada na cidade do Rio de Janeiro, na Rua do Rosário, 61 $-\mathrm{D}$, Centro.

${ }^{27}$ Outra famosa casa de numismática na cidade, localizada na Rua da Assembleia, 10 - 10A, Centro.

${ }^{28}$ Nome dado à liga metálica que mescla o cobre e o níquel, comumente empregado na cunhagem de moedas.
} 
É bem verdade que foram cunhadas moedas de níquel no II Reinado, porém a dificuldade em encontrá-las leva a refletir sobre o segundo fator aqui elencado que se refere quantidade de emissões monetárias. Já nos anos iniciais do Brasil República, por razões socioeconômicas que serão explicadas adiante, uma quantidade maior de dinheiro passou a ser emitida pelo governo de Deodoro da Fonseca. Com o passar das décadas, com maior geração de riqueza, e o aumento populacional, mais dinheiro também foi sendo emitido.

Para exemplificar, fazendo uma checagem na quantidade de moedas cunhadas no final da Monarquia, no início da República e nos dias atuais pode-se ter uma noção do que foi dito. O níquel de 200 Réis emitido em 1886 teve uma tiragem de 176.500 unidades $^{29}$. Estes mesmos 200 Réis, em 1889 com o país já sob um governo presidencialista, foram emitidos mais de cinco milhões de moedas $^{30}$. Atualmente, tomando como exemplo uma moeda de 50 centavos da $2^{\mathrm{a}}$ família do Real cunhada no ano de 2013, tem-se o total de 350 milhões de unidades produzidas ${ }^{31}$.

Isso ajuda e explicar o porquê de ser mais fácil montar uma coleção de moedas do período Republicano brasileiro para se trabalhar em sala de aula. Essa maior quantidade disponível resulta, inclusive, no preço mais baixo de investimento na montagem de uma coleção. Quem não dispõe de tempo para a busca e nem dinheiro para isso, uma simples impressão colorida das moedas para se trabalhar na escola pode ser utilizada. Os modelos podem ser retirados no website do catálogo de moedas citado anteriormente. Embora surta efeitos pedagógicos importantes, é válido destacar que a utilização de impressões coloridas das moedas irá suprimir o encantamento oferecido aos alunos de poder aprender história manuseando fontes históricas peculiares e originais.

\subsubsection{As moedas na Primeira República.}

O advento da República no Brasil representou uma ruptura com o sistema político monárquico, fruto das tensões envolvendo, de um lado, o governo

\footnotetext{
${ }^{29}$ MALDONADO, Rodrigo. Catálogo de moedas brasileiras. 1500 - 2017. Quinta Edição. 2017

${ }^{30}$ Ibidem.

${ }^{31}$ Ibidem.
} 
imperial e de outro os setores ligados à elite agrária cafeicultora e o exército. Embora as transformações no espectro político-administrativo tenham sido significativas desde o princípio com a adoção do presidencialismo e a introdução do sistema federativo, para a massa da população, no geral, acredita-se que pouco se fez notar nos anos iniciais pós-proclamação ${ }^{32}$.

Ainda há de se considerar que a maioria da população vivia no campo, e que existia ainda uma grande camada das populações urbanas formadas por recém-libertos do regime de escravidão ${ }^{33}$. Assim, possivelmente, uma das primeiras formas em que se fez notar pelo povo as transformações políticas do momento foi através das novas emissões de cédulas e moedas pelo governo Republicano. E as moedas, por sua vez, ganham um destaque não pelo seu valor financeiro, pois nesta época elas já haviam perdido espaço para as cédulas ${ }^{34}$, mas sim pelo seu poder de alcance chegando aos bolsos dos mais pobres aos mais ricos, letrados ou não, no campo ou na cidade.

Estas transformações puderam ser percebidas através dos símbolos reproduzidos nestas novas moedas recentemente cunhadas. Tão logo proclamada a República, um dos primeiros decretos instituído pelo então presidente Manoel Deodoro da Fonseca e seu ministro da Fazenda Ruy Barbosa autorizava a cunhagem de novas moedas de ouro, prata, níquel e bronze, bem como autorizava os novos desenhos republicanos:

\begin{abstract}
"O Marechal Manoel Deodoro da Fonseca, Chefe do Governo Provisorio, constituido pelo Exercito e Armada, em nome da Nação, attendendo a que, por ter sido extincto no Brazil o systema monarchico representativo e achar-se estabelecida a forma republicana, tornar-se necessario alterar o cunho das moedas de ouro, prata, nickel e bronze actualmente em circulação, resolve approvar os desenhos que com este baixam, propostos pelo Director interino da Casa da Moeda para servirem de typo á abertura dos cunhos da primeira edição republicana das referidas moedas, substituindo-se nas de ouro o
\end{abstract}

\footnotetext{
32 O historiador José Murilo de Carvalho destaca a falta de participação popular no movimento Republicano por uma autoexclusão do povo, que não via na República possibilidades efetivação de um aumento da participação popular. Ver CARVALHO, José Murilo de. Os bestializados: o Rio de Janeiro e a República que não foi. São Paulo: Companhia das Letras, 1987.

33 FAUSTO, Boris. História concisa do Brasil. São Paulo: Edusp/Imprensa Oficial do Estado, 2001.

$34 \mathrm{O}$ advento do papel-moeda durante o Império tirara o protagonismo do metal-moeda como principal meio circulante de pagamento no país. As moedas, ou vinténs como se dizia, desde então passaram sempre a ser consideradas para o troco.
} 
lemma-Liberdade e Patria - pela data de 15 de novembro de 1889 -; e bem assim autorisar a cunhagem das moedas do novo typo, observadas quanto ao peso, modulo, liga, tolerancia e quantidade das de cada metal e valor, as disposições dos decretos até agora em vigor." 35

Com isso, as moedas que no momento final do Segundo Reinado reproduziam símbolos da monarquia como a efígie de Dom Pedro II em sua fase idosa bem como brasão Imperial passaram então a representar os símbolos da República como um forma de legitimação de poder deste novo sistema de governo $^{36}$. Estas moedas seriam emitidas em quantidade superior ao período anterior, em face da nova realidade vivida pelo país, com a introdução do trabalho assalariado e com o ingresso de grandes levas de imigrantes europeus, fazendo então com que fosse necessário o aumento do meio circulante no país ${ }^{37}$.
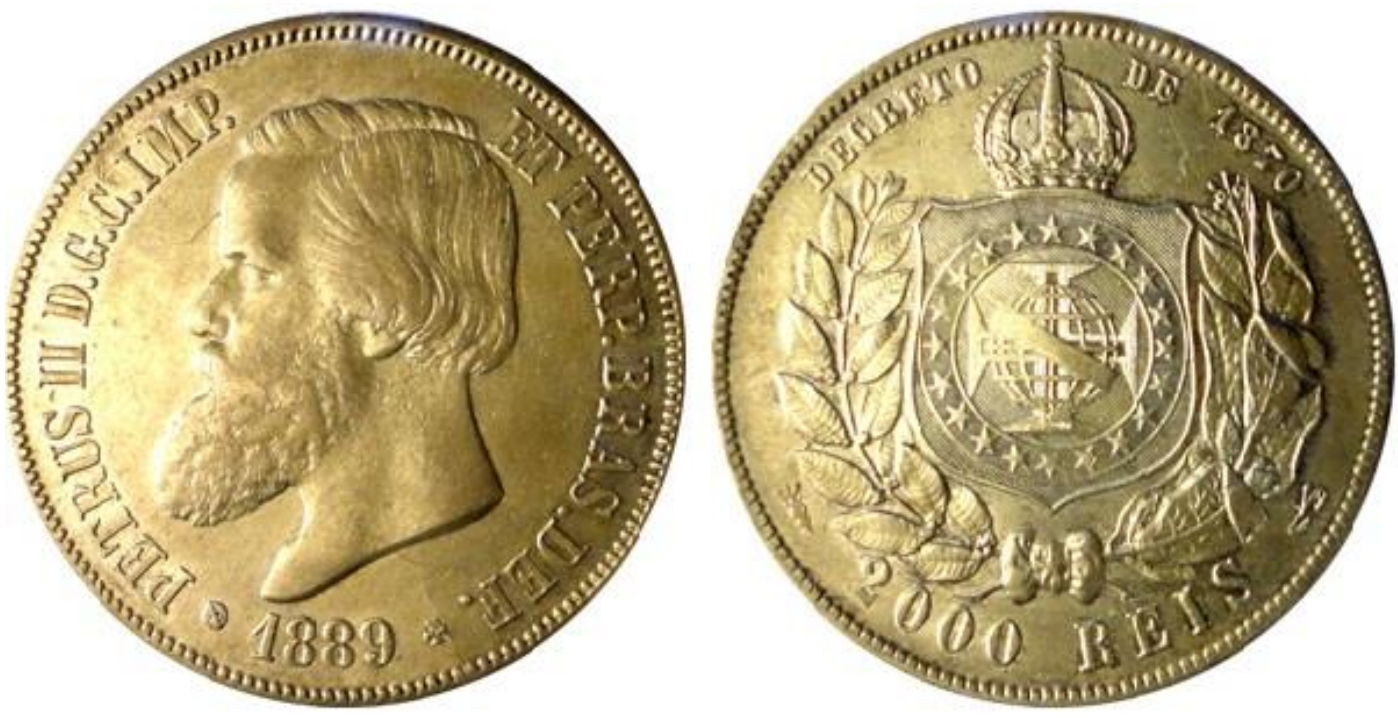

Figura 1 - Moeda do Brasil Império. No anverso: Busto do Imperador Pedro II na fase idosa, circundado pela inscrição PETRUS II. D. G. C. IMP. ET PERP. BRAS. DEF. e o ano de cunhagem entre uma pequena esfera armilar à esquerda e uma pequena cruz da Ordem de Cristo, à direita. No reverso, Armas do Império, ladeado acima pela inscrição DECRETO DE 1870 e abaixo pelo dístico do valor facial entre um pequeno caduceu, símbolo do comércio, à esquerda e uma pequena balança, à direita. Coleção Eduardo Rezende.

35 Decreto No 54-B, de 13 de dezembro de 1889, disponível em https://www2.camara.leg.br/legin/fed/decret/1824-1899/decreto-54-b-13-dezembro-1889-504306publicacaooriginal-1-pe.html Acesso em: 13 de jan. de 2020.

36 JURT, Joseph. O Brasil: Um Estado Nação a ser construído. O papel dos símbolos nacionais, do Império à República. Revista Mana, vol.18, nº 3. Rio de Janeiro, 2012.

37 FAUSTO, Boris. História concisa do Brasil. São Paulo: Edusp/Imprensa Oficial do Estado, 2001. p. 143. 
A simbologia republicana não ficou restrita aos símbolos oficiais instituídos por decreto. Além do brasão das armas e o cruzeiro do sul, a figura da mulher com barrete frígio ${ }^{38}$ com a ideia de representar a liberdade proporcionada pela instauração da República também fora incluída nas cunhagens das novas moedas. A figura da mulher, símbolo da República, se tornou tão popular que foi o único símbolo mantido nas moedas em todos os diferentes padrões monetários implantados durante Brasil República (exceto no Cruzeiro Real de 1993 e 1994), estando hoje cunhada nas moedas de $\mathrm{R} \$ 1,00$.
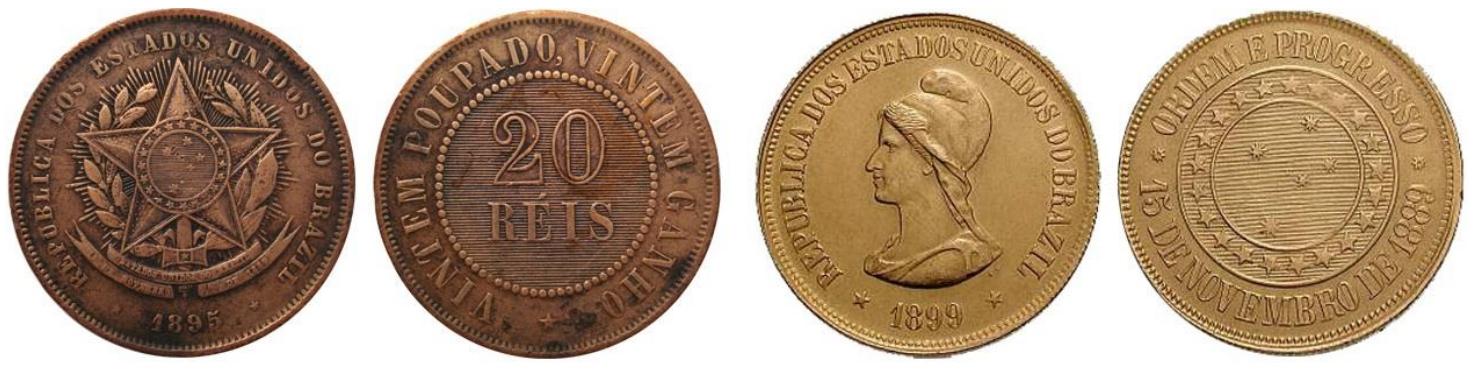

Figura 2 - Duas moedas da chamada Primeira República. A primeira: no anverso, Armas Nacionais orladas pela inscrição "REPUBLICA DOS ESTADOS UNIDOS DO BRAZIL" e era entre estrelas. No reverso, Valor 20 RÉIS dentro de anel de pérolas e orlado pela inscrição "VINTEM POUPADO, VINTEM GANHO". A segunda moeda: no anverso, busto representando a República e a liberdade, com o barrete frígio, circundada pela inscrição "REPUBLICA DOS ESTADOS UNIDOS DO BRAZIL" e era entre estrelas. No reverso, Cruzeiro do Sul orlado por anel de 21 estrelas, na orla superior a inscrição "ORDEM E PROGRESSO - 15 DE NOVEMBRO DE 1889” separada em flanco por duas estrelas. Coleção Itaú Numis mática.

\footnotetext{
${ }^{38}$ O barrete frígio é um tipo de touca ou gorro utilizado inicialmente pela população da Frígia, situada na península da Anatólia, Turquia. Este gorro teria sido utilizado pelos republicanos franceses que lutaram pela tomada da Bastilha em 1789. Por isso, tornou-se um forte símbolo da liberdade promovido pelo regime republicano.
} 


\subsubsection{As moedas comemorativas.}
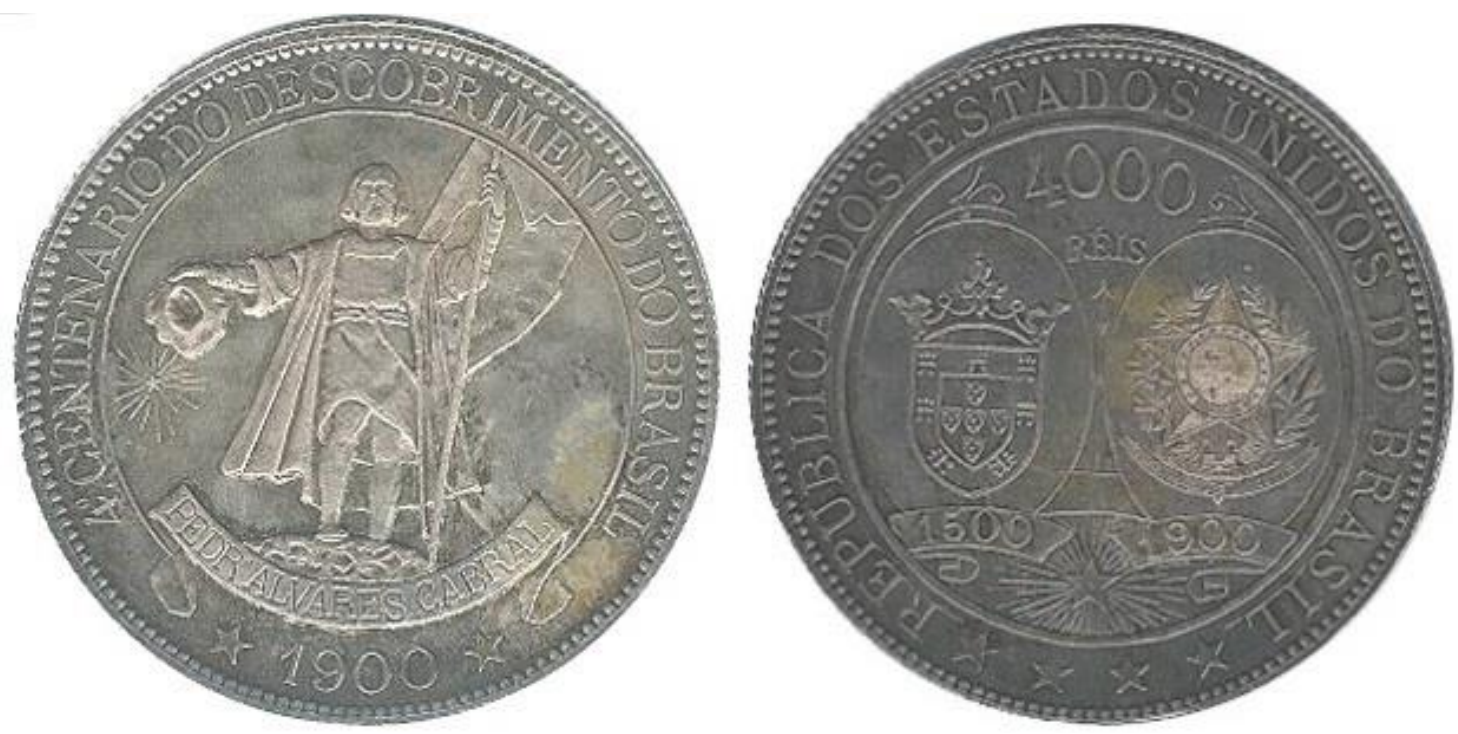

Figura 3 - $4^{\circ}$ Centenário do Descobrimento do Brasil - Cabral 20 raios. No anverso, Cabral, sobre faixa inscrita "PEDR'ALVARES CABRAL", segurando bandeira e chapéu. Sob o chapéu, sol com 20 raios. Inscrição "4. CENTENARIO DO DESCOBRIMENTO DO BRASIL” e data 1900. No reverso, "4000 réis" acima de escudos de Portugal e Brasil com datas 1500 e 1900 orlados pela inscrição "REPUBLICA DOS ESTADOS UNIDOS DO BRASIL". Coleção Itaú Numismática.

Durante a Primeira República destaca-se o pioneirismo no país ao lançarem a primeira série de moedas comemorativas do Brasil. Em homenagem ao $4^{\circ}$ centenário do descobrimento do Brasil em 1900, foi lançada uma série de moedas de prata com a efígie do navegador português Pedro Álvares Cabral. Curiosamente o primeiro nome alçado a categoria de herói da nação, Tiradentes, tendo inclusive sua data de morte transformada em feriado nacional em $1890^{39}$, não fora homenageado neste momento, mesmo passando pela data simbólica de 1892, centenário da Conjuração Mineira.

Esta reparação viria cem anos depois, em 1992, com o lançamento de uma bela moeda comemorativa de cinco mil cruzeiros produzida em aço inox, cujo anverso registrava a efígie de Tiradentes com os dizeres Liberdade e Cidadania. $\mathrm{Na}$ história da cunhagem de moedas do Brasil República, esta apresentava o

\footnotetext{
${ }^{39} \mathrm{O}$ decreto $\mathrm{n}^{\circ} 155$-B de 14 de janeiro de 1890 declara os dias de festa nacional, dos quais destacase 0 dia 21 de abril como o dia de Tiradentes. Em https://www2.camara.leg.br/legin/fed/decret/1824-1899/decreto-155-b-14-janeiro-1890-517534publicacaooriginal-1-pe.html Acesso em: 16 de jan. de 2020.
} 
segundo maior valor facial ${ }^{40}$ dentre todas as moedas do período, perdendo apenas para as moedas de ouro cunhadas no início do período republicano que não possuíam circulação comum $^{41}$. Atualmente, Tiradentes também é homenageado nas moedas de cinco centavos da $2^{\mathrm{a}}$ família do Real. Fica a sugestão para o professor utilizar as moedas do mártir da Conjuração Mineira nas aulas de História de forma a problematizar a sua representação imagética messiânica.
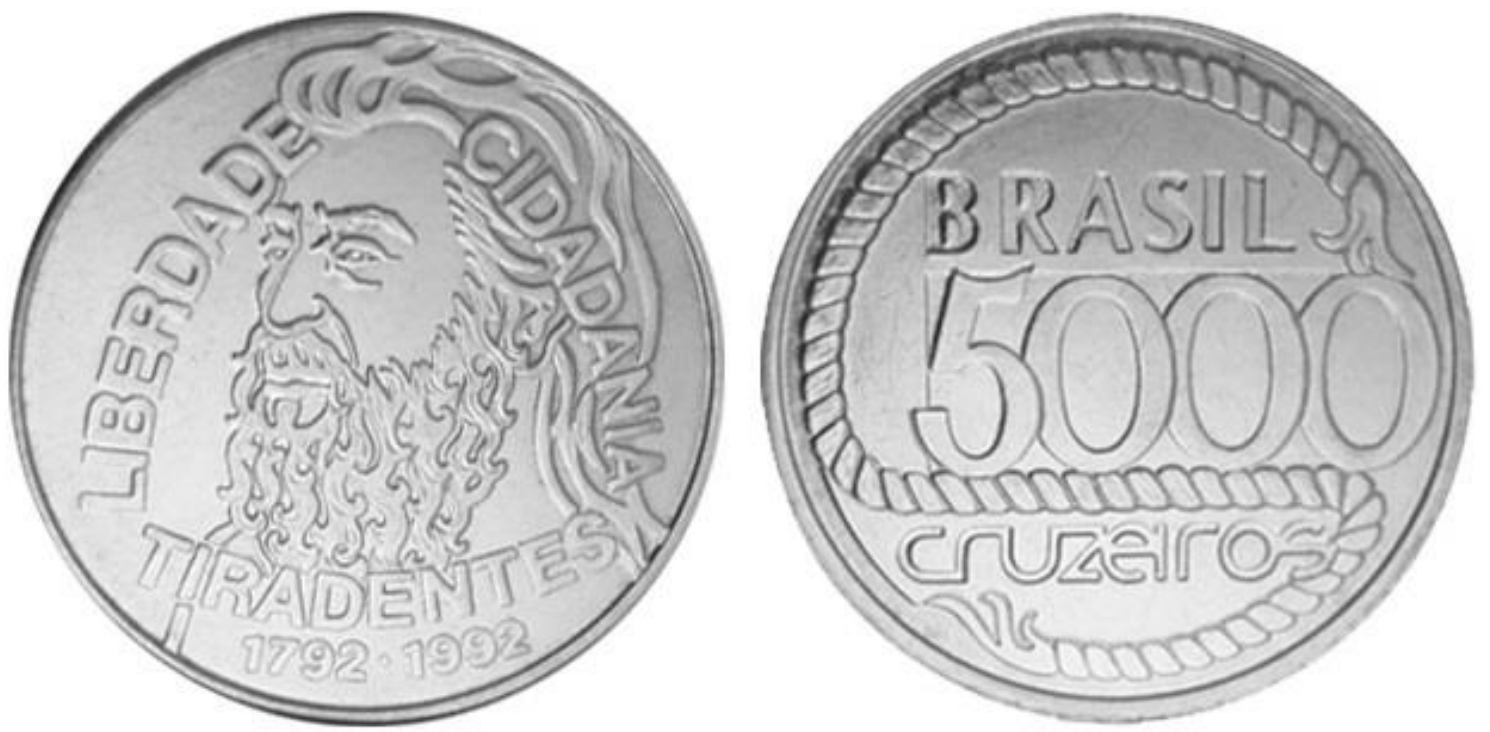

Figura 4 - Moeda Comemorativa do bicentenário da morte de Tiradentes. No anverso, efígie de Tiradentes e as legendas LIBERDADE, CIDADANIA e TIRADENTES. No reverso, Valor de 5000 cruzeiros, dístico BRASIL e corda sem laço. Coleção Eduardo Rezende.

Talvez um dos casos mais interessantes ao se pontuar quando se discute moedas comemorativas é o caso das homenagens aos aniversários da independência do Brasil. Daí tem-se dois exemplos. No centenário da independência, em 1922, no último ano de presidência de Epitácio Pessoa, o governo emitiu moedas comemorativas cujo anverso fora cunhado as efigies perfiladas do imperador D. Pedro I e do então presidente da República. No reverso cunhou-se uma tocha centralizada com dois ramos cruzados, um com a coroa símbolo da Monarquia e ou outro o barrete frígio que era a representação do regime republicano.

\footnotetext{
${ }^{40}$ Valor facial é o valor apresentado no reverso da moeda.

${ }^{41}$ http://www.moedasdobrasil.com.br/moedas/ranking.asp\#facialR Acesso em 16 de jan. de 2020.
} 

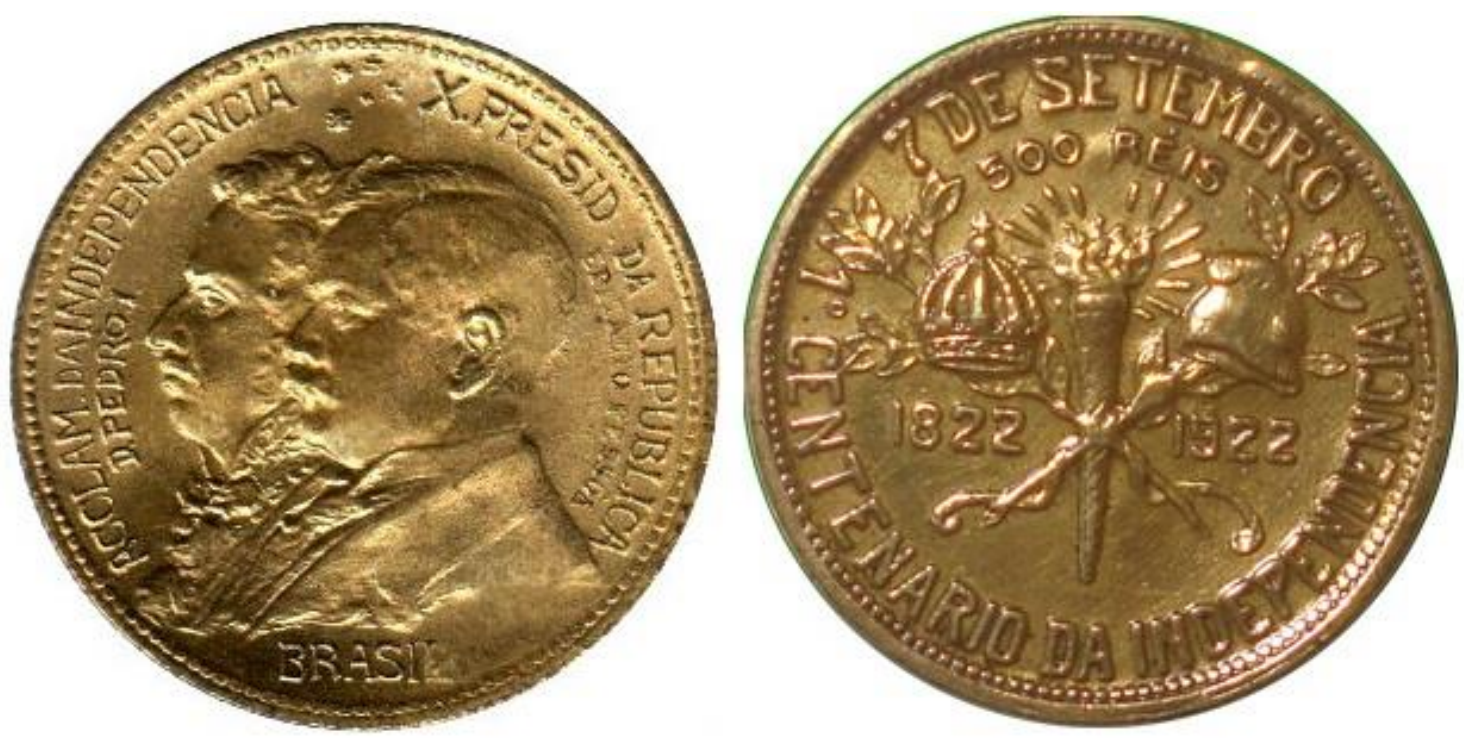

Figura 5 - Moeda em comemoração ao centenário da independência. No anverso, bustos de Dom Pedro I e presidente Epitácio Pessoa envolvidos por inscrição ACCLAM. DA INDEPENDENCIA * * X PRESID. DA REPUBLICA - BRASIL. No reverso, Tocha com dois ramos, um com coroa e outro com barrete da liberdade, o valor 500 réis e as datas 1822 e $1922-7$ de setembro, $1^{\circ}$ centenário da independência. Coleção Eduardo Rezende.

Aqui não será discutido o uso da imagem nas moedas de um presidente em exercício de seu mandato, visto que não foi uma característica do governo de Epitácio Pessoa a prática do culto a sua personalidade. Mas destaca-se o reaparecimento dos símbolos monárquicos passados trinta e três anos da instauração da República. A preocupação inicial dos governos pós-proclamação em se apagar a memória da monarquia através de seus símbolos já não estava em pauta em um sistema de governo já consolidado depois de três décadas de existência.

A exaltação aos símbolos monárquicos que estas moedas trazem revelam também certa simpatia do governo com o antigo regime. Corroborando tal ideia, um dos atos de Epitácio Pessoa foi a revogação, em 1920, da Lei de Banimento. Esta Lei, instituída em 1889, determinava o exílio de Dom Pedro II e de toda a família imperial, além de proibi-los de possuir propriedades no país. Outro ato, em 1921, foi o translado dos despojos do último Imperador brasileiro e de sua esposa Teresa Cristina de Portugal ao Brasil fazendo parte de um contexto mais amplo referente às comemorações do centenário da nação no ano seguinte ${ }^{42}$.

\footnotetext{
42 FAGUNDES, Luciana Pessanha. De volta à terra pátria: o translado dos restos mortais de D. Pedro II e Thereza Cristina para o Brasil (1921). XXVVIII Simpósio Nacional de História, Florianópolis, 2015.
} 
O outro exemplo ocorreu em 1972. Em comemoração ao sesquicentenário da Independência, durante o regime militar, o governo emitiu moedas comemorativas cujo anverso trazia as efígies perfiladas de Dom Pedro I e do então presidente Emílio Garrastazu Médici, ideia semelhante às moedas de 1922. A ideia para a cunhagem desta moeda está inserida em um contexto maior. Esse momento comemorativo representou a "euforia gerada pelos anos de ouro do Milagre brasileiro [...] uma festa grandiosa, prevista para ter duração de quase seis meses e que mobilizou o país de norte a sul, apelando ao imaginário cíviconacionalista brasileiro" ${ }^{43}$.
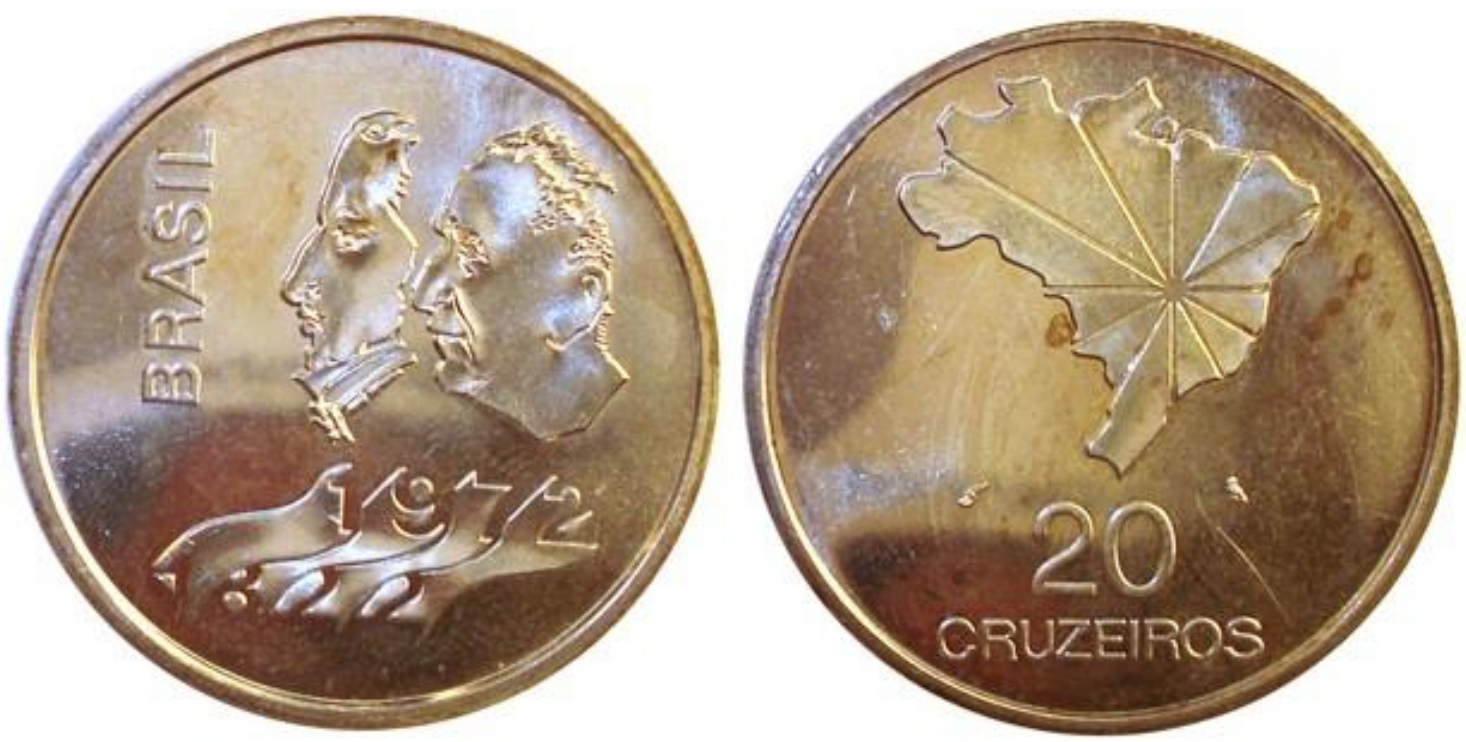

Figura 6 - Moeda comemorativa ao sesquicentenário da Independência do Brasil - 1822-1972. No anverso, D. Pedro I, Presidente Médici e símbolo do Sesquicentenário da Independência. No reverso, mapa do Brasil sobre o valor de 20 cruzeiros. Coleção Eduardo Rezende.

Pensando nos tempos atuais, quando o bicentenário da nação se aproxima, existe uma expectativa sobre as moedas comemorativas que serão cunhadas no ano de 2022. Algo é tido como certo, é improvável que se cunhe uma moeda com a efígie do atual presidente Jair Bolsonaro (tal como Epitácio Pessoa e Médici), pois desde a Constituição de 1988 é vedado ao governo o uso de "símbolos ou

43 CORDEIRO, Janaina Martins. As comemorações do Sesquicentenário da Independência em 1972: uma festa esquecida? Anais do XXVI Simpósio Nacional de História - ANPUH, São Paulo, 2011. 
imagens que caracterizem promoção pessoal de autoridades"44. Aliás, esta pode ser uma sugestão de atividade a ser trabalhada em sala de aula, onde os alunos, a partir de suas vivências e escolhas, criem as novas moedas dos 200 anos da Independência do Brasil a partir de um debate inicial que problematize o seu uso, como nos casos citados anteriormente, para a legitimação de determinados ideais.

\subsubsection{As moedas como meio de propaganda.}

Ao falar sobre o uso de imagens de autoridades na cunhagem de moedas para promoção pessoal, o caso mais emblemático no Brasil República não pode deixar de ser registrado, inclusive dela resultou uma atividade muito bem aproveitada pelos alunos nesta pesquisa. Esse caso passou-se durante a Era Vargas.

No ano de 1937, o presidente Getúlio Vargas instaura a ditadura do Estado Novo. Dentre muitas características, o modelo de Estado imposto pelo presidente implantou o Departamento de Imprensa e Propaganda (DIP), um órgão responsável por controlar os meios de comunicação, bem como produções artísticas, além de contribuir para o culto à imagem de Getúlio Vargas ${ }^{45}$.

Em consonância com a politica de promoção a imagem do líder, a Casa de Moeda do Rio de Janeiro passou a cunhar moedas estampando a efígie do presidente. Assim, foram emitidas moedas de 100, 200, 300 e 400 Réis com o perfil de Vargas de 1938 até $1942^{46}$, como mostra a imagem abaixo. No mesmo período, líderes Europeus como Benito Mussolini, Adolf Hitler e Joseph Stalin que, assim como Getúlio, promoveram o culto a própria imagem, também emitiram moedas estampando suas efígies como forma de legitimação e propaganda.

Artigo 37, Parágrafo $1^{\circ}$ da $\quad$ CF de 1988, disponível em https://www.senado.leg.br/atividade/const/con1988/CON1988 05.10.1988/art 37.asp

${ }^{45}$ FAUSTO, Boris. História concisa do Brasil. São Paulo: Edusp/Imprensa Oficial do Estado, 2001.

${ }^{46}$ MALDONADO, Rodrigo. Catálogo de moedas brasileiras. 1500 - 2017. Quinta Edição. 2017. 

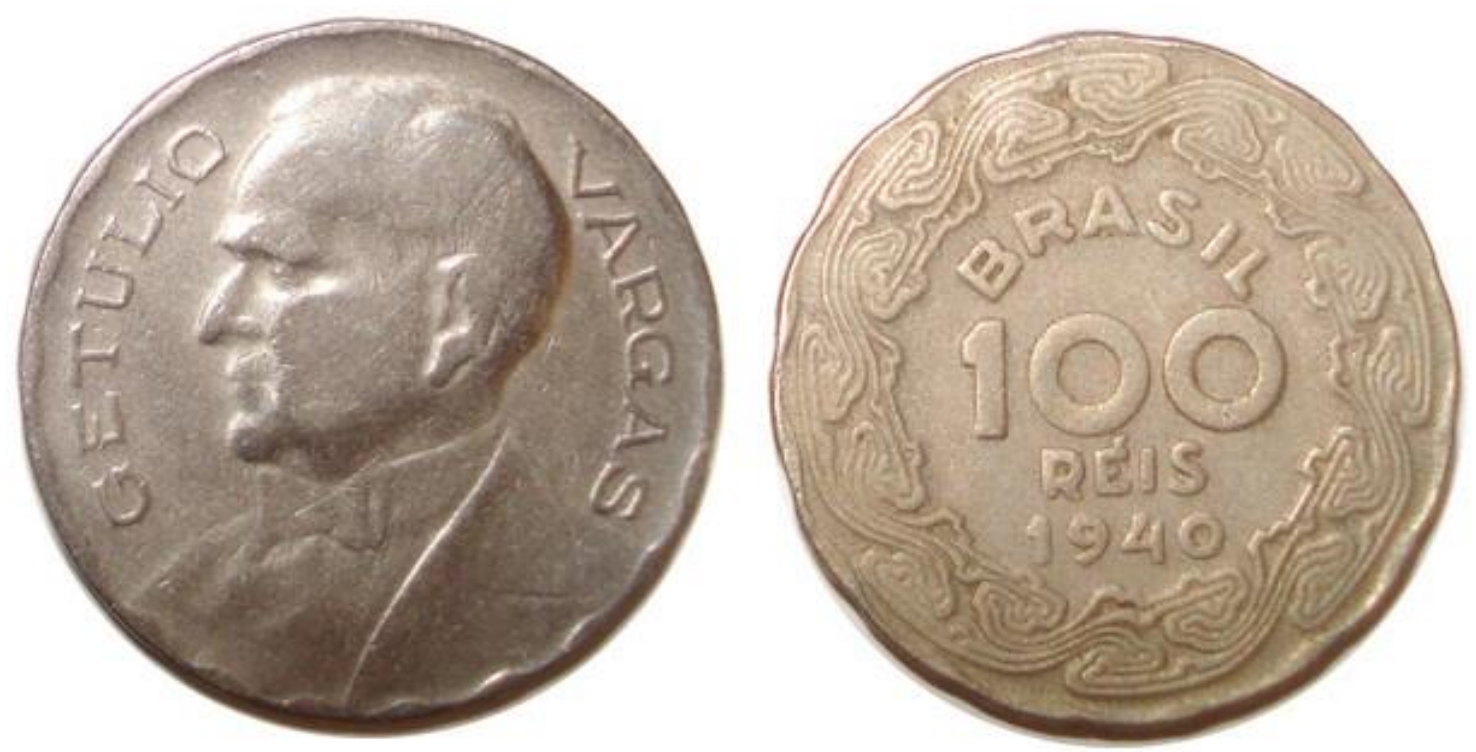

Figura 7 - Moeda do Estado Novo. No anverso, busto do perfil de Getúlio Vargas no centro, interrompendo a legenda de seu nome e sobrenome, à esquerda e à direita. No reverso, o valor e a data em três linhas, tudo encimado pela palavra BRASIL, inscrita circularmente. Em orla, um ornamento marajoara. Coleção Eduardo Rezende.

A implantação de um novo padrão monetário, o Cruzeiro, em 1942 não interrompeu o projeto Varguista sobre o meio circulante brasileiro na cunhagem de moedas com sua efígie. Aliás, a implantação deste sistema é mais um caso onde o simbólico se sobrepõe ao econômico dentro da Numismática provando que as moedas podem nos dizer muito mais sobre questões culturais, sociais e políticas que a própria economia em si.

De todos os padrões monetários instituídos durante o período Republicano, o Cruzeiro talvez seja a moeda que mais tenha sido dotado deste caráter simbólico. Os outros, de fato, estão associados a questões econômicas de controle dos processos inflacionários, como o caso de nossa atual moeda, o Real.

O projeto do Cruzeiro não teve sua concepção originada no Estado novo, sendo fruto de intensos debates desde os primeiros anos da instituição República $^{47}$. Porém, foi durante a ditadura de Vargas que este projeto pode ser consolidado. E a preocupação de substituir o padrão dos Mil-Réis, que embora estivesse inflacionado, estaria relacionada a "abandonar a antiga moeda que ainda era a mesma utilizada no período colonial português, adotar um sistema de divisão

47 RAMOS, Mariana Contin. Com Vargas no bolso: o meio circulante brasileiro como ideologia e propaganda do Estado Novo. Dissertação de mestrado. UNIRIO. Rio de Janeiro, 2015. P. 31. 
da moeda que fosse semelhante aos sistemas monetários de outras nações e escolher um nome que tivesse características brasileiras" 48 .

\subsubsection{As moedas e a economia.}

Embora se tenha priorizado um olhar sobre o meio circulante brasileiro a partir de outras perspectivas, estudar as questões econômicas do Brasil a partir das moedas pode tornar este tema mais interessante aos alunos. Esta é, também, uma oportunidade para se trabalhar a História e a Matemática de forma interdisciplinar, como proposto na atividade sobre a economia durante o regime militar presente nesta pesquisa.

Sob a ditadura dos militares (1964-1985), o Brasil viveu períodos distintos em relação ao crescimento da economia. A este respeito, muito se destaca nos livros didáticos a chamada época do "milagre econômico", momento entre os anos de 1968 e 1973 em que o país obteve crescimento econômico expressivo ${ }^{49}$. Porém, no último decênio do regime o país viveu um período conturbado na economia marcado por fortes processos inflacionários, aumento da pobreza, da desigualdade social e pouco crescimento do seu produto interno bruto (PIB), registrando, também, índices negativos de crescimento ${ }^{50}$. E uma das formas de entender este momento se faz possível através da análise das moedas cunhadas na época. Embora existam diversos indicadores de inflação no país que são o meio mais adequado para entendê-la, por meio da numária pode-se fazer o aluno perceber como a inflação atingiu o país em curto período através da emissão de novos e maiores valores pelo governo.

Como dito, perceber estes reajustes nos valores das moedas não é o modelo ideal para se medir a inflação. Para medi-la existem indicadores próprios para tal, como o $\operatorname{IPCA}^{51}$ ou o INPC ${ }^{52}$, índices utilizados atualmente. Porém, é

\footnotetext{
${ }^{48}$ Ibidem.

${ }^{49}$ FAUSTO, Boris. História concisa do Brasil. São Paulo: Edusp/Imprensa Oficial do Estado, 2001.

${ }^{50}$ Ibidem.

${ }^{51}$ O IPCA é o Índice de Preços para o Consumidor Amplo. Esse índice é medido mensalmente pelo IBGE para identificar a variação dos preços no comércio. Ele é considerado, pelo Banco Central, o índice brasileiro oficial da inflação ou deflação.
} 
notável que estas mudanças nas moedas ocorrem para acompanhar os processos de alta inflacionária. Assim, através da percepção dos constantes alterações dos valores monetários verificados nas fontes é que será possível fazer o educando inferir sobre as transformações econômicas do período, entendendo isso como um indicativo de crise.

\title{
1.1.5. As moedas da nova família do Real.
}

As atuais moedas brasileiras em circulação também são conhecidas como a

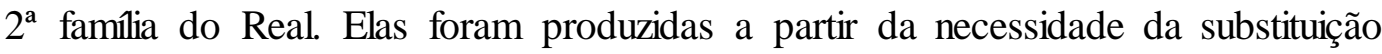
da $1^{\text {a }}$ Familia, considerado um projeto feito às pressas, que gerou muita crítica por parte da população por apresentar pouca distinção entre elas, dificultando seu uso cotidiano $^{53}$. Essa reclamação do brasileiro quanto ao uso das novas moedas ganham corpo, pois depois de um longo período de hiperinflação os centavos voltariam a ter poder de compra com a implantação do Plano Real em 1994.

Apesar da crítica popular e da falta de originalidade no seu projeto artístico, as primeiras moedas do Real foram produzidas em aço inox, seguindo uma tradição anterior, que resultava na melhor preservação das mesmas. Mesmo assim, seu caráter provisório foi respeitado e em poucos anos o Banco Central resolveu a questão:

\begin{abstract}
"A solução encontrada pelo Banco Central para sanar o problema é a de realizar um concurso aberto à participação de profissionais liberais e empresas de design e comunicação. A ideia do concurso se baseia no argumento de que abrindo à participação de várias vertentes da sociedade, com uma seleção prévia feita por um júri de notáveis e a decisão final sendo tomada por júri popular, o desenho das moedas teria melhor qualidade visual e atenderia aos desejos de representação de nacionalidade de todos os brasileiros" ${ }^{54}$.
\end{abstract}

\footnotetext{
${ }^{52}$ O índice Nacional de Preços ao Consumidor é medido pelo IBGE. Ele é obtido a partir dos Índices de Preços ao Consumidor regionais e tem como objetivo oferecer a variação dos preços no mercado varejista, mostrando, assim, o aumento do custo de vida da população.

53 JUNIOR, Amaury Fernandes. Uma etnografia do dinheiro: os projetos gráficos de papelmoeda no Brasil após 1960. Tese de Doutorado. UERJ. Rio de Janeiro, 2008. p. 263.

${ }^{54}$ Ibidem. p. 263.
} 
Desta maneira surge a $2^{\text {a }}$ família do Real. Segundo a lógica da Casa da Moeda, eles buscaram representar na nova coleção o que melhor representasse a constituição do imaginário histórico-político do país ${ }^{55}$. Assim, foram cunhados seis modelos de moedas que substituíram os seis modelos em aço inox anteriores, embora estes ainda continuassem em circulação.

A moeda de um centavo, produzida até 2004 e hoje fora de circulação, foi elaborada a partir do cobre sobre aço, trazendo a efígie de Pedro Álvares Cabral representando o ato do "Descobrimento". A moeda de cinco centavos, também tem o cobre sobre aço como matéria-prima, e traz a representação messiânica de Tiradentes com símbolos relativos à Conjuração Mineira. Na de dez centavos, a efígie de Dom Pedro I na cena representativa do Grito do Ipiranga, marco da Independência do Brasil, tendo como metal utilizado o bronze sobre aço. $\mathrm{Na}$ de vinte e cinco centavos, a efígie homenageada foi a do Marechal Deodoro da Fonseca junto às Armas Nacionais em referência à Proclamação da República, também em bronze sobre aço. A moeda de cinquenta centavos traz a figura do Barão de Rio Branco e o mapa do Brasil em alusão ao trabalho do diplomata responsável pela configuração geográfica final do território brasileiro. Nestas moedas foram utilizados dois tipos de matéria-prima: incialmente o cuproníquel, e a partir de 2002 o aço inox. O último modelo é a moeda de um Real, elaborada incialmente a partir do cobre e da alpaca ${ }^{56}$ e posteriormente com o níquel e a alpaca. Ela traz a efígie da República, mantendo a tradição de representá-la em moedas desde 1889.

\footnotetext{
${ }^{55}$ Ibidem. p. 265.

${ }^{56}$ A alpaca é uma liga metálica composta por cobre, níquel e zinco.
} 

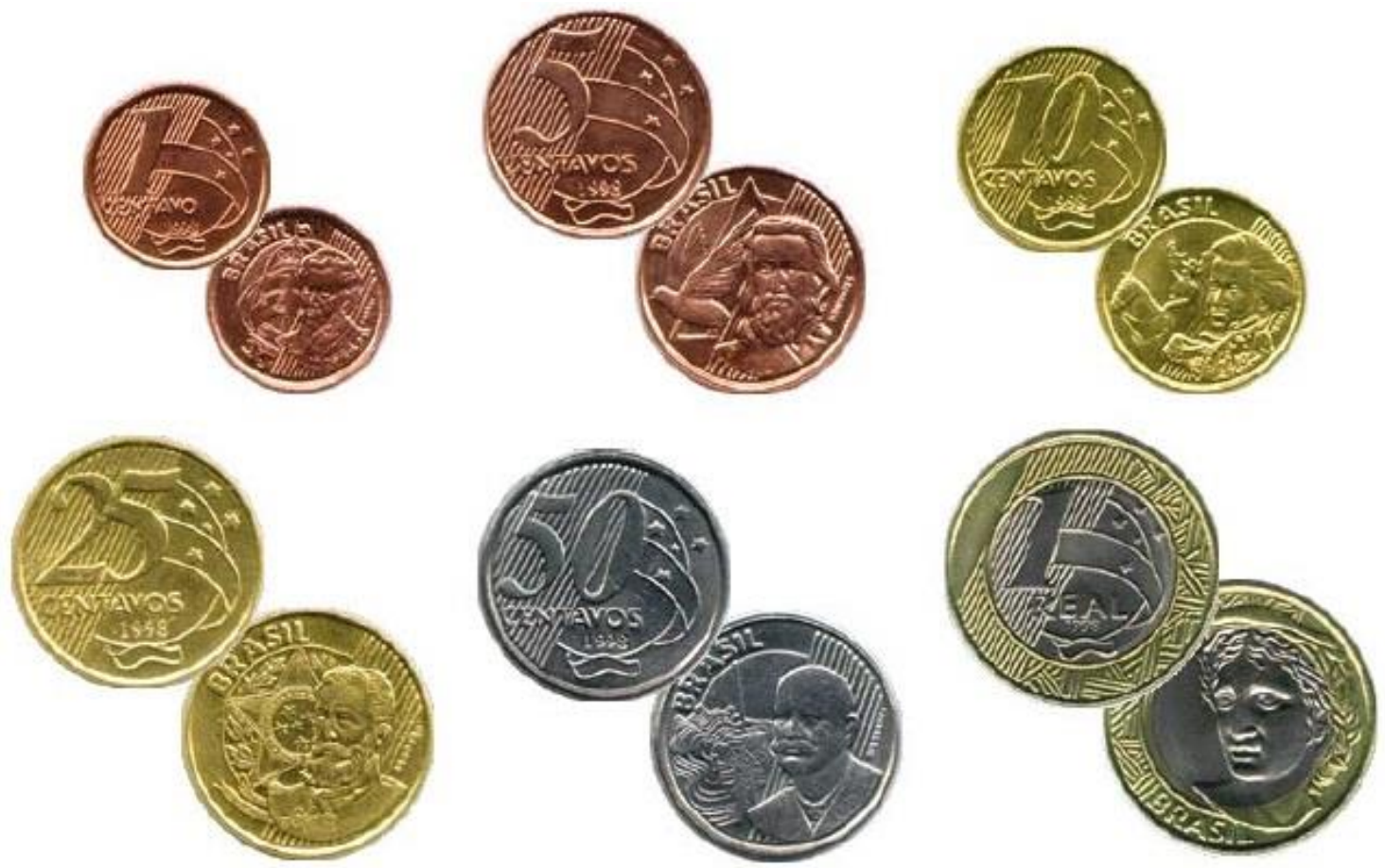

Figura 8 - Moedas da $2^{\mathrm{a}}$ família do Real. Descrição consta no parágrafo anterior.

A escolha da Casa da Moeda por privilegiar na $2^{\mathrm{a}}$ família do Real as efígies que mais representassem a constituição do imaginário histórico-político do país traz uma grande oportunidade de problematização destas fontes em sala de aula. A opção por estes personagens reforça a ideia de uma História oficial da nação e contribui para o debate com os alunos sobre o conceito de sujeitos históricos que vai muito além dos personagens ditos oficiais. A atividade referente a este assunto, bem como a sua aplicação e discussão, encontra-se disponível nesta pesquisa.

Antes de entender a metodologia que se pretende aplicar para o desenvolvimento destas atividades, é preciso fazer uma discussão para o embasamento teórico que um trabalho com moedas requer em sala de aula. Esse debate irá girar em torno da necessidade da fundamentação das estratégias necessárias para o trabalho com fontes históricas no ensino de História, bem como na ideia de conceber o metal-moeda como um patrimônio material. Esta discussão encontra-se no subcapítulo a seguir. 


\subsection{Patrimônio cultural e a educação patrimonial.}

Esta pesquisa leva a refletir sobre a importância de se estimular a prática colecionista e a análise Numismática não somente para despertar o gosto do aluno pelos estudos históricos, mas principalmente para compreender a moeda e sua preservação sob a lógica do patrimônio cultural. Para melhor compreender a relação estabelecida entre Numismática e patrimônio é preciso aprofundar a reflexão no que se refere à compreensão dos objetos enquanto patrimônio cultural. Uma pesquisa importante neste sentido é a de José Reginaldo Santos Gonçalves ${ }^{57}$. Em seu trabalho o autor vai analisar esta relação entendendo a categoria patrimônio como classificadora dos objetos atuando na mediação das ideias e identidades dos grupos sociais.

' $\mathrm{Na}$ medida em que assim classificados e coletivamente reconhecidos, esses objetos desempenham uma função social e simbólica de mediação entre o passado, o presente e o futuro do grupo, assegurando a sua continuidade no tempo e sua integridade no espaço" ${ }^{\text {58 }}$.

Logo, os objetos sendo classificados e definidos como patrimônios culturais “estão por sua vez a nos 'inventar', uma vez que eles materializam uma teia de categorias de pensamento por meio das quais nos percebemos individual e coletivamente", 59 . Com isso, antes de aprofundar esta questão é preciso entender o conceito de patrimônio, e como ele tem mudado ao longo do tempo a partir de novas abordagens.

Segundo consulta ao website do Instituto do Patrimônio Histórico Artístico Nacional (Iphan), o Decreto-lei $n^{\circ}$ 25, de 30 de novembro de 1937 estabelece como patrimônio:

“o conjunto de bens móveis e imóveis existentes no País e cuja conservação seja de interesse público, quer por sua vinculação a fatos memoráveis da história do Brasil, quer por seu excepcional valor arqueológico ou etnográfico, bibliográfico ou

\footnotetext{
${ }^{57}$ GONÇALVES, José Reginaldo Santos. Teorias Antropológicas e Objetos Materiais. In: Antropologia dos objetos: coleções, museus e patrimônio. Rio de Janeiro, 2007. p. 14.

${ }^{58}$ Ibidem p. 28.

${ }^{59}$ Ibidem p. 29.
} 
artístico", o Artigo 216 da Constituição conceitua patrimônio cultural como sendo os bens "de natureza material e imaterial, tomados individualmente ou em conjunto, portadores de referência à identidade, à ação, à memória dos diferentes grupos formadores da sociedade brasileira" ${ }^{\prime \prime 0}$.

Com a Constituição Federal de 1988, o conceito de patrimônio foi ampliado, em seu Artigo 216, incorporando:

"O conceito de referência cultural e a definição dos bens passíveis de reconhecimento, sobretudo os de caráter imaterial. A Constituição estabelece ainda a parceria entre o poder público e as comunidades para a promoção e proteção do Patrimônio Cultural Brasileiro, no entanto mantém a gestão do patrimônio e da documentação relativa aos bens sob responsabilidade da administração pública" ${ }^{\prime 61}$

Segundo o IPHAN, nesta nova definição atribuída pela CF de 1988, estão as formas de expressão, fazer e viver; as criações científicas, artísticas e tecnológicas; as obras. Objetos, documentos, edificações e demais espaços destinados às manifestações artístico-culturais; os conjuntos urbanos e sítios de valor histórico, paisagístico, artístico, arqueológico, paleontológico, ecológico e científico $^{62}$. E assim, dentro destas definições se enquadram obviamente os trabalhos realizados com a numismática no âmbito desta pesquisa.

Dentro desta lógica, pretende-se aqui utilizar um dos objetivos gerais dos PCN's que versa sobre o desenvolvimento de atividades que proporcionem o conhecimento de características fundamentais do Brasil nas dimensões sociais, materiais e culturais como meio para construir progressivamente a noção de identidade nacional e pessoal e o sentimento de pertencimento ao país; o conhecimento e valorização da pluralidade do patrimônio sociocultural brasileiro, bem como saber utilizar diferentes fontes de informação e recursos tecnológicos para adquirir e construir conhecimentos ${ }^{63}$.

\footnotetext{
${ }^{60}$ Website IPHAN http://portal.iphan.gov.br/pagina/detalhes/218 acesso em: 16 de novembro de 2018

${ }^{61}$ Ibidem.

${ }^{62}$ Ibidem.

${ }^{63}$ BRASIL. Parâmetros curriculares nacionais: história/Secretaria de Educação Fundamental. Brasília : MEC /SEF, 1998. p. 5.
} 
Embora a proposta do PCN seja importante ela não deve ser restrita a isso. Como destaca Meneses ao mencionar que "a nação, por exemplo, há muito deixou de ser lugar essencial da memória, pois não atende à heterogeneidade, às oposições, conflitos, mas antes, a um ideal de harmonia no corpo político que nos parece fora de moda ${ }^{964}$. Por isso, é preciso estimular mais além, como fazer o aluno refletir sobre as conexões culturais com outros países, e trabalhar sob uma perspectiva crítica a partir da ideia da identidade nacional. Problematizar esta questão é compreender a existência de outras referências identitárias que devem ser consideradas.

Seguindo estas instruções optou-se por desenvolver atividades focadas no estudo da numismática com ênfase nas relações da cultura material, fontes e o ensino de História. Desta forma, o objetivo foi o de estimular o conhecimento aprendido na escola com o conhecimento cotidiano do aluno (no caso o uso das moedas) e contribuir para o sentimento de pertencimento ao país onde vivem e contribuindo também com o reforço de laços de identidade a partir de uma concepção pluralizada.

Além disso, com o desenvolvimento de trabalhos em grupo, pretendeu-se estimular o relacionamento interpessoal dos alunos; a boa disciplina, o cuidado com patrimônio material e o respeito aos colegas de classe; o melhor rendimento em atividades pedagógicas; bem como o estímulo a pesquisa e produção de conhecimento, quebrando um modelo de educação tradicional.

Estas propostas estão inseridas no âmbito da Educação Patrimonial que se trata de um processo permanente e sistemático de trabalho educacional centrado no patrimônio cultural como fonte primária de conhecimento e enriquecimento individual e coletivo $^{65}$. A partir da experiência e do contato direto com as evidências e manifestações da cultura, em todos os seus múltiplos aspectos, sentido e significado, Horta argumenta que:

"O trabalho da educação patrimonial busca levar as crianças e adultos a um processo ativo de conhecimento, apropriação e

\footnotetext{
64 MENESES, Ulpiano T. Bezerra de. Memória e Cultura Material: documentos pessoais no espaço público. Estudos Históricos. Rio de Janeiro, v. 11, n. 21, p. 89-104, 1998. p. 99.

65 HORTA, Maria de Lourdes Pereira. GRUNBERG, Evelina. MONTEIRO, Adriane Queiroz. Guia Básico de Educação Patrimonial. Instituto do Patrimônio Histórico e Artístico Nacional, museu Imperial,1999. p. 6.
} 
valorização de sua herança cultural, capacitando-os para um melhor usufruto destes bens e propiciando a geração e a produção de novos conhecimentos, num processo contínuo de criação cultural.",66

Para melhor embasamento, indo além das noções de patrimônio discutidas pelo IPHAN ou não se limitando as colocações da Constituição Federal, esta discussão vai aprofundar a relação entre as questões sobre patrimônio e o ensino de História visando efetivar os objetivos propostos. Para esta reflexão serão utilizados dois trabalhos que tratam do tema: um de Lana Mara de Castro Siman ${ }^{67}$ que vai oferecer contribuições conceituais e metodológicas para orientar a prática educativa de professores de História visando estabelecer um diálogo com outros espaços culturais e buscando novas linguagens e ferramentas para o ensino de História. O outro artigo, escrito por Juçara Mello e Iamara Viana ${ }^{68}$ vai discutir as possibilidades da educação patrimonial para a ampliação da prática docente, destacando as relações entre História e Memória no processo de construção do conhecimento em sala de aula.

Ambos os trabalhos vão ampliar a noção do que é patrimônio bem como difundir novas possibilidades para o trabalho com a educação patrimonial com os alunos. Siman realça a importância do alargamento do conceito. Se antes o patrimônio era restrito apenas ao arquitetônico, com as novas abordagens ele passou a ser mais amplo, abrangendo o patrimônio, documental, arquivístico, bibliográfico, hemerográfico, iconográfico, oral, visual, museológico dentre outros que "atestam a historicidade das sociedades humanas" $" 69$.

Mais do que definir os limites do que é ou não um patrimônio cultural, Viana e Mello vão discutir os sentidos deste conceito, ou seja, vão entender que bens patrimoniais "são definidos a partir das crenças, valores e interesses dos diferentes grupos sociais que, em sua permanente tensão, interagem,

\footnotetext{
${ }^{66}$ Ibidem.

67 SIMAN, Lana Mara de Castro. Práticas culturais e práticas escolares: aproximações e especificidades no ensino de história. Revista História \& Ensino. Londrina, v.9, p.185-204, out. 2013.

68 VIANA, Ilmara da Silva. MELLO, Juçara da Silva Barbosa de. Educação Patrimonial e Ensino de História: Diálogos. Revista encontros. Ano 11. Número 20. 2013.

${ }^{69}$ SIMAN, Lana Mara de Castro. Op. Cit. p. 190.
} 
influenciando-se reciprocamente" ${ }^{\Re 0}$. Portanto, como um elemento com potencial para atribuição das identidades, a definição de patrimônio será de responsabilidade de um tripé composto por instituição políticas, acadêmicas bem como a opinião pública ${ }^{71}$.

As autoras refletem também sobre a necessidade da problematização dos patrimônios, pois caso contrário eles ficam a serviço da legitimação de relações culturais hierarquizadas. Neste contexto, a educação patrimonial surge no sentido de trabalhá-lo como um objeto de sensibilização com desconstruções e reconstruções dentro do ensino de histórica escolar ${ }^{72}$. Sob o ponto de vista metodológico três enfoques são apontados para o uso do patrimônio nas aulas de História: a construção, a desconstrução e a reconstrução.

"No primeiro caso, trata-se da atribuição de sentido para a trajetória de indivíduos e grupos, constituindo identidades orientadoras que funcionam como mecanismo de acesso à percepção de si mesmo enquanto sujeito ativo da história. No segundo, a apreensão da existência de outras possibilidades, igualmente legítimas, de criação cultural, embora, nem sempre apresentadas na forma de narrativas históricas com o mesmo grau de sentido e adesão. Já no terceiro, verifica-se a interseção entre elementos intrínsecos ao código cultural e outros externamente adquiridos, surgindo, a partir de então, algo novo e original num processo sempre dinâmico de criação" ${ }^{73}$.

Uma das possibilidades para a realização deste trabalho pode ser a inserção da educação patrimonial dentro do ensino de História relacionando-a aos conteúdos canônicos de forma dinâmica e eficaz. Segundo as autoras, isto facilitaria o que elas chamam de "pontos de contato com o universo cultural dos alunos", onde a educação patrimonial atuaria relacionando o conteúdo ensinado a realidade vivida pelo discente facilitando o processo de aprendizagem ${ }^{74}$.

Concordando com esta ideia, Siman aponta que para desenvolver o pensamento histórico em criança e adolescentes se faz necessário apropriar-se dos elementos vividos por eles. Segundo a autora:

\footnotetext{
${ }^{70}$ VIANA, Ilmara da Silva. MELLO, Juçara da Silva Barbosa de. Op. Cit. p. 52.

${ }^{71}$ Ibidem.

${ }^{72}$ Ibidem. p. 51 e 52.

${ }^{73}$ Ibidem. p. 58.

${ }^{74}$ Ibidem. p. 50.
} 
'torna-se importante não apenas levar os alunos a identificarem elementos de compreensão de temas históricos nas suas experiências sociais, mas também propiciar-lhes ir além do que a experiência vivida pode revelar identificando, nos testemunhos do passado, elementos de continuidade e de ruptura com o presente" ${ }^{\text {. }}$.

Igual destaque aponta a nova BNCC ao considerar que é fundamental valorizar a experiência dos alunos levando-se em conta a sua realidade social, o universo da comunidade escolar, bem como seus referenciais históricos, sociais e culturais $^{76}$. A partir disso, a BNCC propõe como um de seus procedimentos básicos o desenvolvimento de condições necessárias para que os discentes "compreendam e reflitam sobre os significados da produção, circulação e utilização de documentos (materiais ou imateriais), elaborando críticas sobre formas já consolidadas de registro e de memória, por meio de uma ou várias linguagens $", 77$.

Assim, a nova base estabelece em seu procedimento específico que a tarefa de transformar um sujeito em documento, bem como desvendar a sociedade que o produziu cabe ao sujeito que o analisa.

"O documento, para o historiador, é o campo da produção do conhecimento histórico; portanto, é esta a atividade mais importante a ser desenvolvida com os alunos. Os documentos são portadores de sentido, capazes de sugerir mediações entre o que é visível (pedra, por exemplo) e o que é invisível (amuleto, por exemplo), permitindo ao sujeito formular problemas e colocar em questão a sociedade que os produziu" ${ }^{78}$.

O debate sobre o documento, ou seja, sobre os usos das fontes históricas pelo o historiador requer uma atenção especial. Levar esta preocupação para a sala de aula, fazendo com que os alunos construam o conhecimento histórico a partir

\footnotetext{
75 SIMAN, Lana Mara de Castro. Práticas culturais e práticas escolares: aproximações e especificidades no ensino de história. Revista História \& Ensino. Londrina, v.9, p.185-204, out. 2013. p. 192.

${ }^{76}$ BRASIL. Ministério da Educação. Secretaria da Educação Básica. Base nacional comum curricular. Brasília, DF, 2016. p. 401.

${ }^{77}$ Ibidem. p. 416.

${ }^{78}$ Ibidem. p. 418.
} 
de suas possibilidades é uma preocupação desta pesquisa. Sendo assim, no subcapitulo seguinte será privilegiada uma discussão sobre fontes históricas, bem como seu uso no ensino da História Escolar.

\subsection{O uso das fontes históricas: breve panorama.}

"O que faz de um objeto documento não é, pois, uma carga latente, definida, de informação que ele encerre, pronta para ser extraída, como o sumo de um limão. O documento não tem em si sua própria identidade, provisoriamente indisponível, até que o ósculo metodológico do historiador resgate a Bela Adormecida de seu sono programático. E, pois, a questão do conhecimento que cria o sistema documental. $\mathrm{O}$ historiador não faz o documento falar: é o historiador quem fala e a explicitação de seus critérios e procedimentos é fundamental para definir o alcance de sua fala" 79 .

A questão que envolve a natureza da fonte histórica e seu uso por historiadores ao longo do tempo para a construção do conhecimento histórico passa por constante evolução. Durante o século XIX e ainda no século XX, o processo de construção do conhecimento histórico era produzido sob os moldes da corrente historiográfica conhecida como Escola Metódica. Sob essa historiografia, a História era produzida a partir das informações coletadas de documentos tidos como verdades absolutas, carecendo de qualquer tipo de problematização ${ }^{80}$.

Além do foco quase exclusivo em fontes escritas e oficiais, este tipo de História produzida valorizava as classes dominantes, esquecendo a contribuição das outras camadas sociais ${ }^{81}$. Ao historiador, neste processo, cabia a tarefa de transcrever estas fontes, demostrando seu caráter de verdade, sem questioná-la ou pensar em fontes alternativas.

\footnotetext{
79 MENESES, Ulpiano T. Bezerra de. Memória e Cultura Material: documentos pessoais no espaço público. Estudos Históricos. Rio de Janeiro, v. 11, n. 21, p. 89-104, 1998. p. 95.

${ }^{80}$ CARDOSO, Ciro Flamarion; VAINFAS, Ronaldo. (Orgs.). Domínios da História: ensaios de teoria e metodologia. Rio de Janeiro: Campus, 1997. p. 104

${ }^{81}$ Ibidem.
} 
Por este caminho seguia o ensino de História nesta época, com a preocupação de legitimar e atender aos interesses das elites ${ }^{82}$. A História era ensinada como um conjunto de fatos, exaltando-se grandes nomes, heróis da nação e datas. A fonte histórica, predominantemente escrita, servia para comprovar ao aluno o que era ensinado. Estes documentos, por sua vez, eram quase sempre registros oficiais escritos.

Com a criação da escola dos Annales em sua primeira geração, a partir de 1929, muda-se o olhar dos historiadores sobre as fontes. Os documentos oficiais deixam de ser considerados como verdade absoluta, e cabe ao pesquisador a responsabilidade de questioná- $\operatorname{los}^{83}$. Assim, o processo de produção do conhecimento histórico passa a ser controlado pelo historiador que deixa de apenas transcrever estes documentos.

A formulação da Nova História Cultural propicia uma revolução sob a ótica documental. Ela amplia a noção de documento bem como a forma de análise do historiador ${ }^{84}$. As fontes documentais então se tornam qualquer vestígio deixado ou produzido pela sociedade. Todo documento agora tem suas possibilidades interpretativas aumentadas e passa ser passível de questionamentos, acabando com a ideia da verdade absoluta das fontes de outrora, movimento iniciado pela primeira geração dos Annales.

Sobre esta relação, Le Goff avalia que:

“O documento não é inócuo. É, antes de mais nada, o resultado de uma montagem consciente ou inconsciente, da história, da época, da sociedade que o produziram, mas também das épocas sucessivas durante os quais continuou a ser manipulado, ainda que pelo silêncio. $O$ documento é uma coisa que fica, que dura, e o testemunho, que traz devem ser em primeiro lugar analisados desmistificando-lhe seu significado aparente." 85

Seguindo esta linha, acredita-se que a revolução documental proporcionada pela Nova História Cultural deva também ser apropriada dentro da sala de aula.

82 BITTENCOURT, Circe Maria Fernandes. Ensino de história: fundamentos e métodos. $2^{\mathrm{a}}$ edição. Editora Cortez. São Paulo, 2008.

83 BURKE, Peter. A Escola dos Annales (1929-1989): a Revolução Francesa da Historiografia. São Paulo: Fundação Editora da UNESP, 1997. p. 26.

${ }^{84}$ CARDOSO, Ciro Flamarion e VAINFAS, Ronaldo. (Orgs.) Op. Cit. p. 221

85 LE GOFF, Jacques. História e Memória. Tradução de Bernardo Leitão. Campinas, Editora Unicamp, 2003. P. 537-538. 
Por isto defende-se neste trabalho a proposta de fazer o aluno compreender o documento como um registro do passado que necessita ser problematizado aproximando este educando da construção do conhecimento histórico, tornando-o peça central neste processo.

Esta não é uma ideia original. Apesar de muito tempo em descontinuo avanço, com as novas abordagens historiográficas que não eram acompanhadas em sala de aula, este olhar sobre o uso das fontes históricas tem sido privilegiado ultimamente. Em 1998, os Parâmetros Curriculares Nacionais para a disciplina de História trazem a proposta para o trabalho com as fontes históricas em sala se adequando as abordagens historiográficas recentes. Segundo o PCN, o docente deve:

\begin{abstract}
"Desenvolver atividades com diferentes fontes de informação (livros, jornais, revistas, filmes, fotografias, objetos, etc.) e confrontar dados e abordagens; trabalhar com documentos variados como sítios arqueológicos, edificações, plantas urbanas, mapas, instrumentos de trabalho, objetos cerimoniais e rituais, adornos, meios de comunicação, vestimentas, textos, imagens e filmes; ensinar procedimentos de pesquisa, consulta em fontes bibliográficas, organização das informações coletadas, como obter informações de documentos" ${ }^{\prime 86}$.
\end{abstract}

Logo, os procedimentos indicados pelo PCN se adequa a concepção de documento trazido pela geração dos Annales não se restringido apenas as fontes escritas, ou as fontes ditas oficiais. Seguindo o mesmo caminho estão os livros didáticos. Dificilmente exista hoje em dia um manual didático de História que não incentive ou traga sugestões para o uso de fontes históricas em sala de aula pelo professor. Estas sugestões são sempre seguidas dos procedimentos, métodos e técnicas para o uso de determinado material com os alunos, tal como se pretende demonstrar nesta pesquisa com o uso das moedas.

Esta abordagem atual dos livros didáticos não é fruto de iniciativas isoladas dos autores envolvidos na produção destes materiais, e sim uma iniciativa

\footnotetext{
86 BRASIL. Parâmetros curriculares nacionais: história/Secretaria de Educação Fundamental. Brasília : MEC /SEF, 1998. P. 77.
} 
do Ministério da Educação (MEC) que através do Programa Nacional do Livro Didático (PNLD) defendeu o trabalho com documentos nas aulas de História. Por isso o MEC estabeleceu no seu edital de convocação para a produção das novas obras didáticas critérios relativos às propostas metodológicas dos novos livros que seriam distribuídos nas escolas públicas brasileiras ${ }^{87}$. E um destes critérios versa justamente sobre:

“a apresentação e efetiva discussão de fontes históricas, incorporando-as ao texto didático e mobilizando-as para a construção do conhecimento, entendendo tais ações como imprescindíveis para que o livro didático introduza os alunos na metodologia própria da História, levando-os à compreensão de como se produz esse conhecimento" ${ }^{88}$.

Mais recentes são as discussões colocadas pela nova Base Nacional Comum Curricular (BNCC) que ressaltam a importância do uso de fontes históricas para o processo de ensino e aprendizagem em História. Existe na Base uma preocupação em utilizá-las nesse processo. Por isso o uso fontes é considerado um dos três procedimentos básicos para que ocorra a aprendizagem em História nos anos finais do ensino fundamental.

"Para se pensar o ensino de História, é fundamental considerar a utilização de diferentes fontes e tipos de documento (escritos, iconográficos, materiais, imateriais) capazes de facilitar a compreensão da relação tempo e espaço e das relações sociais que os geraram. Os registros e vestígios das mais diversas naturezas (mobiliário, instrumentos de trabalho, música etc.) deixados pelos indivíduos carregam em si mesmos a experiência humana, as formas específicas de produção, consumo e circulação, tanto de objetos quanto de saberes. Nessa dimensão, o objeto histórico transforma-se em exercício, em laboratório da memória voltado para a produção de um saber próprio da História" ${ }^{\$ 9}$.

\footnotetext{
87 CAIMI, Flávia Eloísa. Fontes históricas na sala de aula: uma possibilidade de produção de conhecimento histórico escolar? Anos 90, Porto Alegre, v. 15, n. 28, p. 129-150, dez. 2008. p. 142.

${ }^{88}$ Ibidem.

${ }^{89}$ BRASIL. Ministério da Educação. Secretaria da Educação Básica. Base nacional comum curricular. Brasília, DF, 2016. p. 398.
} 
Por último ainda há de se destacar a iniciativa, a partir de 2016, do Mestrado Profissional em Ensino de História (PROFHISTÓRIA), programa onde está inserida esta pesquisa. Mais do que o estabelecimento de procedimentos específicos ou de propostas curriculares como fizeram os PCN's e a nova BNCC, o PROFHISTÓRIA é responsável por proporcionar a difusão contínua de pesquisas em nível nacional na área de ensino de História a partir do trabalho de professores inseridos na educação básica em escolas brasileiras.

Em uma de suas três linhas de pesquisa intitulada "Linguagens e Narrativas Históricas: produção e difusão", o programa propõe:

"estudos sobre a questão da linguagem e da narrativa histórica, considerando diferentes tipos de suportes, tais como livros, filmes, programas televisivos, sítios da Internet, mapas, fotografias etc. A partir da problematização do uso da linguagem, o objetivo é produzir materiais destinados ao uso educativo, considerando também as possibilidades de difusão científica da História" ${ }^{90}$.

Nesta linha, inúmeros trabalhos desenvolvidos por professores pesquisadores dentro do PROFHISTÓRIA têm buscando ampliar os horizontes do processo de ensino e aprendizagem em História através do uso de fontes históricas em sala de aula. Além de possibilitar o desenvolvimento e formação dos professores atuantes neste programa acadêmico, a difusão destas pesquisas pelo território nacional pode trazer resultados positivos para a atuação docente como um todo. E assim, com o desenvolvimento sistemático de novas abordagens e discussões, com o estabelecimento de novos procedimentos e orientações curriculares, o trabalho com fontes com os alunos tem deixado de ser um ato isolado de um ou outro professor para mudar a realidade da disciplina adequando o seu ensino ao que existe de mais novo na historiografia sobre o assunto, como será discutido a seguir.

\footnotetext{
${ }^{90}$ http://www.his.puc-rio.br/pos-graduacao/prof-hist-capes/ Acesso em: 26 de fev. de 2020.
} 


\subsubsection{O uso das fontes em sala de aula: discussão.}

No texto Regimes de historicidade: como se alimentar de narrativas temporais através do ensino de História ${ }^{91}$, Durval Albuquerque Jr amplia a discussão do conceito formulado por François Hartog analisando a questão da narrativa histórica no processo de produção do conhecimento em sala de aula.

Sobre os Regimes de Historicidade, o autor menciona que o ensino de História deve ter a finalidade óbvia de fazer o aluno realizar a experiência de ir para fora de seu tempo e que cabe ao professor escolher como será feito esse percurso, qual ordenação de tempo utilizar, sua distribuição, sentido e significado $^{92}$. Para isso é necessário que o docente deva fazer o uso da narrativa, pois sem ela não existe aula de História.

Corroborando com ideia do autor de que a narrativa é fundamental neste processo de fazer o aluno experimentar outra época, preparando-o para conviver com o diferente e o estranho, nota-se certos limites nas formas pelas quais as narrativas históricas são produzidas, e se faz necessário buscar abordagens diferenciadas com o foco em outras formas de linguagens. Assim, objetivou-se buscar uma alternativa em fontes históricas diversificadas para reproduzir formas de produzir o conhecimento histórico em sala de aula a partir das perspectivas historiográficas atuais. E, antes de tudo, pretendeu-se aplicar o rigor cientifico a esta relação, pois entende-se que ensino e pesquisa, mesmo nos bancos escolares, não devem ser vistos de maneira dissociada.

A partir desta visão, proporcionar a construção do conhecimento em sala leva a uma reflexão de maior amplitude no sentido de compreender este trabalho sob a lógica da produção do conhecimento científico. Knauss defende que a aprendizagem na educação básica pode ser caracterizada como "uma iniciação científica colocando no centro de suas preocupações as diferentes bases lógicas da construção do conhecimento científico" ${ }^{93}$.

\footnotetext{
${ }^{91}$ ALBUQUERQUE Jr, D.M. de. Regimes de historicidade: como se alimentar de narrativas temporais através do ensino de História, IN: GABRIEL, C.T.;MONTEIRO, A.M.; MARTINS M.B. Narrativas do Rio de Janeiro nas aulas de História. Rio de Janeiro: Mauad X , 2016.(1942).

92 Ibidem.

${ }^{93}$ KNAUSS, Paulo. O Desafio da Ciência: modelos científicos no ensino de história. Cad. Cedes, Campinas, vol. 25, nº 67 , p. 279-295, set./dez. 2005. p. 280.
} 
Criticando um modelo de ensino e aprendizagem baseado predominantemente no ato de repetir e reproduzir pelos alunos, o autor estende esta crítica à prática docente que não valoriza as bases do conhecimento científico $^{94}$. Isso se deve muito em função inclusive do processo que levou a constituição da História como disciplina ensinável ao longo do tempo onde a lógica do conhecimento científico contemporâneo foi posto de lado.

Essa lógica baseia-se na concepção de que o modelo de ciência atual enfatiza "a dedução, salientando a importância da demonstração lógica, baseada na ordem probabilística, ressaltando o indeterminismo, a fim de elaborar leis relativas, condicionadas pela variabilidade das condições dos fatos"95. Assim, partindo destes princípios a pesquisa buscará pensar um modelo de ensino aproximado à lógica científica fazendo professores e alunos se perceberem como difusores deste modelo.

Ao professor, cabe perceber que é preciso se basear em um ensino de História de caráter mais investigativo, a partir de uma proposta metodológica apurada e se baseando em pressupostos teóricos modernos da historiografia, tal como se pretendeu fazer neste trabalho. E mais, é importante também fazer o aluno compreender esta lógica de construção do conhecimento histórico a partir de bases cientificas colocando-o a par de todos os fundamentos e métodos aplicados nas atividades que serão desenvolvidas.

Desenvolver esta lógica de trabalho resulta, como destaca Knauss, na autonomia do ensino:

"em relação ao saber acadêmico ao permitir-se explorar os diferentes modelos científicos e não se comprometendo com a exclusividade de uma lógica explicativa (o que pode ser caracterizado como próprio do saber acadêmico e que caracteriza a marca autoral de um grupo de pesquisa ou pesquisador). Em segundo lugar, tomar a diversidade científica como referência para o ensino e a aprendizagem permite redefinir a prática da pesquisa na sala de aula, indo além da caricatura ou da caça a fatos. Interrogar a ciência como construção intelectual e interpretativa configura a pesquisa como princípio educativo que promove o sujeito do

\footnotetext{
${ }^{94}$ Ibidem. p. 281.

${ }^{95}$ Ibidem. p. 283.
} 
conhecimento e deixa a ciência ao alcance dos que movem o pensamento" 96 .

Visando este propósito, aqui foi feita uma seleção de artigos acadêmicos onde os autores se debruçaram sobre a temática do trabalho com fontes históricas em sala de aula. Não se tratou apenas de expor pesquisas significativas isoladamente, mas entende-las como um todo através da articulação das ideias discutidas pelos autores a fim de estabelecer uma base teórica sólida cujas atividades propostas por esta pesquisa irão se apoiar.

Dos artigos selecionados tem-se o trabalho de Nilton Mullet Pereira e Fernando Seffner intitulado $O$ que pode o ensino de história? Sobre o uso de fontes na sala de aula ${ }^{97}$, que vai discutir o uso das fontes levando-se em conta a concepção ampla em que os documentos históricos têm sido analisados ultimamente. Assim, discutirão a viabilidade do uso destas fontes em sala como uma alternativa pedagógica da mesma forma que os historiadores a utilizam em suas pesquisas, ou seja, levando-se em conta a questão da crítica ao documento.

Os autores partem do princípio que o uso de fontes no ensino de História pode ser uma estratégia adequada e produtiva para a sala de aula. A ideia deste estudo não é pensar os alunos como historiadores, mas para que a História faça a diferença na compreensão do mundo em que vivem a partir do manejo de fontes no ambiente escolar.

O outro artigo utilizado foi escrito por Marieta Pinheiro de Carvalho e Vivian da Silva Zampa com o título O Arquivo Nacional na "Sala de Aula': fontes históricas na construção do conhecimento ${ }^{98}$. Neste trabalho as autoras têm o propósito de analisar o uso das fontes históricas como um recurso pedagógico em sala a partir da proposição de uma atividade prática. No caso, o recorte feito foi o uso do acervo de História colonial do Arquivo Nacional no intuito de redimensionar questões tradicionalmente não aprofundadas sobre o tema e buscando despertar o maior interesse dos alunos para as aulas de História.

\footnotetext{
${ }^{96}$ Ibidem. p. 293.

${ }^{97}$ PEREIRA, N. M. e SEFFNER, F. O que pode o ens ino de história? Sobre o uso de fontes na sala de aula. Anos 90, Porto Alegre, v. 15, n. 28, p.113-128, dez. 2008.

98 CARVALHO, M. P. de. e ZAMPA, V. C. da S. O Arquivo Nacional na "Sala de Aula": fontes históricas na construção do conhecimento. Revista História Hoje, v. 6, n 12, p. 35-54 - 2017.
} 
Elas vão ressaltar que em atividades como tal, as relações do ensino de História com a problematização a partir da análise de fontes pelos alunos proporcionam uma participação mais ativa do educando no processo de produção de conhecimento histórico. Isso é fazer o aluno peça central neste processo e do professor um mediador, e não um reprodutor do conhecimento.

Também foi selecionado o artigo de Flávia Eloísa Caimi intitulado Fontes históricas na sala de aula: uma possibilidade de produção de conhecimento histórico hiscolar $?^{99}$. Neste trabalho a autora discute as possibilidades do uso de fontes em sala de aula como forma superar o "conteudismo/verbalismo" das aulas, bem como o uso delas para produzir o conhecimento histórico. Ela vai analisar também como as propostas dos PCNs e o Programa Nacional do Livro Didático (PNLD) vão tratar desta questão.

A articulação das ideias destes autores observa o papel do professor no tocante ao uso das fontes. Pretendeu-se perceber como o docente atuará como o mediador no processo de produção do conhecimento. Foi observado como a teoria aliada a metodologia de ensino é preciso ser pensada para um ensino de História transformador, e isso dependerá, antes de tudo, das escolhas do professor.

Sobre isto, Albuquerque Jr salienta que "educar, implica escolhas do que oferecer e de como apresentar o escolhido aos alunos"100. Como apresentar o escolhido ao aluno é tarefa fundamental, pois é partir daí que se dá o processo de compartilhamento de saberes e onde está fundamentado o processo de aprendizagem. Saber como ensinar implica considerar as múltiplas realidades enfrentadas nos diferentes espaços escolares, bem como compreender a heterogeneidade do educando. Além de saber a teoria, é preciso saber como transmiti-la e para isso se faz necessário saber para quem este conhecimento será transmitido, no caso o aluno.

Concordando com Albuquerque Jr, Carvalho e Zampa também defendem o papel de destaque do professor em sala de aula como o profissional que contribui para promover a implementação destas escolhas para a construção do conhecimento histórico ${ }^{101}$. Dentro destas escolhas se encontram o uso de fontes

\footnotetext{
99 CAIMI, Flávia Eloísa. Fontes históricas na sala de aula: uma possibilidade de produção de conhecimento histórico escolar? Anos 90, Porto Alegre, v. 15, n. 28, p. 129-150, dez. 2008.

${ }^{100}$ ALBUQUERQUE Jr, D.M. de. Op. Cit. p.12.

${ }^{101}$ CARVAlHO, M. P. de. e ZAMPA, V. C. da S. Op. Cit. p.36.
} 
históricas diversificadas que contribuem para o desenvolvimento deste processo construtivo. Caimi também aponta esta necessidade da atuação docente no trato com documentos históricos ressaltando que esta tarefa requer competências específicas do professor na organização deste trabalho pedagógico ${ }^{102}$.

Quanto às competências necessárias, o PCN destaca as possibilidades da atuação do professor:

"Com o propósito didático, o professor pode solicitar suas primeiras impressões, instigá-los no questionamento, confrontar com informações divergentes, destacar detalhes, socializar observações e criar um momento para que possam comparar suas ideias iniciais com as novas interpretações conquistadas ao longo do trabalho de análise. Com atenção e perspicácia, podem ser observadas e colhidas informações nos detalhes: fatos, estéticas, conceitos, sentidos etc. É possível pesquisar informações sobre o documento em fontes externas (autoria, contexto da obra, estilo etc.) e confrontar eventos históricos identificados na fonte estudada a eventos de outras épocas, quanto a semelhanças e/ou diferenças e relações de continuidade e/ou descontinuidade. Quando o professor considerar necessário, pode ser feita a pesquisa da trajetória histórica de preservação, conservação e difusão do documento. É importante que o trabalho envolva observações, descrições, análises, pesquisas, relações e interpretações e, no final, aconteça um momento de retorno ao documento, para que os alunos comparem as novas informações - o seu "novo olhar" com suas apreensões iniciais e reflitam sobre problemáticas históricas a ele relacionadas" $" 103$.

Atualmente, a BNCC também trás estas recomendações quanto ao trabalho docente indicando os procedimentos básicos para o trato com as fontes históricas.

"Os procedimentos básicos para o trato com a documentação envolvem: identificação das propriedades do objeto (peso, textura, sabor, cheiro etc.); compreensão dos sentidos que a sociedade atribuiu ao objeto e seus usos (máquina que produz mercadorias, objeto de arte, conhecimento etc.); e utilização e transformações de significado a que o objeto foi exposto ao longo do tempo. Esse exercício permite que os estudantes

${ }^{102}$ CAIMI, Flávia Eloísa. Op. Cit. p. 142.

103 BRASIL. Parâmetros curriculares nacionais: história/Secretaria de Educação Fundamental. Brasília : MEC /SEF, 1998. p. 86-87. 
desenvolvam a capacidade de identificar, interpretar, analisar, criticar e compreender as formas de registro" 104 .

Assim, o estabelecimento de uma teorização e uma metodologia apurada no uso das fontes em sala de aula se faz necessária. Pereira e Seffner defendem que o uso destas fontes não deve ser uma obrigação do professor, e que existe em muitos casos uma ideia fixa para utilizá-las em sala sem se questionar sobre os fundamentos teóricos e metodológicos no seu uso. Eles criticam o fato das fontes serem usadas apenas parar tornar as aulas mais atrativas, e apenas para confirmar o que foi dito pelo professor ${ }^{105}$.

De fato, esta será uma preocupação de muitos autores que se debruçam sobre o trabalho com fontes históricas em sala de aula. Caimi, por exemplo, destaca que:

"na atual compreensão do tema, é imprescindível o trabalho do professor e do aluno na problematização e significação dos documentos, utilizando-os de modo a extrapolar meras funções de ilustração, motivação, informação ou prova, ainda que estas possam ter relativa importância" ${ }^{\prime 106}$.

Carvalho e Zampa destacam este papel das fontes para além do papel comprobatório e ilustrativo a partir da sua problematização. É preciso relacionar o estudo dos documentos históricos à construção do conhecimento ${ }^{107}$. Assim, segundo as autoras, o documento somente ganha uma perspectiva histórica quando ele passa a ser problematizado, e cabe ao professor escolher o momento correto e uma metodologia eficaz para utilizá-los:

"É o docente, em sua prática cotidiana, que saberá o momento adequado para trabalhar com os documentos, decidindo as intenções didáticas e a especificidade da temática histórica estudada. De igual maneira, é preciso que ele estabeleça

\footnotetext{
104 BRASIL. Ministério da Educação. Secretaria da Educação Básica. Base nacional comum curricular. Brasília, DF, 2016. p. 418.

105 PEREIRA, N. M. e SEFFNER, F. Op. Cit.

106 CAIMI, Flávia Eloísa. Fontes históricas na sala de aula: uma possibilidade de produção de conhecimento histórico escolar? Anos 90, Porto Alegre, v. 15, n. 28, p. 129-150, dez. 2008. p.147.

${ }^{107}$ CARvalho, M. P. de. e ZAMPA, V. C. da S. Op. Cit.
} 
"critérios de escolha" a partir de questionamentos que podem orientar a sua atividade." 108

As autoras utilizam os PCNs para estabelecer um roteiro para apoiar o docente no trabalho com documento dividindo este processo em três questões. Primeiramente destacando que é preciso construir em conjunto com os alunos uma análise crítica do documento. Depois, é preciso utilizar esta fonte como ferramenta que permita fazer conexões entre o presente e o passado. E por último a necessidade de fazer uma contextualização, para que o aluno entenda o momento em que foi produzido.

Pereira e Seffner também vão se debruçar sobre essa questão de como fundamentar o uso das fontes e como o uso destas por historiadores podem ser utilizadas também dentro do ambiente escolar. Dentro deste aspecto eles condenam o uso delas como um meio de sustentar o discurso do professor, ou seja, de um tom de realidade sobre a narrativa histórica produzida pelo docente.

Esta concepção não está equivocada, porém ela tira o potencial de problematização que o documento pode oferecer, dando apenas um caráter de validador da verdade. Como visto, dada à evolução da historiografia, este aspecto já foi superado no que tange à revolução documental vivida atualmente, e uma análise de fontes mais pormenorizada deve ser priorizada. Assim, Pereira e Seffner afirmam que o "uso de fontes históricas deve servir para suspender o caráter de prova que os documentos assumem desde a História tradicional e mostrar às novas gerações a complexidade da construção do conhecimento histórico". 109

Caimi corrobora esta ideia em seu trabalho destacando as múltiplas possibilidades do trabalho com documentos históricos em sala muito além do seu uso em caráter ilustrativo.

"Mais do que objetos ilustrativos, as fontes são trabalhadas no sentido de desenvolver habilidades de observação, problematização, análise, comparação, formulação de hipóteses, crítica, produção de sínteses, reconhecimento de diferenças e

\footnotetext{
${ }^{108}$ Ibidem. p. 41.

${ }^{109}$ PEREIRA, N. M. e SEFFNER, F. Op. Cit. p. 126.
} 
semelhanças, enfim, capacidades que favorecem a construção do conhecimento histórico numa perspectiva autônoma" ${ }^{110}$.

Entretanto, outra autora, Circe Bittencourt, referência na área do ensino de História, defende que a fontes podem sim serem utilizadas pelo professor com o caráter de validação do que foi explicado, pois o documento possui função ilustrativa e informativa, bem como pode ser utilizado para a introdução de um tema de estudo ${ }^{111}$. De fato, ao analisar a forma como os livros didáticos utilizam as fontes (além das proposições mencionadas anteriormente), uma delas é a de introduzir um tema de estudo, sempre no início de um capítulo, como já citado manual didático "História, Sociedade e Cidadania"112 ou então com o caráter validador de algum excerto. A autora também salienta quanto ao devido cuidado do professor ao selecionar a fonte adequada para faixa etária evitando problemas de compreensão nos vocabulários ou quanto ao tamanho dos textos, no caso das fontes escritas ${ }^{113}$.

Para uma metodologia que proponha transformar o aluno em sujeito a partir do uso de fontes históricas é fundamental o recurso da problematização e do questionamento, apontam Carvalho e Zampa ${ }^{114}$. Uma destas formas de alcançar este estágio de questionar ou de problematizar um documento é fazer do uso de diversos tipos de fontes.

Por exemplo, um depoimento oral, deve ser problematizado, assim como qualquer tipo de fonte, não deve ser entendido como uma prova concreta, mas tem a sua contribuição para a reconstituição de determinado processo histórico em curso. Para isso, essa fonte precisa também ser confrontada com outros tipos de fontes, pois ela também pode transmitir equívocos se não questionada e problematizada corretamente.

"O confronto de informações contidas em diversas fontes bibliográficas e documentais pode ser decisivo no processo de conquista da autonomia intelectual dos alunos. Pode favorecer

\footnotetext{
${ }^{110}$ CAIMI, Flávia Eloísa. Op. Cit. p. 141.

${ }^{111}$ BITTENCOURT, Circe. Ensino de História: fundamentos e métodos. $4^{a}$. ed. São Paulo: Cortez, 2011. p. 30.

112 BOULOS JUNIOR, Alfredo. História: sociedade e cidadania , 9ªno. São Paulo: FTD, 2016.

113 BITTEnCOURT, Circe. Op. Cit.

${ }^{114}$ CARvalho, M. P. de. e ZAMPA, V. C. da S. Op. Cit.
} 
situações para que expressem suas próprias compreensões e opiniões sobre os assuntos, investiguem outras possibilidades de explicação para os acontecimentos estudados, considerem a autoria das obras e seus contextos de produção, realizem entrevistas, levantamentos e organizações de dados, pesquisem em bibliotecas e museus e, além disso, observem, comparem e analisem espaços públicos e privados." 115

Em trabalhos assim, Carvalho e Zampa ressaltam que o professor deve estar atento que determinado tipo de fonte apenas apresentam algumas marcas do passado, e que não dão conta de tratar determinado período histórico como um todo ${ }^{116}$. Para isso, esses documentos precisam ser complementados e confrontados com outros tipos de fontes, citando exemplos como jornais, pinturas, telas e músicas como exemplo.

A partir destas abordagens, os alunos conseguem compreender as diferentes representações sobre o passado. Segundo Pereira e Seffner:

\begin{abstract}
"Ensinar utilizando fontes não quer dizer ensinar a produzir representações através das fontes, mas ensinar como os historiadores produzem conhecimento sobre o passado a partir das fontes disponíveis e quais os problemas implicados nessa produção. Pretendemos, desse modo, ensinar aos estudantes a especificidade da narrativa histórica em relação a outras narrativas do passado, como o cinema, a televisão, a literatura, a música, a matéria jornalística, dentre outras. Ou seja, queremos que o estudante se torne alguém capaz de reconhecer na História o estatuto de uma ciência, com seus limites e suas possibilidades" $" 117$.
\end{abstract}

Apesar de todos os avanços no sentido de proporcionar ao ensino de História o que há de mais recente nas abordagens historiográficas no manejo de fontes em sala de aula, ainda é preciso um esforço maior para que tal prática seja enraizada na atuação docente. Assim, com o intuito de colocar em prática toda a teorização aqui apresentada, baseada desde os preceitos iniciais dos PCNs até os procedimentos atuais colocados pela nova BNCC, somado a articulação das ideias

\footnotetext{
115 BRASIL. Parâmetros curriculares nacionais: história/Secretaria de Educação Fundamental. Brasilia : MEC /SEF, 1998. p. 65.

${ }^{116}$ CARVAlHO, M. P. de. e ZAMPA, V. C. da S. Op. Cit.

${ }^{117}$ PEREIRA, N. M. e SEFFNER, F. Op. Cit.
} 
dos autores aqui selecionados, foi realizado um esforço de não apenas fazer com que este trabalho fosse reflexo de uma experiência isolada, mas o resultado de um processo que envolveu o levantamento de questões que, surgidas da prática docente imersa no ambiente escolar e refletidas teoricamente no ambiente acadêmico, retornaram como conhecimentos para aplicação prática, na forma de experiências de aprendizagem em sala de aula.

O próximo capítulo apresentará esta tentativa, a partir do estabelecimento de uma metodologia para o trabalho com a numismática em sala de aula. 


\section{Metodologia aplicada ao uso da numismática para o ensino e aprendizagem de História na educação básica.}

Antes de descrever a metodologia de todas as atividades desenvolvidas, este capítulo objetiva, também, expor uma orientação de ordem técnica e metodológica para o trabalho com a numismática. São abordadas questões como o cuidado com a guarda e limpeza do material, ensinamentos técnicos para a análise de uma moeda, além da busca pelo apoio de novas tecnologias para o estudo da mesma. Visou-se uma linguagem mais didática nesta abordagem, pois buscou-se atender tanto ao professor que tenha pouco conhecimento sobre o assunto, quanto a necessidade de não perder de vista o aluno como o centro da construção deste projeto.

Inicialmente, foi feita uma breve descrição do munícipio, da escola e das turmas onde as atividades foram desenvolvidas. É importante o destaque a estes elementos, pois todos podem refletir nos resultados obtidos, dado a heterogeneidade dos alunos, das escolas, bem como o bairro, região ou cidade onde eles se encontram. Assim, se faz necessário pensar em todas as variáveis na hora da analisar os resultados.

\subsection{O município e a escola.}

As atividades foram aplicadas em turmas de anos finais do ensino fundamental regular de escolas da rede municipal de Quatis. A cidade está situada ao sul do estado do Rio de Janeiro, na região do Médio Vale do Paraiba, próximo à divisa com o estado de São Paulo.

No passado a região foi ocupada inicialmente pelos indígenas Puris ${ }^{118}$, passando por um período de quase três séculos sem a ocupação dos colonizadores, servindo apenas de rota de passagem para tropeiros que seguiam rumo às Minas

\footnotetext{
${ }^{118}$ KNIVET, Anthony. As incríveis aventuras e estranhos infortúnios de Anthony Knivet (1591). Organização, introdução e notas: Sheila Moura Hue. Rio de Janeiro: Jorge Zahar, 2007.
} 
Gerais e de lá retornavam ${ }^{119}$. Seu auge econômico começa em finais do século XVIII com a economia cafeeira e o surgimento de extensas propriedades destinadas ao cultivo do café. Vestígios desta época são os grandes casarões situados na zona rural que outrora serviram para abrigar os Barões de café, bem como a comunidade quilombola de Santana, cuja população recebera porções de terra no pós-abolição, resistindo até os dias de hoje através das novas gerações que vêm mantendo suas tradições culturais de matriz africana ${ }^{120}$.

Atualmente possui uma população estimada de 14.302 habitantes segundo o IBGE $^{121}$. A cidade apresenta característica bucólica típica de cidades interioranas. Possui praça com coreto e uma Igreja da Matriz, uma estação de trem, hoje abandonada, datada de finais do século XIX, e uma fonte de água mineral que serve para o consumo de grande parte da população que leva seus galões para abastecê-los. Diz-se na letra do hino de Quatis que quem bebe água da fonte fica preso na cidade até morrer.

Os eventos culturais do município estão na maioria das vezes ligados as festas promovidas pela Igreja Católica, onde se destaca a festa da padroeira da cidade, Nossa Senhora do Rosário. Existe também a festa promovida pela $\mathrm{APAE}^{122}$, onde a música sertaneja é seu ponto forte, bem como um torneiro leiteiro no distrito de São Joaquim. Todo segundo e quarto domingo do mês ocorre uma feira da roça na cidade, onde produtores rurais locais vendem seus produtos, além de ocorrerem apresentações de música caipira. Outros eventos promovidos pela prefeitura ou por cidadãos são realizados na praça da cidade ao longo do ano, como apresentações da fanfarra, rodas de choro e samba e feiras de artesanato.

A zona rural tem como principais atividades econômicas a agricultura e a pecuária $^{123}$, onde se destaca a produção leiteira e o gado de corte ${ }^{124}$. Na zona urbana, destaca-se o setor de serviços e o comércio. Na falta de grandes empresas

\footnotetext{
${ }^{119}$ http://quatis.rj.gov.br/historia/ Acesso em: 13 de nov. de 2019.

${ }^{120}$ ALVES, Aline Neves Rodrigues. Comunidade Quilombo de Santana. Belo Horizonte: FAFICH, 2016.

${ }^{121}$ https://cidades.ibge.gov.br/brasil/rj/quatis/panorama Acesso em: 09 de out. de 2019.

${ }^{122}$ Associação de Pais e Amigos dos Excepcionais.

${ }^{123}$ https://cidades.ibge.gov.br/brasil/rj/quatis/pesquisa/23/22957?detalhes=true Acesso em: 13 de nov. de 2019.

${ }^{124}$ Produção bovina destinada ao consumo da carne.
} 
empregadoras, o principal empregador do município é a prefeitura, que mantém um quadro consistente de profissionais estatutários, além de uma parcela de cargos comissionados ${ }^{125}$.

A escola onde as atividades foram realizadas é o CIEP 492 Municipalizado Marciana Machado d'Elias, situada no Bairro Santo Antônio, zona urbana do município de Quatis. A Escola atende os alunos da comunidade do entorno bem como alunos provenientes da zona rural do munícipio. É oferecido ensino básico em nível de educação infantil e ensino fundamental tanto dos anos iniciais quanto dos anos finais ( $6^{\circ}$ ao $9^{\circ}$ ano), foco deste trabalho, para quase mil alunos em dois turnos, matutino e vespertino. Para atender a tantos alunos, a escola conta com cento e dez funcionários divididos entre professores, secretaria, inspetores, equipe diretiva, orientação educacional e pedagógica, atendimento educacional especializado, cozinha, limpeza e serviços gerais. Conta também com auxilio da guarda municipal que faz a segurança patrimonial da escola $24 \mathrm{~h}$ por dia.

O espaço físico é estrutura padrão dos CIEPs. A escola é composta por duas edificações, uma destinada ao ensino fundamental e a outra a educação infantil. Compõem a estrutura física 20 salas de aula, sala de diretoria, sala de professores, laboratório de informática em desuso (utilizada como sala de projeção de vídeos em Datashow), sala de recursos multifuncionais para Atendimento Educacional Especializado (AEE), quadra de esportes coberta, cozinha, biblioteca, sala de leitura, banheiros dentro e fora do prédio, dependências e vias adequadas a alunos com deficiência ou mobilidade reduzida, sala de secretaria, refeitório, despensa, almoxarifado, pátio coberto, pátio descoberto, área verde e estacionamento para os funcionários.

O alunado sob a ótica socioeconômica não apresenta muita distinção, visto que a escola atende grande parte da comunidade carente no seu entorno. Embora a cidade seja pequena, nesta localidade registra-se a presença do narcotráfico (em proporções menores ao visto nos grandes centros urbanos) e com frequência há relatos de ex-alunos que se envolvem neste tipo de atividade. Felizmente, a presença do tráfico de drogas não é presente na escola, bem como é pequeno o envolvimento dos adolescentes em idade escolar junto ao mesmo. No entanto

\footnotetext{
${ }^{125}$ http://transparencia.quatis .rj.gov.br/ Acesso em: 13 de nov. de 2019.
} 
reproduz-se por parte de alguns alunos o discurso sobre criminalidade envolvendo principalmente facções criminosas.

Outra característica de parte do alunado são os oriundos da zona rural. Em localidades que não são atendidas por escolas do campo (no município são três) os jovens são redirecionados para escolas da zona urbana. Muitos acordam cedo para chegar à escola devido as grandes distâncias, agravadas pelo estado precário das estradas, ainda sem qualquer tipo de pavimentação. Alguns relatam despertar às 4h30 da manhã para chegar ao início da aula às $7 \mathrm{~h}$.

Em casos em que os alunos perdem o transporte escolar por este passar muito cedo, ou em caso de fortes chuvas que fecham os acessos destas localidades distantes, os alunos são impossibilitados de frequentar a escola. Já houve relatos de estudantes que caminham quilômetros até chegar à escola, atravessando pastos e áreas pantanosas, muito em função de não acarretar na perda do benefício social do governo federal que estabelece uma frequência mínima de $85 \%$ do aluno na escola. É comum estes alunos trabalharem no contra turno, principalmente ajudando a familia na lavoura ou na ordenha de vacas. Os alunos provenientes dessas regiões, apesar de serem, em sua maioria, muito respeitosos e calmos apresentam grande dificuldade na aprendizagem ${ }^{126}$.

\subsubsection{As turmas envolvidas.}

As atividades foram aplicadas em turmas dos anos finais do ensino fundamental, do $6^{\circ}$ ao $9^{\circ}$, durante o segundo semestre de 2019 e o primeiro semestre de 2020. As turmas escolhidas para as atividades seguiram o critério de enquadramento do conteúdo programático alinhado à proposta de atividade com o uso da numismática. Aqui, se compartilha da visão de Mello e Viana ${ }^{127}$ ao inserir

\footnotetext{
126 As informações referentes à escola foram obtidas a partir da observação dos dados e de entrevista com a equipe diretiva. Até o momento da escrita desta dissertação a escola não possuía um Projeto Político Pedagógico para consulta de informações pertinentes.

${ }^{127}$ Mello e Viana argumentam que em uma realidade onde a carga horária reservada à disciplina História já se apresenta reduzida, faz-se necessário elaborar formas dinâmicas e eficazes de relacionar a educação patrimonial aos conteúdos canônicos. Ver MELLO, Juçara da Silva Barbosa de. VIANA, Ilmara da Silva. Educação Patrimonial e Ensino de História: Diálogos. Revista encontros. Ano 11. Número 20. 2013. p. 50.
} 
estas atividades dentro dos conteúdos canônicos da História escolar de forma a dinamizá-los.

Isso quer dizer que como foi feito o recorte para o ensino de História do Brasil República a partir de sua proclamação, as turmas do $8^{\circ}$ e $9^{\circ}$ ano foram privilegiadas neste contexto. Com exceção apenas para as turmas de $6^{\circ}$ ano que foram escolhidas para participar da atividade sobre os sujeitos históricos, tema que já deve ser introduzido nesta série de acordo com o programa de História no contexto da nova BNCC. Sendo assim, os trabalhos foram realizados com as turmas 603, 801 e 901 no segundo semestre do ano de 2019, e 601, 603, 901 e 902 no primeiro semestre de 2020.

A proposta de aplicar as atividades em turmas diferentes, repetidas vezes e em momentos distintos do ano letivo baseia-se na ideia discutida no primeiro capítulo de alinhar o ensino de História às diferentes bases lógicas do conhecimento científico. Sendo assim, se faz necessário testar as hipóteses propostas nestas variadas condições a fim de "elaborar leis relativas, condicionadas pela variabilidade das condições dos fatos"128, como destacou Knauss.

\subsection{As fontes utilizadas.}

O acervo numismático utilizado para a análise dos alunos nesta pesquisa trata-se de coleção própria formada desde a infância a partir de duas moedas presenteadas por meu pai. A partir de então o gosto pelo colecionismo foi se desenvolvendo e após receber, já na adolescência, como herança de meu avô centenas de moedas brasileiras do período monárquico e republicano resolvi me debruçar sobre a numismática. A coleção ganhou mais corpo com o tempo, a partir da compra de novas peças em antiquários e feiras especializadas, com a troca com outros colecionadores, e com o câmbio em viagens.

Hoje a coleção se divide em duas partes: uma de moedas internacionais constando itens de países visitados como Pesos uruguaios, argentinos, chilenos, colombianos e mexicanos; Nuevo Sol Peruano, Balboa panamenho, Quetzal

\footnotetext{
${ }^{128}$ KNAUSS, Paulo. O Desafio da Ciência: modelos científicos no ensin o de história. Cad. Cedes, Campinas, vol. 25, nº.67, p. 279-295, set./dez. 2005. p. 280.
} 
guatemalteco, dólar belizenho, americano e canadense; além de moedas da zona do Euro. A outra parte da coleção é formada por moedas brasileiras, das quais constam dezesseis do período monárquico, sendo algumas raras, e as demais do período republicano. Das moedas republicanas não se sabe exatamente a quantidade exata de peças, pois grande parte destas ainda não foi catalogada, no entanto avalio que o número de itens seja de aproximadamente duas mil unidades.

Isso ajuda a compreender a escolha do recorte temporal para o trabalho com os alunos devido à quantidade de fontes disponíveis, como explicado no primeiro capítulo. Sendo assim, as moedas selecionadas para as atividades foram as que compreendem todo o período republicano brasileiro, bem como as do final da monarquia que serão usadas especificamente em uma atividade para entender os significados da passagem do Império para a República.

\subsection{Conservação, limpeza e acondicionamento das moedas.}

As questões relativas ao patrimônio cultural discutidas no capítulo anterior revelam a necessidade de promover a sua preservação. Logo, o trabalho com a numismática em sala de aula pode ser uma oportunidade para fazer os alunos entenderem a importância do cuidado com todo tipo de patrimônio. Assim, pretende-se, através de atividades práticas, demonstrar a importância da conservação, da limpeza e do acondicionamento das moedas.

A partir do estudo de Vieira ${ }^{129}$ sobre a conservação de moedas, têm-se inicialmente três dicas fundamentais para a preservação destas fontes: primeiro, as moedas precisam ser limpas após o seu manuseio; segundo, jamais acondicionar conjuntamente moedas feitas a partir de metais diferentes; e por último, evitar que as moedas fiquem expostas por muito tempo ao ar e a umidade. Entender a razão para estas dicas é importante e uma ótima possibilidade para o desenvolvimento de um trabalho interdisciplinar com a disciplina de química, pois ela facilita na compreensão de alguns conceitos expostos a seguir.

\footnotetext{
${ }^{129}$ VIEIRA R. M. L. Alguns princípios gerais de conservação de moedas e o processo de limpeza mecânica adotado no Museu Histórico Nacional. Rev. do Museu de Arqueologia e Etnologia, São Paulo, 2:133-136, 1992.
} 
Sabe-se que as moedas brasileiras do período republicano são todas feitas de metais de diferentes tipos. Sendo assim, estão sujeitas a reação química que ocorre comumente em metais chamada de corrosão. A corrosão é um processo que pode destruir totalmente ou parcialmente um objeto sendo causado pela ação do meio.

Uma das formas que o processo de corrosão nas moedas ocorre é no seu contato com o ar e a umidade devido à ação da água e do oxigênio. $\mathrm{O}$ contato destas substâncias com o metal é chamado de corrosão eletroquímica, formando a conhecida oxidação do metal, que o deixa com um aspecto avermelhado e sujo. Da mesma forma, deve-se evitar o contato das fontes com a poeira, bem como guardá-la em conjunto com moedas produzidas com metais diferentes, pois isso igualmente acarreta em um processo de corrosão eletroquímica. Metais diferentes em contato, com a ajuda da umidade e sais, formam eletrólitos fazendo com que uma corrente elétrica circule entre estes metais. O resultado é que o metal menos nobre sofrerá a corrosão e suas partículas serão transportadas para o metal mais nobre danificando-o de igual forma.

Outro tipo de corrosão é a corrosão química. Nas moedas ela ocorre geralmente pelo uso de um agente químico, como solventes, que são utilizados no intuito de fazer a sua limpeza. Diferente da corrosão eletroquímica, não necessita da presença da água ou do oxigênio para que a corrosão ocorra, pois não ocorre a transferência eletrolítica. Sua ação se da de forma direta através do uso de produtos inadequados para a limpeza de moedas.

Os conceitos de metal nobre, corrosão, eletrólito, dentre outros, tão distantes do ofício do professor de História, podem ser trabalhados muito bem nas aulas de química através da proposição de um trabalho em conjunto entre as duas matérias. Em uma realidade onde os alunos frequentam diversas aulas de disciplinas diferentes sobre conteúdos dos mais variados, o uso da interdisciplinaridade é um facilitador do processo de ensino e aprendizagem na medida em que une disciplinas diferentes a partir de um objeto em comum como a moeda, no caso. Isto, sem dúvidas, torna as aulas mais estimulantes ao discente, dando mais sentido a todo conteúdo estudado.

Voltando ao assunto do cuidado com as moedas, a pergunta que surge é como armazená-las e limpá-las para evitar que ocorra a corrosão? Em relação ao armazenamento a primeira opção que surge, sendo também a mais econômica, são 
os envelopes de papel. Além de viável, no próprio envelope podem ser escritos as informações pertinentes à moeda. Porém o problema do papel é que com o tempo ele solta substâncias que podem prejudicar o estado de conservação das moedas. Sendo assim, ao optar pelo uso destes, eles precisam ser trocados constantemente.

Outra opção é o uso de álbum com folhas plásticas com divisórias para a guarda do material. Deve-se ter atenção a qualidade do material plástico, pois a baixa qualidade do plástico pode influenciar na conservação do metal-moeda. Recomenda-se optar por utilizar folhas de acetato, pois estas geralmente não apresentam deformidades com o tempo. Também existe uma embalagem muito comum chamada de holder (ou alvéolo) que são cartões rígidos e vazados protegidos em folhas de acetato. Estes itens podem ser encontrados em casas especializadas de numismática, sendo as folhas e os alvéolos vendidos de forma avulsa ou em conjunto com fichário em capa dura no caso das folhas plásticas.

Existem também possibilidades que vão depender de maiores investimentos. Uma embalagem muito utilizada, principalmente para o transporte das moedas, são embalagens feitas em acrilico transparente. Mais custosos são os chamados medalheiros ingleses, que possuem uma estrutura com diversas gavetas separadas para guardar a moeda isoladamente. Apesar do alto custo, o medalheiro inglês apresenta uma excelente opção para manter a moeda em boas condições para a sua preservação.

Já em relação à limpeza existem visões contraditórias entre limpar ou não a moeda. Muitos numismatas defendem e preferem não limpá-la optando em mantê-la em seu estado natural. Existe um indicador de sua preservação que é a pátina, composto químico que se forma na superfície da peça causado pela exposição a elementos e ao clima, ou seja, é resultado da ação do tempo no metal. Para os dedicados ao estudo da moeda, a pátina pode ser um indicativo da sua autenticidade, bem como pode oferecer informações relevantes quanto a sua datação e origem. A limpeza mal feita, neste caso, pode retirar a pátina da peça mudando suas características naturais.

A opção pela limpeza da moeda deve seguir um rigor técnico com bastante cuidado para evitar danos às peças. Existem também divergências entre especialistas quanto aos procedimentos mais adequados. Aqui, optou-se por descrever a forma mais simples e acessível, sem o uso de produtos químicos e 
com procedimentos pouco invasivos, formulado a partir do guia para limpeza de moedas produzido pela Caravelas Coleções ${ }^{130}$.

De início é preciso ter alguns materiais como: sabão neutro; flanela; papel absorvente; escova de dente; escova de latão; palitos de dente; luvas; e um secador de cabelo. Assim seguem os procedimentos destacados pelo guia:

$1^{0}$ passo: Deixar a moeda em água morna. Isso fará com que o excesso de sujeira fique mais macio, facilitando o processo de limpeza.

$2^{\mathbf{0}}$ passo: Manusear as moedas com cuidado para não danificá-las e segurar apenas pela borda. Fazer a limpeza de forma suave, utilizando a flanela, a escova de dente e de latão e os palitos. Não é necessário aplicar força para limpar sua peça. Utilizar sabão neutro, pois é um produto que não agride sua peça. Outros produtos possuem componentes que não são indicados para moedas.

$3^{0}$ passo: Após concluir a limpeza da peça, lavá-la com bastante água corrente. Não pode haver vestígios de sabão.

$4^{0}$ passo: Pode-se usar o secador de cabelo em temperatura morna, se precisar, para acelerar o processo de secagem. Fazer uso de papel com alta absorção para secar suas moedas completamente. Guardá-la com qualquer vestígio de umidade resultará em oxidação. Deixa a moeda secando por um ou dois dias ao ar livre para secagem total da peça.

$5^{\circ}$ passo: Após a limpeza e a secagem é o momento de guardá-la, utilizando os ensinamentos descritos sobre o acondicionamento de moedas.

\subsection{O uso da tecnologia dos Smart Phones para a identificação de moedas.}

O aparelho de telefone celular é considerado quase sempre um vilão no processo de ensino e aprendizagem nas escolas, pois o seu uso indevido em sala de aula pode retirar a atenção do aluno nas atividades propostas pelo professor, bem como em apreender o conteúdo em aulas expositivas. Sendo assim, a postura da escola e do docente atua sempre no sentido de condenar o uso destes aparelhos

\footnotetext{
${ }^{130}$ Disponível em https://materiais.caravelascolecoes.com.br/como-limpar-moedas Acesso em: 03 de abr. de 2020.
} 
durante as aulas, o que não é um equívoco quando este se torna um entrave. No entanto, acredita-se que o celular, se bem utilizado, pode ser um aliado do professor na tarefa de ensinar História.

Fazer o uso de novas tecnologias tão presentes na realidade dos alunos é uma forma de transformar o ensino tornando a escola um ambiente mais atrativo. Essa é umas das premissas dos autores discutidos anteriormente, bem como é destacado pelos PCNs e a nova BNCC. Embora as reflexões de Mello e Viana estejam mais voltadas a questão do patrimônio, parte-se do principio, neste trabalho, que o aparelho de telefone móvel pode ser considerado um "ponto de contato com o universo cultural do aluno"131, termo destacado pelas autoras. Já os PCNs apontam como objetivos do ensino fundamental que os alunos sejam capazes de "saber utilizar diferentes fontes de informação e recursos tecnológicos para adquirir e construir conhecimentos"132. De igual forma, a nova BNCC indica a importância que:

\begin{abstract}
"a escola compreenda e incorpore mais as novas linguagens e seus modos de funcionamento, desvendando possibilidades de comunicação (e também de manipulação), e que eduque para usos mais democráticos das tecnologias e para uma participação mais consciente na cultura digital. Ao aproveitar o potencial de comunicação do universo digital, a escola pode instituir novos modos de promover a aprendizagem, a interação e o compartilhamento de significados entre professore e estudantes" ${ }^{\prime 133}$.
\end{abstract}

Sendo assim, foram selecionados dois aplicativos de celular que podem auxiliar o aluno no processo de identificação das moedas bem como ajudar na organização e gestão do acervo numismático: o Coinoscope e o Collectgram, ambos disponíveis nos sistemas operacionais Android e IOS. O primeiro é capaz de identificar as moedas do usuário a partir do uso da câmera do celular. O aplicativo faz um escâner da peça identificando-a na sua base dados e fornece diversas informações sobre o item. Já o Collectgram permite consultar informações sobre moedas a partir de um catálogo com mais de 100 mil peças

\footnotetext{
${ }^{131}$ MELLO, Juçara da Silva Barbosa de. VIANA, Ilmara da Silva. Op. Cit. p. 50.

${ }^{132}$ BRASIL. Parâmetros curriculares nacionais: história/Secretaria de Educação Fundamental. Brasília : MEC /SEF, 1998. p. 8.

${ }^{133}$ BRASIL. Ministério da Educação. Secretaria da Educação Básica. Base nacional comum curricular. Brasília, DF, 2016. p. 61.
} 
cadastradas. O diferencial deste app é que nele é possível criar e organizar o acervo do colecionador, facilitando a sua gestão.

\subsection{Como examinar uma moeda.}

Para analisar uma moeda é preciso estabelecer um preciso rigor técnico e metodológico sobre o material utilizado. Entender alguns termos e elementos da numária se faz necessário para que se possa "perguntar" ao documento o que o historiador busca compreender. Acredita-se que este conhecimento técnico pode ser ensinado ao aluno para que o mesmo possa fazer as reflexões que esta pesquisa irá propor. Para isso, o trabalho de Costilhes ${ }^{134}$ que trata exatamente sobre esta questão será utilizado para o apoio técnico e metodológico ajudando na análise das moedas que serão aqui investigadas pelos alunos.

Primeiro é preciso entender a morfologia de uma moeda. Ela é composta do bordo, orla, legenda, campo e exergo, como na imagem abaixo:

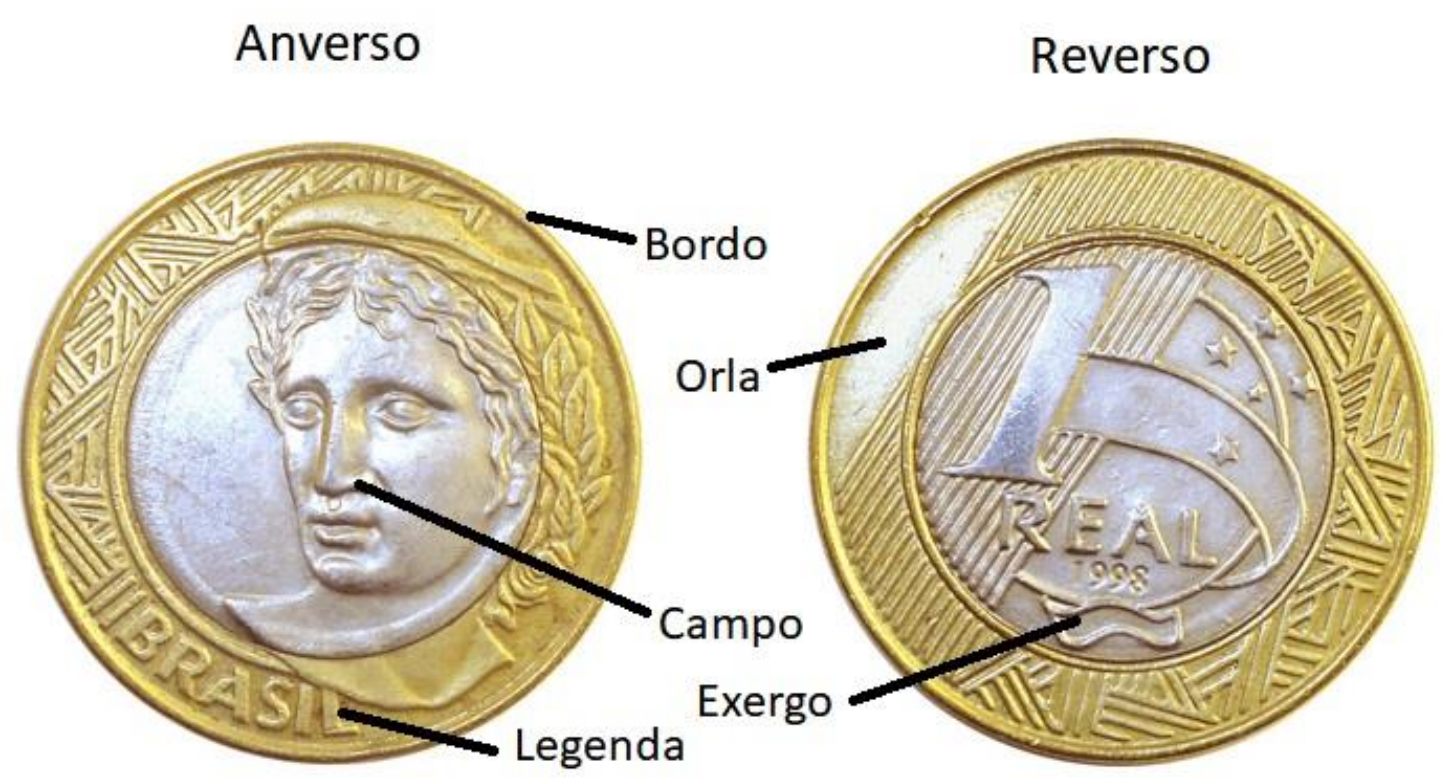

Figura 9 - Morfologia de uma moeda.

Sabe-se que toda moeda possui duas faces, as chamadas cara e coroa. $\mathrm{Na}$ numismática elas possuem um nome técnico. A face onde geralmente encontram-

${ }^{134}$ COSTILHES, Alain Jean. O que é numismática. Editora brasiliense. São Paulo, 1985. p. 35. 
se as efígies e brasões é chamada de anverso. Já a face onde se registra o seu valor é conhecido como reverso.

O bordo é a parte que delimita as duas faces da moeda, na espessura do disco, na qual é impressa a serrilha ou outro desenho. Para facilitar a compreensão dos alunos, pode-se utilizar outros termos ou maneiras para que compreendam termos tão técnicos, como o termo lateral, por exemplo.

Orla é à beira da face da moeda, em geral ligeiramente elevada, para proteger o desenho principal do desgaste, e que é frequentemente desenhada. $\mathrm{O}$ termo orla é de fácil assimilação pelos alunos, palavra muito associada à praia ou ao litoral, na geografia. Pode-se chamá-la de beira, no caso do trabalho com alunos mais novos.

A legenda é a inscrição com o nome do país, do soberano e seus títulos, da cidade, ou ainda frases. Talvez este seja o termo de mais fácil compreensão pelo educando. Legenda está nos filmes, nas fotos, nos documentos apresentados nos livros didáticos, ou seja, o aluno está mais habituado a entender este conceito e identificá-lo no material numismático não é tarefa difícil.

O campo é o espaço central da moeda, no qual aparece o motivo principal ou os símbolos escolhidos pela autoridade emissora. Por ser mais difícil assimilálo, pode-se usar o termo meio ou centro para que os alunos melhor entendam qual parte da moeda a analisar.

Já o exergo é a terminologia mais complicada, pois além do nome pouco conhecido ainda pode ser confundido com a legenda. Esta parte está situada entre o campo e a orla, na parte inferior. É onde se coloca a data da moeda. Para os estudantes, pode-se suprimir a utilização deste termo e apenas pedir a identificação da data de cunhagem. Estas são apenas sugestões de adaptações terminológicas, mas deve-se sempre incentivar o conhecimento de novas terminologias para que os alunos conheçam novas realidades e possibilidades.

Outras observações pertinentes sobre uma moeda que muito podem ajudar a compreendê-la, segundo Costilhes, são: o peso, a forma e o tamanho, o estado de conservação e o metal. Estes fatores podem ser de fácil compreensão pelos alunos, ou não, como no caso do metal utilizado na cunhagem do material, sendo o professor o responsável por orientá-los caso haja dúvidas. 


\subsection{Metodologia das atividades.}

Para as atividades com as moedas, foi definido um recorte temporal que abarca todo o período republicano, como já explicado no primeiro capítulo. Foram elaboradas quatro atividades que abordaram temas presentes no currículo de História de acordo com a nova Base Nacional Comum Curricular (BNCC). Fazem parte deste repertório, portanto: a Proclamação da República; a Era Vargas e a exaltação da figura do Presidente; o Regime Militar e crise econômica, e uma atividade que vai trabalhar com o conceito de sujeito histórico a partir das moedas da Nova República.

A organização das propostas de atividades a seguir se espelharam nas questões discursivas dos exames nacionais de acesso ao PROFHISTÓRIA ${ }^{135}$. Neste exame, é pedido ao candidato que elabore uma proposta de aula em forma de texto, sem a utilização de tópicos ou esquemas, fornecendo as seguintes informações: ano de escolaridade escolhido; título da aula; problematização e objetivos; procedimentos e recursos didáticos a serem utilizados; desenvolvimento dos conceitos e conteúdos a partir da problematização; e atividades de avaliação da aprendizagem. Optou-se por este modelo por acreditar que ele atenda da melhor forma as necessidades impostas pelas reflexões feitas nesta pesquisa, além de seguir a rigor os procedimentos para um plano de aula eficaz.

Estas atividades, além de expostas e analisadas neste capítulo, encontramse no primeiro anexo desta dissertação junto ao guia elaborado, desta vez em forma de tópicos e esquemas. Desta forma, pode-se disponibilizá-las de maneira mais objetiva ao professor que queria aplicar esta metodologia em suas aulas sem a necessidade de ler toda a dissertação.

\footnotetext{
135 As referidas questões discursivas podem sem encontradas em https://www.vestibular.uerj.br/?page id=7763 Acesso em: 11 de abr. de 2020.
} 


\subsubsection{Atividade 1: A numismática e os sujeitos históricos: análise e problematização.}

Esta atividade foi desenvolvida para ser aplicada em todas as séries dos anos finais do ensino fundamental, do $6^{\circ}$ ao $9^{\circ}$ ano, podendo ser aplicada em dois tempos regulares de aula. $\mathrm{O}$ objetivo é trabalhar o conceito de sujeitos históricos e analisar sob uma perspectiva crítica a ideia da construção de uma História oficial, que dá ênfase aos grandes nomes, além de entender que a História é composta por múltiplos sujeitos históricos, inclusive os próprios alunos. $\mathrm{Na}$ nova $\mathrm{BNCC}$, esta atividade enquadra-se na habilidade EF06HI01 ${ }^{136}$ para o $6^{\circ}$ ano, porém sugere-se que ela possa ser estendida para as demais séries dos anos finais do ensino fundamental.

Entendendo que o ensino de História deve seguir a lógica das abordagens historiográficas atuais é feita uma crítica à ênfase dada nos manuais didáticos aos ditos grandes nomes que compõe a História. Ao se trabalhar o conceito de sujeitos históricos a proposta é fazer o aluno compreender que são múltiplos os sujeitos que fazem parte da História (inclusive eles mesmos) e que é preciso trabalhar a partir de outras perspectivas para conhecê-los. Para isso, primeiro eles irão analisar as moedas da última série do Real. Nelas, estão gravados em seu anverso os considerados grandes nomes da História do Brasil como Pedro Álvares Cabral, Tiradentes, D. Pedro I, Marechal Deodoro da Fonseca e o Barão de Rio Branco.

Em seguida, ouvir o samba enredo da escola de samba Mangueira intitulado "História para ninar gente grande" mostrando "a História que a História não conta", cuja letra se encontra disponível junto ao plano de aula da atividade no guia do anexo um. Após isso, trabalhar em uma perspectiva crítica à construção da história do Brasil que dá ênfase aos grandes nomes ${ }^{137}$. Assim, o objetivo é complementar a análise do conceito de sujeitos históricos a partir do uso de fontes diversificadas, no caso a moeda e a música, potencializando a

\footnotetext{
${ }^{136}$ BRASIL. Ministério da Educação. Secretaria da Educação Básica. Base nacional comum curricular. Brasília, DF, 2016. p. 423.

${ }^{137}$ Vale ressaltar que a crítica a esta his toriografia atém-se somente aos livros didáticos que, apesar dos avanços, ainda possui uma abordagem factual com ênfase nas classes dominantes, não considerando, na maioria das vezes, os múltiplos sujeitos que compõem a história.
} 
problematização e o questionamento, como destaca Carvalho e Zampa ${ }^{138}$. Permitindo esta complementariedade e de certa forma um confrontamento, podese perceber equívocos ou então apenas confirmar os mesmos significados encontrados nas outras fontes.

Após isso, estimular a crítica a esta História oficial, que pode ser comprovada ao analisar os personagens cunhados nas moedas de $\mathrm{R} \$ 0,01 \mathrm{R} \$ 0,05$ $\mathrm{R} \$ 0,10 \mathrm{R} \$ 0,25$ e $\mathrm{R} \$ 0,50$ centavos. Destacar uma exceção, que é a atual moeda de $\mathrm{R} \$ 1$. Nela tem-se a efígie de uma mulher, que representa a república, bem como seu anel dourado apresenta motivos marajoaras, etnia indígena do norte do país. A ideia é fazer os alunos entenderem que a História é composta por múltiplos sujeitos históricos, e não apenas os grandes nomes.

Como proposta de avaliação e produção pedir aos alunos para construir, a partir de desenhos em papel, novas moedas para o Brasil, onde sujeitos historicamente negligenciados sejam também contemplados. A análise das moedas segue a linha metodológica proposta pelo Guia de Educação Patrimonial $^{139}$ com o desenvolvimento de quatro etapas para alcançar os objetivos propostos:

\footnotetext{
${ }^{138}$ CARVALHO, M. P. de. e ZAMPA, V. C. da S. Op. Cit. p.

${ }^{139}$ HORTA, Maria de Lourdes Pereira. GRUNBERG, Evelina. MONTEIRO, Adriane Queiroz. Guia Básico de Educação Patrimonial. Instituto do Patrimônio Histórico e Artístico Nacional, museu Imperial, 1999.
} 


\begin{tabular}{|c|c|c|}
\hline Etapas & Recursos/ Atividades & Objetivos \\
\hline 1) Observação & $\begin{array}{l}\text { exercícios de percepção } \\
\text { visual/sensorial, por meio de } \\
\text { perguntas, manipulação, } \\
\text { experimentação, medição, } \\
\text { anotações, comparaçăo, } \\
\text { dedução, jogos de detetive ... }\end{array}$ & $\begin{array}{l}\text { - identificação do objeto/ } \\
\text { função/significado; } \\
\text { - desenvolvimento da } \\
\text { percepção visual e } \\
\text { simbólica. }\end{array}$ \\
\hline 2) Registro & $\begin{array}{l}\text { desenhos, descrição verbal ou } \\
\text { escrita, gráficos, fotografias, } \\
\text { maquetes, mapas e plantas } \\
\text { baixas ... }\end{array}$ & $\begin{array}{l}\text { - fixação do conhecimento } \\
\text { percebido, } \\
\text { aprofundamento da } \\
\text { observação e análise } \\
\text { crítica; } \\
\text { - desenvolvimento da } \\
\text { memória, pensamento } \\
\text { lógico, intuitivo e } \\
\text { operacional. }\end{array}$ \\
\hline 3) Exploração & $\begin{array}{l}\text { Análise do problema, } \\
\text { levantamento de hipóteses, } \\
\text { discussão, questionamento, } \\
\text { avaliação, pesquisa em outras } \\
\text { fontes como bibliotecas, } \\
\text { arquivos, cartórios, } \\
\text { instituições, jornais, } \\
\text { entrevistas. }\end{array}$ & $\begin{array}{l}\text { desenvolvimento das } \\
\text { capacidades de análise e } \\
\text { julgamento crítico, } \\
\text { interpretação das } \\
\text { evidências e significados. }\end{array}$ \\
\hline 4) Apropriação & $\begin{array}{l}\text { recriação, releitura, } \\
\text { dramatização, interpretação } \\
\text { em diferentes meios de } \\
\text { expressão como pintura, } \\
\text { escultura, drama, dança, } \\
\text { música, poesia, texto, filme, } \\
\text { vídeo. }\end{array}$ & $\begin{array}{l}\text { envolvimento afetivo, } \\
\text { internalização, } \\
\text { desenvolvimento da } \\
\text { capacidade de auto- } \\
\text { expressão, apropriação, } \\
\text { participação criativa, } \\
\text { valorizção do bem cultural. }\end{array}$ \\
\hline
\end{tabular}

$\mathrm{Na}$ observação os alunos fazem o manuseio das fontes a partir de outro olhar. Se antes eles viam as moedas apenas como um meio de pagamento, agora a proposta é que eles a vejam como uma fonte de conhecimento e estudo da História. É importante nesta fase que eles a observem desenvolvendo uma percepção visual e simbólica do objeto com o apoio de questões levantadas pelo professor.

Seguindo com o registro das fontes, os alunos fazem a descrição do objeto. Aspectos como o tamanho, o ano de cunhagem, as efígies, matéria prima, os símbolos e outros aspectos serão levantados e sistematizados em uma tabela, como nas fotografias que seguem abaixo. Esta etapa visa à fixação do conhecimento percebido bem como o aprofundamento da observação e da análise crítica. 

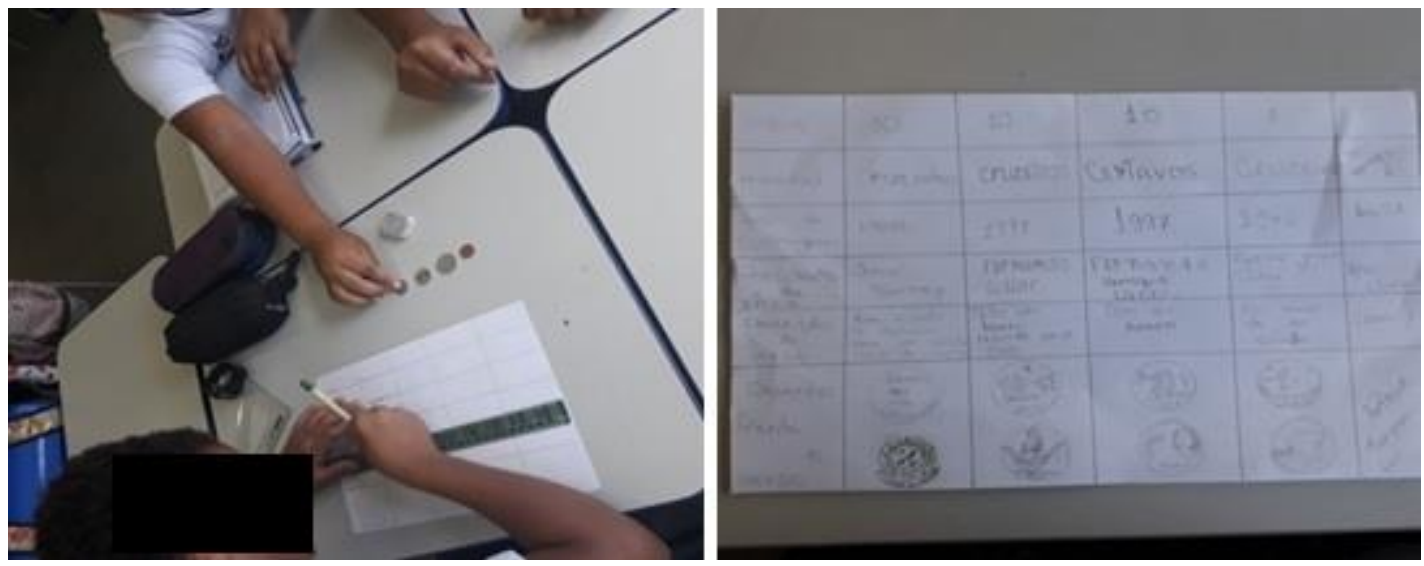

Figura 10 - Atividade de registro de fontes numismáticas. Acervo pessoal.

A exploração é a hora de levantar hipóteses, discutir e questionar. Ao identificar os personagens históricos cunhados nas moedas na etapa anterior, a exploração permitirá que os alunos desenvolvam sua capacidade crítica, fazendoos perceber que estes personagens reproduzem a ideia de uma identidade nacional oficial e como isso precisa ser questionado. Com o apoio de outra fonte, o samba enredo da mangueira de 2019, com o intuito de entender como a História é composta por múltiplos sujeitos históricos, e não apenas os ditos oficiais.

A etapa da apropriação também pode ser considerada uma atividade final avaliativa, onde os alunos fazem produção do resultado das interpretações. A apropriação permite que eles façam recriações e releituras. Sendo assim, foi proposto que eles recriassem novas moedas para o Brasil, só que desta vez contemplando efígies de sujeitos historicamente negligenciados pelos estudos históricos ou até mesmo retratando a si mesmos, amigos, ou familiares permitindo que eles se vejam como sujeitos que compõem a História. Como proposto no guia, pretende-se com isso desenvolver a capacidade de auto expressão, apropriação, participação criativa e valorização do bem cultural.

\subsubsection{Atividade 2: As moedas do Brasil e a Transição da Monarquia para a República.}

Esta atividade pode ser aplicada em turmas de $8^{\circ}$ ano no final do ano letivo ou então no $9^{\circ}$ ano no início do primeiro bimestre perfazendo um total de dois tempos de aula. O objetivo é provocar nos alunos uma reflexão acerca da transição política do regime monárquico brasileiro para o regime republicano. Em 
alinhamento com a nova base curricular de História, a atividade corresponde à habilidade EF09HI01 ${ }^{140}$ da BNCC que propõe descrever e contextualizar os principais aspectos sociais, culturais, econômicos e políticos da emergência da República no Brasil.

A proposta é fazer os alunos desenvolverem a capacidade analítica a partir da observação das mudanças ocorridas nas simbologias cunhadas nas moedas do período anterior e posterior à proclamação da República. Além da parte analítica, a tarefa objetiva desenvolver nos alunos a consciência da preservação e organização das fontes históricas estudadas. Assim, foi proposto o desenvolvimento das técnicas de limpeza das peças, classificação e guarda do material, conforme descrito neste capítulo.

O professor deverá utilizar como fontes moedas do Segundo Reinado e da Primeira República, que trazem em seus anversos e reversos, respectivamente, os símbolos monárquicos e republicanos. Outros materiais necessários para a atividade é o celular smartphone com o aplicativo Collectgram (para a gestão e organização do acervo) e folhas A4 para a confecção de envelopes de papel utilizados para a guarda do material.

A proposta pode ser aplicada em dois momentos. Nas turmas de $8^{\circ}$ ano sempre no final da aula sobre a crise do Império, e no $9^{\circ}$ ano sempre no início da aula sobre a Proclamação da República. Inicialmente, se faz necessário uma explanação sobre alguns símbolos monárquicos e republicanos. São eles: o Brasão do Império, a imagem do Imperador Pedro II, a Brasão de armas da República, o Cruzeiro do Sul, e a mulher com barrete frígio, símbolo republicano.

\footnotetext{
${ }^{140} \mathrm{http} / / / \mathrm{basenacionalcomum.mec.gov.br/abase/ \# fundamenta//historia-no-ensino-fundamental-}$ anos-finais-unidades-tematicas-objetos-de-conhecimento-e-habilidades Acesso em: $27 \mathrm{de} \mathrm{dez}$. de 2019.
} 

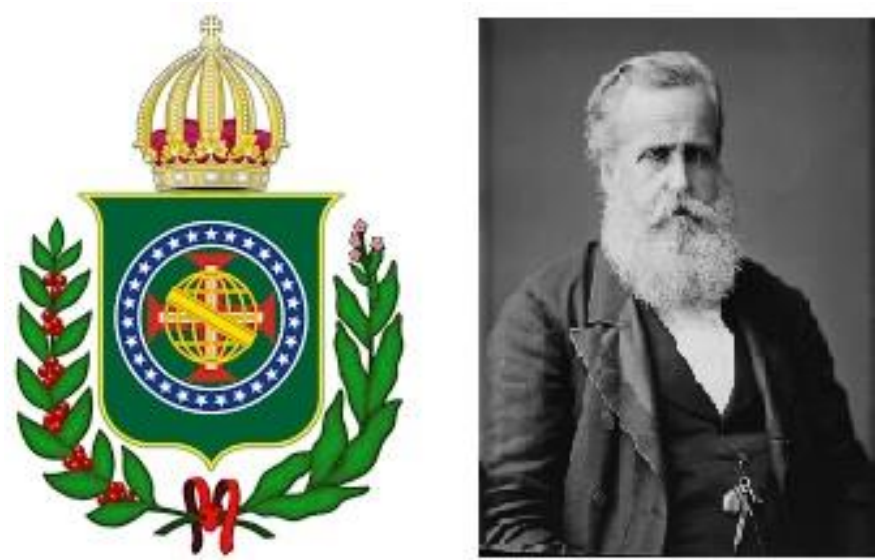

Figura 11 - Imagens da monarquia: À esquerda o Brasão Imperial, com ramos vegetais de café e tabaco, a esfera armilar com a Cruz de Cristo no centro circulado pela faixa azul com estrelas que representando as províncias do Império, e a coroa imperial no topo. À direita, fotografia do Imperador Pedro II em sua fase idosa.
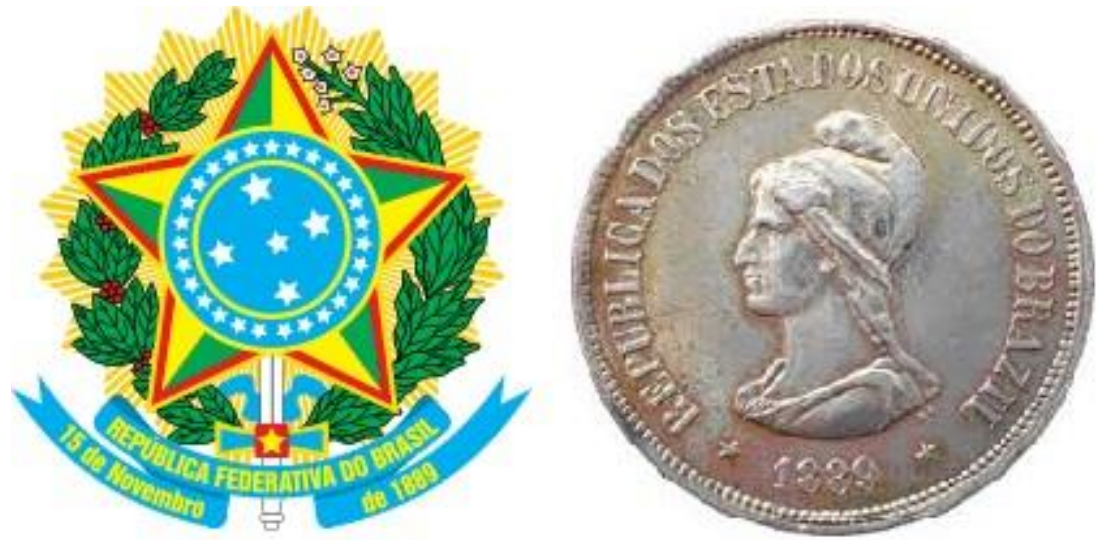

Figura 12 - Símbolos republicanos. À esquerda, Brasão das Armas da República, com ramos vegetais de café e tabaco, escudo azul celeste no centro como Cruzeiro do Sul circulado pela faixa azul com estrelas que representam os Estados, pousado em uma grande estrela. Espada em pala, e abaixo legenda República Federativa do Brasil com a data da Proclamação da República. À direita, figura da mulher que representa a República em moeda de 1889.

A forma como os alunos tomam conhecimento sobre estas simbologias pode estar inserida no próprio curso das aulas regulares. Explanações, por exemplo, sobre o Brasil Império devem ter como recurso elementos iconográficos onde estão incluídos o Brasão e as diversas representações da imagem do Imperador. Ou então, no caso da mulher republicana, pressupõe-se que os alunos já conheçam esta representação inspirada na Marianne francesa, presente no quadro A liberdade Guiando o Povo de Eugène Delacroix muito difundida nas aulas sobre os movimentos revolucionários franceses do século XIX. Porém, estas imagens podem ser revistas antes da realização da atividade como forma de revisão, focando nos detalhes que cada símbolo apresenta. 
Após isso, a turma pode ser dividida em grupos e cada grupo receberá determinada quantidade de moedas do Império e da República. Seguindo a proposta de Horta et $a^{141} l$ descrita na atividade 1, os alunos irão fazer o processo de observação, registro e exploração das fontes através de um roteiro estabelecido pelo professor. Primeiro, eles devem colocar as moedas lado a lado em ordem cronológica, observando a sua data de cunhagem. Em seguida, devem detalhar toda a simbologia das fontes com calma, identificando-as e descrevendo-as. Enfim, o professor deverá solicitar que eles observem a mudança de padrão dos símbolos antes e depois do ano de 1889, e pedir para que formulem hipóteses explicando a razão desta mudança. Assim, a partir da inferência, objetivou-se fazer com que os alunos reconhecessem que as mudanças das efígies e da heráldica nas moedas representam um momento maior na História política do país simbolizado pela Proclamação da República.

Como atividade extra, os alunos podem fazer a organização do acervo estudado, montando uma coleção. Primeiro, confeccionando pequenos envelopes de papel a partir de uma folha tamanho A4, para a guarda das moedas. Em seguida, anotar nos envelopes as informações sobre as moedas, enumerando cada envelope com seu "número de tombo"142, sendo esse número listado em um caderno para o controle do acervo. Também pode-se fazer o uso do aplicativo Collectgram onde todas as moedas utilizadas podem ser cadastradas facilitando a gestão do acervo utilizado.

O processo de avaliação da aprendizagem pode se ater a diversos fatores, como a capacidade do discente em fazer as conexões entre a análise do material e o conteúdo estudado, bem como a atuação em conjunto do grupo e a disciplina em todas as etapas do trabalho. Esta parte avaliativa deve considerar a heterogeneidade do educando levando em consideração que nem todos vão alcançar os objetivos propostos da mesma forma. Convém-se destacar a dedicação do mesmo na realização das tarefas.

141 HORTA, Maria de Lourdes Pereira. GRUNBERG, Evelina. MONTEIRO, Adriane Queiroz. Guia Básico de Educação Patrimonial. Instituto do Patrimônio Histórico e Artístico Nacional, museu Imperial, 1999.

142 O número de tombo é o número sequencial atribuído a uma peça quando ela é cadastrada em um sistema para gestão de acervo. O número de tombo tem como função tornar o exemplar único, diferenciando-o de outros, além de contribuir para o controle de itens do acervo. 


\subsubsection{Atividade 3: Estado Novo: a numismática e o culto a imagem do Presidente Vargas.}

Esta atividade deve ser realizada em turmas de $9^{\circ}$ ano do ensino fundamental. $\mathrm{Na}$ nova Base Nacional Comum Curricular ela se enquadra no "Período varguista e suas contradições"143 relacionada a habilidade EF09HI06, sendo o objetivo o de compreender a estratégia varguista no culto a imagem do presidente durante o Estado Novo. A proposta deste trabalho é que ele seja dinâmico e que seu tempo de duração não seja maior do que vinte minutos, sempre no início dos estudos sobre a Era Vargas. Para que ele seja feito de forma rápida, a sugestão é que o professor proponha a divisão da turma em duplas ou individualmente, evitando assim maior dispêndio de tempo para a organização dos alunos.

A ideia de se fazer a análise das moedas no início da aula vai ao encontro de algumas premissas abordadas na fundamentação teórica desta pesquisa. Primeiro, é importante que o uso das fontes não seja apenas feita com um caráter ilustrativo do que foi dito pelo professor, como destacaram os diversos autores abordados. Assim, utilizando-a como introdução de um conteúdo anula-se seu caráter confirmatório. Essa é a visão defendida por Bittencourt ${ }^{144}$, por exemplo, ao defender o uso delas para introduzir um tema de estudo.

Os materiais necessários para a elaboração deste trabalho são as moedas do período republicano e uma lista a ser entregue aos alunos constando todos os presidentes da época. Sugere-se que cada aluno ou dupla receba em torno de dez a quinze moedas para a análise, sendo uma obrigatoriamente cunhada entre os anos de 1938 e 1945, onde figura a efígie do presidente Getúlio Vargas. É importante também que o conjunto de peças utilizadas abarque todas as fases da História republicana o que possibilita a compreensão da amplitude deste momento.

\footnotetext{
${ }^{143}$ BRASIL. Ministério da Educação. Secretaria da Educação Básica. Base nacional comum curricular. Brasília, DF, 2016. p. 428.

144 BITTENCOURT, Circe Maria Fernandes. Ensino de história: fundamentos e métodos. $2^{\mathrm{a}}$ edição. Editora Cortez. São Paulo, 2008.
} 
Assim, se apoiando na lista com os nomes de todo os presidentes da república e observando atentamente as datas de cunhagem das moedas bem como os símbolos e efígies gravados nos anversos de cada moeda recebida, os alunos deverão identificar o único presidente da República que durante seu governo emitiu moedas com a sua própria efígie. Com isso, o professor irá propor aos alunos que formulem hipóteses para a ocorrência de moedas com a efígie do presidente Vargas durante seu próprio governo, podendo ser feita de forma oral estimulando a participação de todos, ou escrito no caderno. Após esta análise documental e problematização, dar-se-á inicio a aula expositiva sobre a Era Vargas.

Como é uma atividade rápida, a avaliação da aprendizagem desta proposta pode se dar a partir do comprometimento do aluno e das hipóteses formuladas por eles. Porém a preocupação em se avaliar, neste caso, não deve se sobrepor ao alcance do objetivo geral. Isso implica em entender que independe se o aluno alcançou ou não a elaboração de uma hipótese bem fundamentada, a ideia é possibilitar uma reflexão inicial sobre um momento único da história da República do Brasil.

\subsubsection{Atividade 4: Ditadura militar, crise econômica e a numismática.}

Atividade desenvolvida para as turmas de $9^{\circ}$ ano do ensino fundamental com previsão de duração de um tempo de aula, em torno de quarenta e cinco a cinquenta minutos. Dentro da nova BNCC, o trabalho se insere no objeto de conhecimento "ditadura civil-militar e os processos de Resistência""145, com maior destaque aos aspectos econômicos da época, sendo relacionado à habilidade EF09HI20 da base. Com uma proposta interdisciplinar amparada na matemática, também foi estimulado a elaboração e resolução de problemas que envolvam porcentagens, relacionado à habilidade EF09MA05 da nova $\mathrm{BNCC}^{146}$.

Nesta tarefa, a turma deverá separar-se em equipes, e a eles serão apresentadas as fontes numismáticas, constando moedas de Cruzeiro dos anos de 1964 até 1985 , período que perdurou a ditadura militar. O trabalho com este tipo de fonte apresenta uma oportunidade metodológica diversificada. Ela faz o aluno,

\footnotetext{
${ }^{145}$ BRASIL. Op. Cit. p. 430.

${ }^{146}$ BRASIL. Op. Cit. p. 316.
} 
a partir da análise dos dados, perceber as mudanças econômicas do período através de algo muito presente no cotidiano das pessoas: o dinheiro. Esta proposta se ampara em toda a discussão teórica do capítulo inicial, onde autores destacam a necessidade da apropriação dos elementos vividos pelos alunos como estratégia para a compreensão dos temas históricos. Assim, inicialmente os grupos vão receber as moedas e observá-las. Em seguida, eles ordenarão as moedas em segmentos respeitando uma sequência cronológica da época, conforme tabela e instruções que será entregue e estão anexadas dentro do guia nesta pesquisa (anexo 1, página 130).

Estes segmentos ordenados estão relacionados a diferentes contextos econômicos da ditadura, são eles: 1964 - 1967 (PAEG); 1968 -1973 (milagre econômico); 1974 - 1979 (marcha forçada); 1980 - 1983 (crise da dívida) e 1984 - 1985 (crise da dívida). A partir desta classificação o objetivo desta atividade é fazer o aluno perceber a ocorrência de processos inflacionários associados aos diferentes contextos econômicos descritos.

Isso será possível a partir do uso de um recurso interdisciplinar matemático que é a porcentagem. Os alunos farão o cálculo percentual das alterações do maior valor das moedas de um período ao outro. Era muito constante à época, o governo militar no uso de decretos-leis, extinguir a fração do Cruzeiro denominada centavo, ou então corrigir os valores do dinheiro aumentando-os acompanhando os processos de inflação. A criação do Cruzeiro Novo em $1967^{147}$ alterou o padrão monetário, e a conversão da moeda antiga para a nova foi de 1000/1. Ou seja, cada mil cruzeiros equivaleria a um Cruzeiro Novo. Neste sentido, os alunos deverão se ater as moedas de Cruzeiro cunhadas até 1967, dividindo-as por mil para se chegar ao valor equiparado ao padrão monetário seguinte.

Com isso, através da percepção dos constantes alterações dos valores monetários verificados nas fontes é que será possível fazer o educando inferir sobre as transformações econômicas do período, como um indicativo de crise na economia brasileira. Todas estas informações apuradas pelos alunos através das fontes numismáticas poderão ser confrontadas com outras fontes pesquisadas,

147 Decreto $\mathrm{n}^{\mathrm{o}}$ 60.190, de 8 de fevereiro de 1967 instituiu o Cruzeiro Novo. Em https://www2.camara.leg.br/legin/fed/decret/1960-1969/decreto-60190-8-fevereiro-1967-401727publicacaooriginal-1-pe.html Acesso em 21 de abr. de 2020. 
sejam elas orais, escritas, dentre outras, que mostrem a realidade econômica da época a fim de confirmar ou não o conteúdo apreendido na aula.

O processo de avaliação da aprendizagem pode considerar elementos como a atuação do educando no trabalho em grupo, o comprometimento e a sua disciplina. O principal aspecto a ser avaliado é o preenchimento da tabela a partir da análise das fontes, porém é preciso entender heterogeneidade do aluno considerando que nem todos vão alcançar os objetivos propostos da mesma forma. 


\section{Desenvolvimento das atividades e análise dos resultados.}

\subsection{Atividade 1.}

Turma: 801 (2019)

A atividade foi aplicada no último bimestre de 2019 em uma turma de $8^{\circ}$ ano. Essa turma é acompanhada pelo professor desde o $6^{\circ}$ ano, portanto existe certa afinidade entre alunos e docente, bem como eles já estão acostumados com as metodologias de ensino aplicadas e a forma como o conteúdo é trabalhado. Os dois tempos definidos no planejamento da tarefa foram ideais para a realização da mesma, visto que foi possível fazer a chamada, organizar a turma em grupos, aplicar a atividade, e arrumar a sala de aula posteriormente dentro de 1 h30 de aula.

$\mathrm{Na}$ aula anterior foi pedido para que os alunos levassem as moedas da $2^{\mathrm{a}}$ familia do Real e foi explicado que uma atividade especial seria realizada com elas. Há de se destacar que o pedido foi feito em uma segunda-feira e a aula seria realizada no dia seguinte. Acreditou-se que datas próximas não acarretaria no esquecimento da tarefa. No entanto, no dia da aula apenas cinco dos trinta e dois alunos presentes levaram-nas, sendo que apenas um aluno conseguiu levar toda a segunda série completa do real requerida.

Isto gerou certo estranhamento e desconforto visto que esta turma, no geral, sempre foi muito engajada nas atividades propostas, inclusive em trabalhos já desenvolvidos com foco na numismática quando ainda eram alunos do sexto ano. Sendo assim, foi preciso analisar as razões que levaram ao desinteresse maciço dos alunos buscando entender alguns problemas para corrigi-los em atividades futuras.

Primeiramente, percebe-se um desgaste da turma na etapa final do ano letivo, visto que a atividade foi executada no início do quarto bimestre de 2019. Outra razão era que a turma encontrava-se envolvida na realização de projetos para a feira do conhecimento que aconteceria no sábado seguinte, sendo esta a razão alegada por muitos. Outros alegaram que não possuíam nenhuma destas moedas em casa, mas esta questão não será julgada aqui. Por fim, os que levaram apenas parte da série de moedas alegaram que não as possuía por completo, principalmente a de um centavo, o que é compreensível visto que esta já se 
encontra fora de circulação. $O$ único aluno que a levou é um entusiasta do colecionismo e já possuía algumas destas em sua coleção.

A ideia de solicitar aos alunos que levassem suas próprias moedas visou um estímulo a mais a pesquisa e as novas descobertas. Acreditou-se que isso não seria um entrave, pois as moedas solicitadas estão em circulação atualmente. Esta hipótese foi abortada neste trabalho quando realizado no final do ano letivo, deixando este momento para períodos iniciais do ano. Sendo assim, visando evitar problemas desta natureza, nas atividades seguintes o professor é o encarregado de levar todas as fontes para a análise dos alunos.

O desenvolvimento da atividade ocorreu dentro do planejado. Foram formados seis grupos de quatro a seis alunos por grupo, sendo que apenas dois destes seis grupos estavam compostos por alunos que levaram as moedas para a análise. Foi feita uma explanação inicial sobre o conceito de sujeitos históricos, observando exemplos práticos em que o livro didático dava destaque aos nomes da chamada História oficial. Como eles estavam estudando o período Joanino e o processo de independência do Brasil, foi fácil identificarem o realce a nomes como Napoleão Bonaparte, D. João, e o então príncipe regente Pedro.

Foi pedido que os alunos fizessem uma apuração sobre as informações contidas nas moedas, e que tivessem maior atenção às efígies dos personagens históricos nos anversos. Infelizmente, os grupos que não levaram as moedas não se entusiasmaram em fazer esta parte, mesmo tendo sido incentivados para que a fizessem observando junto aos grupos que tinham o material completo. Já os grupos envolvidos no trabalho conseguiram identificar todos os personagens indicados, e com o auxilio do professor foi explicado um pouco sobre a biografia de algum deles, como o caso do Barão do Rio Branco, desconhecido por todos.

Em seguida foi trabalhado o samba da Mangueira ${ }^{148}$, primeiramente fazendo uma leitura do texto em conjunto com a turma sem o áudio, e foi explicando um pouco da história do samba e seu conteúdo, citando todos os nomes expostos na letra. A música foi tocada em seguida e a turma muito se animou, contrariando uma ideia inicial de que eles não apreciariam devido ao ritmo não ser o preferido da classe. Com a análise feita das moedas, o sambaenredo, e com a explanação sobre o conceito de sujeitos históricos foi estimulada

\footnotetext{
${ }^{148}$ Samba enredo da G.R.E.S. Estação Primeira de Mangueira de 2019, intitulado "História pra ninar gente grande". Letra disponível no anexo 1, página 125.
} 
a capacidade de crítica do aluno, pedindo para que eles formulassem hipóteses para a escolha dos personagens gravados nas moedas da $2^{\mathrm{a}}$ familia do Real. Como resposta, foi constatado que eles conseguiram perceber que estes personagens reproduzem a ideia de uma identidade nacional oficial e como isso precisa ser questionado.

Como resultado final proposta foi a elaboração de novas moedas para o Brasil, considerando nas efígies os sujeitos historicamente negligenciados. Para tanto, foram entregue aos alunos cartolinas, tesoura, cola, compasso, canetinhas e lápis de colorir para que elaborassem a nova família do Real. Dos seis grupos apenas quatro entregaram algum resultado, e destes quatro grupos, apenas dois apresentaram resultado relacionado à proposta da atividade. Dos dois grupos que fizeram, mas não apresentaram o resultado dentro da proposta, um gravou apenas bandeiras do Brasil nos anversos das moedas, e o outro deixou o anverso em branco, elaborando apenas o reverso com os valores.

Dos dois grupos que fizeram a atividade dentro da proposta, foram feitas homenagens ao jogador Zico com a camisa da seleção brasileira de futebol; ao piloto Ayrton Senna, às florestas do Brasil com uma mensagem escrita "nem tudo é desastre ambiental"; à abolição da escravidão com um desenho e a mensagem "a escravidão não acabou"; e por fim uma homenagem a Marielle Franco. O outro grupo fez uma consideração aos alunos; ao soldado; aos escravos; aos indígenas; e ao professor.

Importa destacar que os únicos dois grupos que seguiram todas as etapas pedidas pelo professor foram exatamente os únicos que apresentaram resultado dentro da proposta da atividade. Nas próximas atividades desenvolvidas, foi importante fazer um esforço para que todos os alunos fossem incluídos em todos os processos do trabalho, embora com a amostragem apurada seja possível verificar pontos positivos que confirmem a hipótese desta pesquisa. 


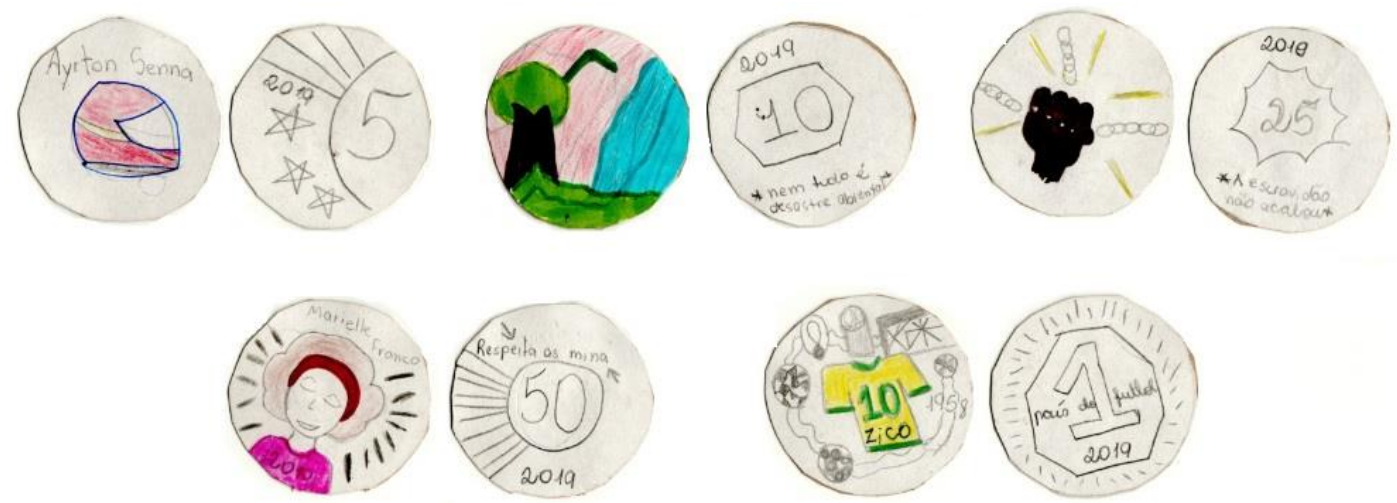

Figura 13 - Moedas produzidas pelo grupo. Em ordem da esquerda para a direita: piloto Ayrton Senna, natureza, abolição, vereadora Marielle, e jogador Zico.
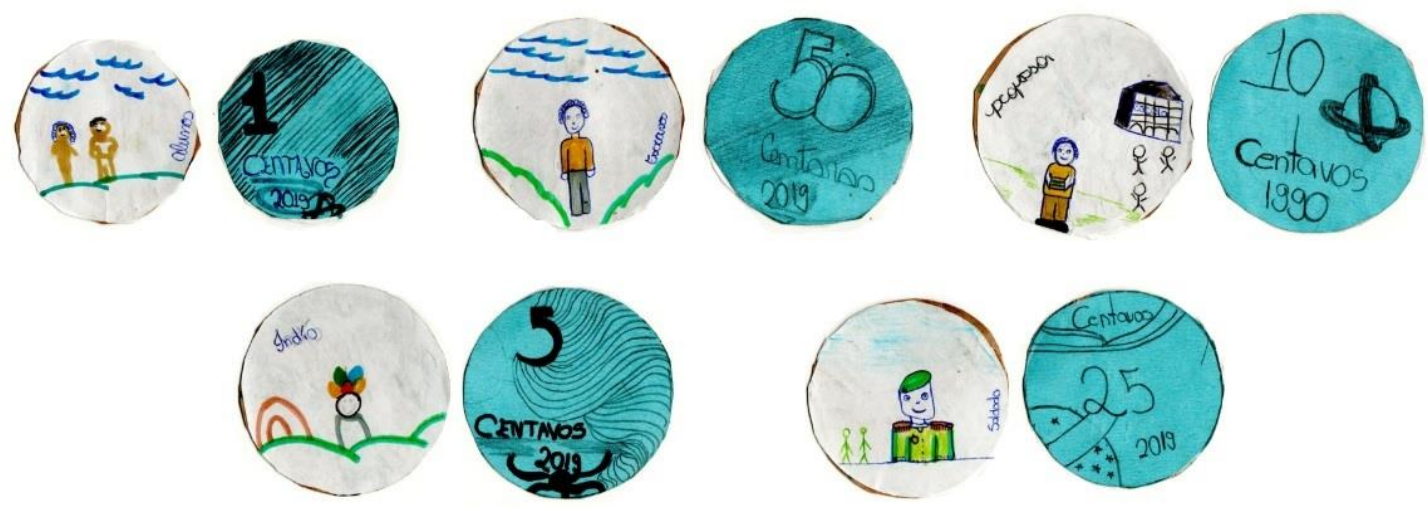

Figura 14 - Moedas produzidas pelo segundo grupo. Em ordem da esquerda para a direita: os alunos, os escravizados, o professor, os indígenas, e o soldado.

\section{Turma: 601 e 603 (2020)}

No início do ano letivo de 2020 a atividade foi aplicada novamente. Desta vez em duas turmas de $6^{\circ}$ ano, se enquadrando dentro do conteúdo previsto para o primeiro bimestre que versa sobre a introdução aos estudos históricos. Como as turmas apresentam características semelhantes, seja na composição etária, série, tamanho e comprometimento do alunado, a análise dos resultados foi feita em conjunto.

A partir das experiências positivas e negativas observadas na aplicação da mesma atividade no final de 2019, novas direções foram adotadas. Primeiro, coube ao professor o dever de levar as fontes que seriam utilizadas no trabalho. Desta forma, todos os grupos formados foram contemplados com o conjunto de moedas da $2^{\mathrm{a}}$ familia do Real para a análise, o que incluiu toda a turma no processo. Com isso, verificou-se, nas duas turmas, certa empolgação para a 
realização da tarefa, bem como maior foco na atenção aos passos explicados pelo professor.

Porém, há de se considerar que, nesta unidade escolar, as turmas de $6^{\circ}$ ano com crianças na faixa dos onze anos apresentam, no geral, uma característica de serem mais atenciosas e calmas, o que vai mudando com o passar das séries. Sendo assim, torna-se impreciso afirmar que o fato de todos os alunos estarem com o material completo resultou em maior foco para a realização da atividade. Por outro lado, notou-se que a inclusão de todos os alunos em todas as etapas da atividade culminou, em termos quantitativos, em melhores resultados na produtividade. Outro fator considerado para entender o maior envolvimento dos alunos é que a atividade foi aplicada no inicio do ano letivo e os alunos apresentavam maior disposição para desenvolver o trabalho.

Todas as etapas foram concluídas dentro do período planejado de dois tempos de aula, sendo cada tempo de quarenta e cinco minutos. O período predeterminado foi o suficiente para fazer a chamada no início da aula, explicar a atividade, organizar a turma em grupos, aplicar e resolver o trabalho, bem como arrumar a sala de aula nos minutos finais.

As turmas se dividiram em grupos entre quatro a seis alunos por grupo, com a escolha dos componentes feita a critério deles, sendo o limite mínimo e máximo de alunos por grupo estabelecido pelo professor. A experiência mostrou melhores resultados e maior participação discente nos grupos com quatro alunos. Sendo assim, nas atividades seguintes o número máximo de quatro alunos foi um critério rígido estabelecido para a organização da atividade.

Constatou-se que em turmas de $6^{\circ}$ ano existe uma memória recente a respeito de personagens históricos ditos oficiais, como o Marechal Deodoro da Fonseca, por exemplo. Acredita-se que isso se deve ao fato de o ensino de História nos anos iniciais do ensino fundamental $\left(1^{\circ}\right.$ ao $5^{\circ}$ ano $)$ ser muito voltado a valorizar as datas históricas e os principais personagens destes acontecimentos. Outro personagem reproduzido por eles na produção das novas moedas foi Zumbi dos Palmares, líder muito estudado pelos alunos nos anos iniciais em referência ao Dia da Consciência Negra.

O momento de explicar os passos da atividade para os alunos, quanto à narrativa adotada pelo professor, foi diferente no $6^{\circ}$ ano. Com alunos na faixa dos onze anos, recém-ingressados nos anos finais do ensino fundamental, a forma de 
falar do professor deve ser mais clara e lúdica. A explanação sobre os sujeitos históricos com eles foi positiva. Foi possível provocar uma reflexão sobre como este conceito vem sendo utilizado no ensino de História justamente por ele virem com uma bagagem dos anos iniciais. Além do já mencionado primeiro Presidente da República, muitos alunos lembraram da imagem da Princesa Isabel, chamada por eles de "libertadora dos escravos", e de Pedro Álvares Cabral, lembrado como o "cara que descobriu o Brasil".

A tarefa de examinar as moedas e descobrir as efígies nelas gravadas não foi um obstáculo, porém foi necessário o apoio constante do professor supervisionando os grupos a fim de sanar eventuais dúvidas, diferente do $8^{\circ}$ ano que realizou esta parte com mais autonomia. Posteriormente, foi apresentado o samba da mangueira, fazendo uma leitura da letra com a turma, junto a uma breve explanação sobre o tema, e seguindo à apresentação do áudio. As turmas gostaram muito desta canção da mesma forma que o $8^{\circ}$ ano. Mesmo o carnaval das Escolas de Samba cariocas não sendo algo muito próximo à realidade destes alunos do interior, a melodia da canção contribuiu muito para uma aproximação positiva.

Como atividade final, os alunos construíram as novas moedas para o Brasil considerando nas efígies o conceito de sujeitos históricos na sua amplitude. Eles receberam todo o material para a atividade, como tesoura, cola, canetinhas e lápis de colorir, além de cartolinas para a criação das moedas. Este material foi todo fornecido pela escola, por esta razão não foi pedido para que eles os trouxessem de casa.

Todos os grupos apresentaram resultados, porém alguns fugiram da proposta esperada que era a de valorizar sujeitos históricos não considerados na dita História oficial. Ao buscar as razões para a fuga da proposta inicial, algumas questões foram pensadas. Primeiramente, um fato positivo é que a atividade foi toda explicada antes da turma se organizar em grupos, proporcionando melhor entendimento dos alunos. Os grupos que fugiram da proposta foram formados por seis integrantes, o que gerou maior conversa paralela entre os alunos, e pode ter atrapalhado no resultado. Por fim, é preciso considerar que nem todos os alunos vão alcançar os mesmos resultados, pois existem especificidades entre cada estudante, e cabe ao professor melhor atender os alunos que apresentam maiores dificuldades, o que pode ter faltado naquele momento. Infelizmente, em turmas 
com mais de trinta alunos, mesmo que dividida em grupos, uma atenção pormenorizada do professor por muito tempo pode não ser efetiva.

Das moedas produzidas, cinco grupos privilegiaram os próprios alunos nas respectivas efígies gravadas, além do professor, destacado por um grupo. Outras homenagens a se destacar foi a figura de Zumbi do Palmares, escolhida por dois grupos, a de Jesus Cristo e de um indígena Tupi, por um grupo. Os grupos que fugiram da proposta reproduziram as moedas da $2^{\mathrm{a}}$ familia do real a sua semelhança, como uma cópia. Outro grupo destacou a imagem de pássaros, e outro reproduziu apenas o reverso da moeda, com o seu valor de face.

A análise dos resultados na produção das novas moedas permite inferir a viabilidade desta atividade em fazer os alunos refletirem sobre a amplitude da noção dos sujeitos históricos. Pode-se observar que eles foram capazes de notar que os personagens gravados nas moedas da $2^{\mathrm{a}}$ familia do Real reproduzem a ideia de uma identidade nacional oficial, e o trabalho que fizeram foi no sentido de questionar esta visão. Abaixo, alguns dos resultados elaborados pelos alunos:
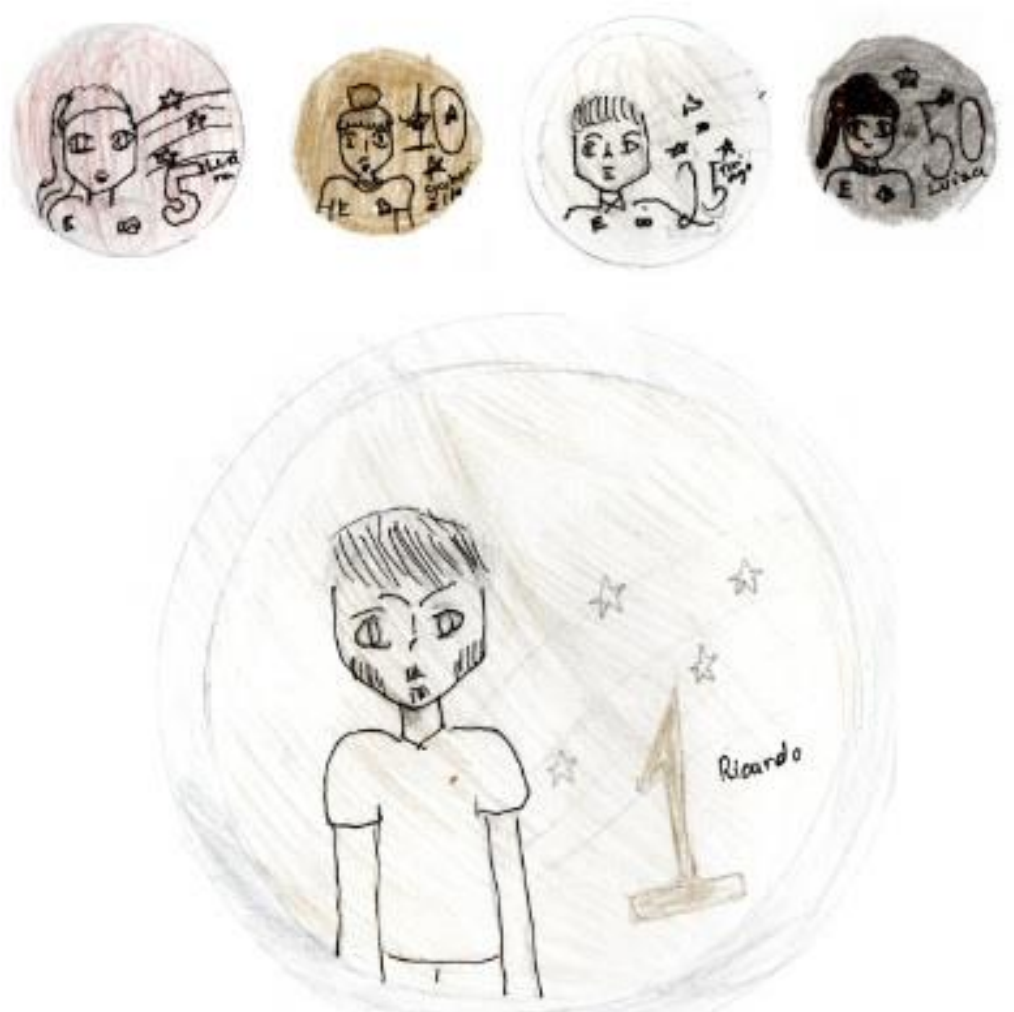

Figura 15 - Efígie dos próprios alunos e do professor nas novas moedas produzidas. 

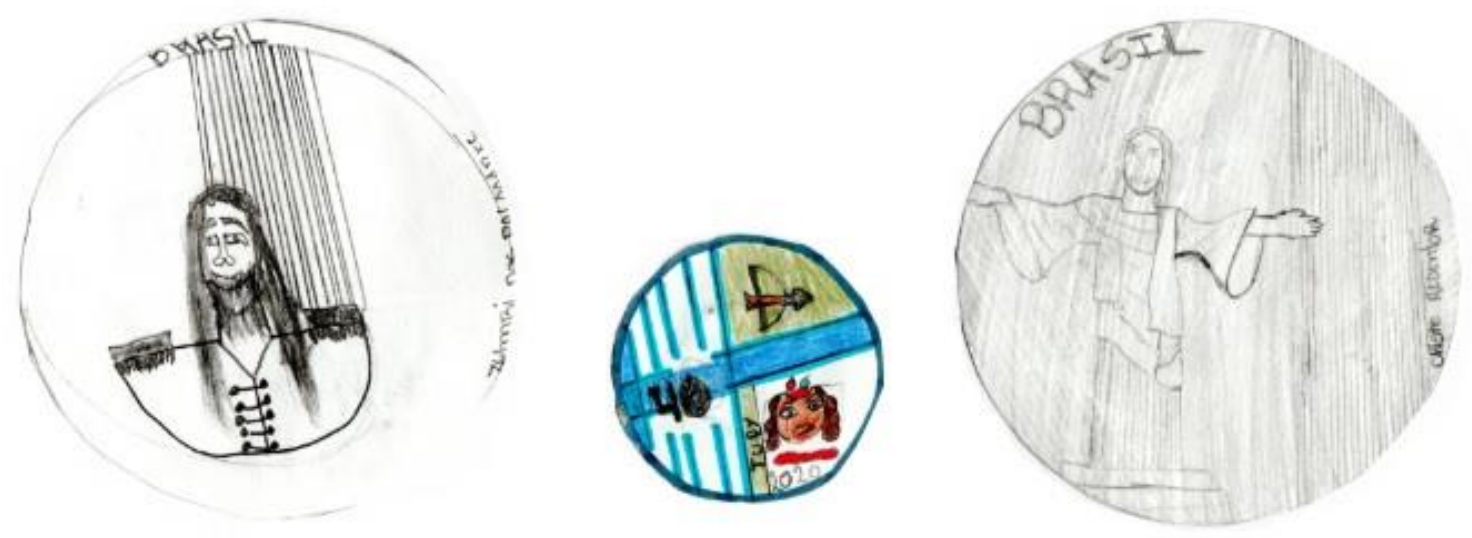

Figura 16 - Efígie de Zumbi dos Palmares, de um indígena Tupi, e do Cristo Redentor, respectivamente.

\section{Considerações sobre a atividade}

A metodologia da educação patrimonial desenvolvida por Horta et $a l^{149}$, aplicada a esta atividade se mostrou viável. $O$ passo a passo indicado pelo guia adaptado à atividade com as moedas foi uma forma didática de alcançar os objetivos propostos, ajudando os alunos a compreender melhor a proposição do trabalho. Embora a referida publicação apresente uma visão mais limitada a respeito do conceito de patrimônio cultural (cuja discussão mais ampla foi realizada no primeiro capítulo), quando aplicada a pesquisa, tal metodologia não apresentou problemas. Isto porque, compartilha-se da visão, neste trabalho, que é indiscutível a concepção da moeda enquanto patrimônio, não carecendo de um debate mais amplo sobre o seu caráter.

O ensino de História a partir do $6^{\circ}$ ano pode servir como oportunidade para provocar uma reflexão acerca da história oficialmente produzida, e a partir de

149 HORTA, Maria de Lourdes Pereira. GRUNBERG, Evelina. MONTEIRO, Adriane Queiroz. Guia

Básico de Educação Patrimonial. Instituto do Patrimônio Histórico e Artístico Nacional, museu Imperial,

1999. 
então considerar os múltiplos sujeitos que a compõem. A escolha das moedas como fonte para promover este propósito foi positiva na medida em que faz uso de algo presente no cotidiano discente e a partir disso proporcionar a construção do conhecimento em sala de aula. Assim, a atividade serve ao seu proposito na medida em que provoca esta reflexão no aluno a partir de uma abordagem historiográfica atual, colocando o ensino de História no mesmo patamar dos novos estudos $^{150}$.

Um dos fatores que facilitam essa viabilidade é o fato das aulas de História nos anos finais e ensino médio serem ministradas por licenciados em História, diferente dos anos iniciais que na maioria dos casos cabe ao professor pedagogo ou ao professor generalista, em nível de ensino médio oriundo do chamado curso normal, que não possui um aprofundamento nos estudos em termos de historiografia e de ensino de História. Cabe destacar que esta não é uma visão genérica, mas resultado de anos de observação, feita na unidade escolar em questão, onde o aluno inicia seus estudos desde a educação infantil e finaliza no $9^{\circ}$ ano do ensino fundamental. $\mathrm{O}$ fato de o aluno vir do $5^{\circ}$ ano com uma visão que glorifica figuras como a "libertadora" Isabel ou a do "descobridor" Cabral confirmam este argumento.

Esta visão é respaldada pelo trabalho de Oliveira ${ }^{151}$. Em sua pesquisa, a autora apresenta três fatores para justificar este descompasso apresentado no ensino de História entre os anos iniciais e finais. Primeiro, existe a falta de interesse por historiadores na promoção de pesquisas pautadas no processo de construção do conhecimento histórico em crianças. Segundo, existe uma lacuna na formação de professores dos anos iniciais quanto ao ensino de História, caracterizada pela desarticulação dos currículos entre as disciplinas pedagógicas e as de metodologia do ensino de História. Por fim, a não transposição das recentes pesquisas historiográficas aos livros didáticos de História, como já apresentado em debate anterior.

Em termos qualitativos, cabe ressaltar o nível de problematização entre os trabalhos produzidos entre o $6^{\circ}$ e o $8^{\circ}$ ano. Em sua maioria, os alunos do $6^{\circ}$ ano

\footnotetext{
${ }^{150}$ FANAIA, João Edson de Arruda. História, Saber Acadêmico e Saber Escolar: Um diálogo Possível? COLETÂNEAS DO NOSSO TEMPO, Rondonópolis - MT, v. VII, nº 8, p. 13 a 22, 2008.

${ }^{151}$ OLIVEIRA, Sonia Regina Ferreira. O ensino de história nas séries iniciais: cruzando as fronteiras entre a história e a pedagogia. História \& Ensino, Londrina, v. 9, p. 259-272, oul. 2003
} 
optaram por efígies deles próprios, enquanto os alunos do $8^{\circ}$ elegeram personagens com mais destaque na mídia ou profissões que merecem valorização. A problematização ocorreu dentro do esperado para cada faixa etária, seja a de crianças na faixa dos onze anos no início do ano, quanto aos de treze anos no final do ano letivo. Ambas as faixas de idade, dentro do seu nível de problematização, alcançaram o objetivo da atividade.

Importante ressaltar o uso de fontes complementares para a elaboração da atividade. Além do uso da numismática, a escolha por se trabalhar um sambaenredo foi acertada, pois a partir disso foi possível levar os alunos a compreenderem a aplicação da noção ampla do conceito de sujeitos históricos. Concorda-se, então, com os argumentos de Carvalho e Zampa quando propõem que o uso de fontes diversificadas auxilia no questionamento e na problematização das questões propostas ${ }^{152}$.

A atividade se mostrou mais produtiva quando aplicada no início do ano letivo. Neste momento do calendário escolar, os alunos estão mais dispostos e mais animados. Porém, isso não impede a sua aplicação em outros bimestres, o que vai depender do esforço do professor em promover a inclusão de todos os alunos no processo de ensino e aprendizagem. Independente do momento da aplicação, atividades inovadoras com o uso de fontes históricas devem ser proporcionadas sempre com o intuito de renovar a maneira de se ensinar História, tornando as aulas mais interessantes, desde que amparadas em critérios teóricos e metodológicos que justifiquem o seu uso.

\subsection{Atividade 2.}

Turma: 801 (2019)

A atividade foi aplicada na última semana do ano letivo de 2019 em uma turma de $8^{\circ}$ ano. Conforme consta na descrição da metodologia no segundo capítulo, o trabalho com a temática da Proclamação da República poderia ser aplicado tanto do final do ano letivo em turmas de $8^{\circ}$, quanto em turmas de $9^{\circ}$ ano no início do primeiro bimestre. Poucos alunos estavam presentes na aula, apenas

\footnotetext{
${ }^{152}$ CARVALHO, M. P. de. e ZAMPA, V. C. da S. O Arquivo Nacional na "Sala de Aula": fontes históricas na cons trução do conhecimento. Revista História Hoje, v. 6, n 12, p. 35-54 - 2017.
} 
cinco. Isso se deu devido ao fato de ser a última semana de aula, e a maioria dos que estavam aprovados resolveram antecipar o período de férias em uma semana.

Os alunos que estavam presentes, apesar de reclamarem, incialmente, por ter uma aula regular (mesmo com o período de provas e recuperações tendo sido finalizado), demostraram muito interesse e entusiasmo ao perceber que a atividade seria desenvolvida com moedas antigas. Seguramente, seria bom contar com a presença de toda a turma para a aplicação da atividade, porém como ela estava sendo aplicada pela primeira vez pelo professor, foi interessante ter um número reduzido de alunos como um caráter experimental.

Inicialmente, foi feito um pequeno resumo sobre o momento final do Império brasileiro, com foco nos aspectos iconográficos, bem como foram apresentados alguns símbolos referentes à República. Seguindo o plano elaborado para a aula, os alunos receberam diversas moedas que datavam do período monárquico, bem como dos anos iniciais da Primeira República. Eles fizeram o passo a passo orientado pelo professor, sendo o primeiro o da observação de todos os detalhes das moedas, com ênfase nos símbolos nelas representados. Em seguida, colocaram o material lado a lado, em ordem cronológica, separando-os também em dois grupos: pré e pós 1889. Estas etapas foram concluídas com sucesso, sem quaisquer dúvidas, e com demonstração de interesse e empenho.
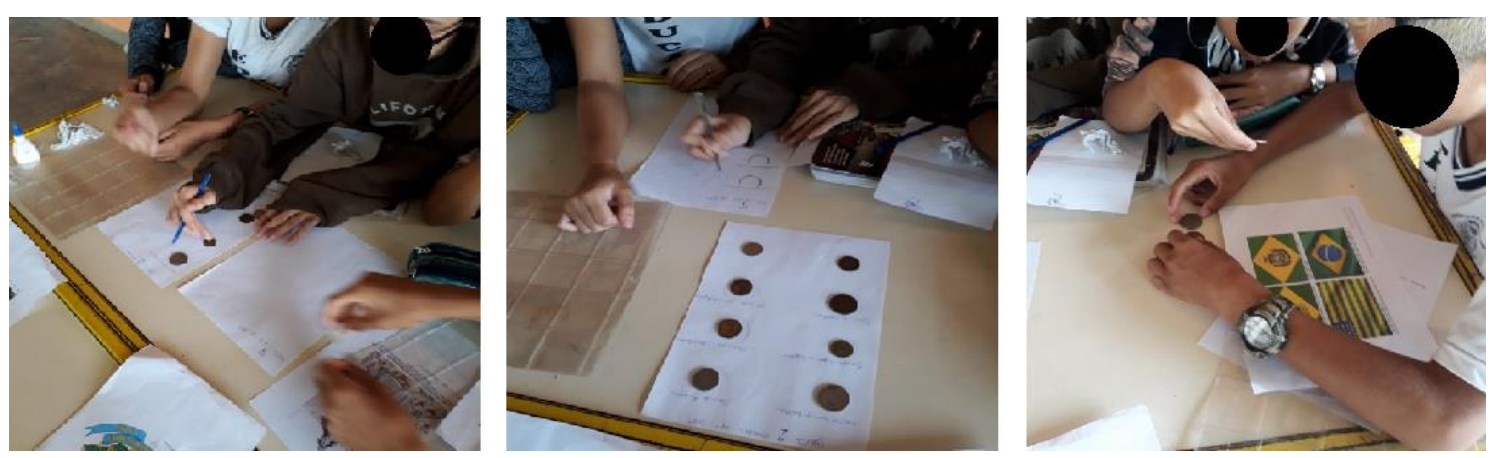

Figura 97 - Etapas da análise das fontes numis máticas.

O momento de formular as hipóteses sobre o motivo pelo qual ocorreram as mudanças nas simbologias cunhadas nas moedas a partir de 1889 foi feito por escrito. Optou-se por esta forma de avaliação escrita para que não se perdessem os registros feitos pelos alunos, o que poderia ocorrer caso o estímulo à reflexão fosse feita de forma oral A proposta inicial era que eles desenvolvessem estas 
hipóteses em grupo, porém como estavam presentes apenas cinco alunos, esta parte foi feita de forma individual a fim de se obter uma quantidade substancial de respostas.

Dos cinco resultados analisados, dois indicaram a hipótese de que a mudança dos símbolos nas fontes numismáticas foi resultado de um processo maior representado pela proclamação da República: "A diferença ou a mudança é que a forma de governar foi totalmente mudada [...]" e "Aconteceu que, com o passar dos anos, as mudanças do governo foram mudando e com isso as moedas também”. Outros dois alunos se preocuparam em descrever as características das moedas corretamente, e como elas mudaram, porém sem formular a hipótese pedida. E por último, um aluno não relacionou as mudanças dos símbolos com a hipótese pedida, mas o mesmo se empenhou em todas as etapas do trabalho. Todas as respostas produzidas encontram-se na íntegra, digitalizadas, no anexo dois desta pesquisa. Além das mudanças descritas, os alunos relataram oralmente a permanência de alguns símbolos entre as moedas como as coroas de café e fumo presentes tanto no brasão Imperial quanto no brasão Republicano.

$\mathrm{O}$ momento final da tarefa foi dedicado à guarda e a organização do acervo trabalhado de acordo com as dicas explicitadas no segundo capítulo desta pesquisa que versa sobre a guarda, limpeza e organização das fontes. Assim, os alunos produziram os próprios envelopes a partir de folhas de papel A4, colocando uma moeda em cada envelope. Após isso, cada envelope foi enumerado e foi feito o controle do material em uma lista contendo os respectivos números, bem como informações pertinentes a cada peça enumerada. Nesta parte, eles optaram por dividir as tarefas de acordo com as habilidades de cada um. Assim, dois alunos produziram os envelopes e outros fizeram a listagem com a enumeração e as informações sobre as moedas. 

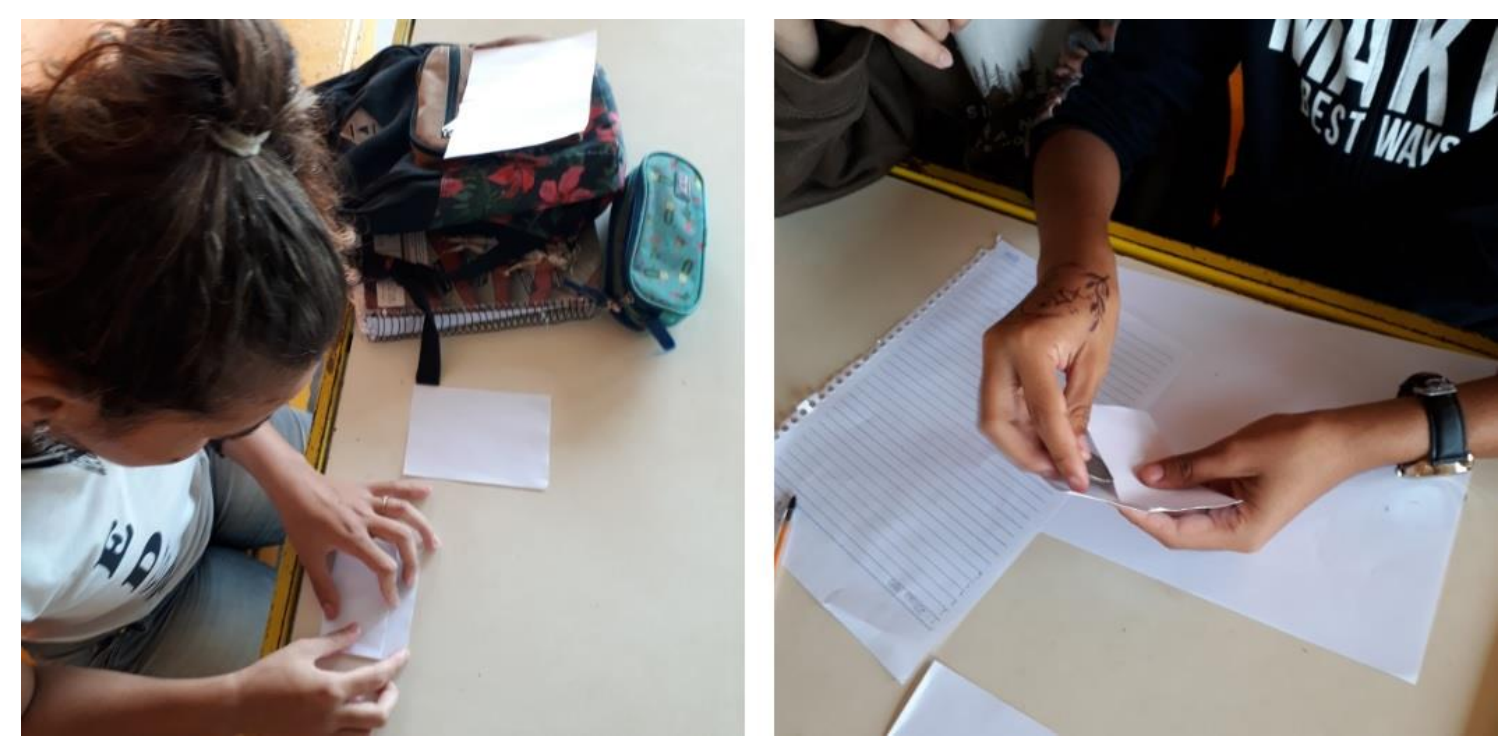

Figura 18 - Confecção dos envelopes e a organização do acervo estudado.

Quanto ao uso do aplicativo de celular indicado na proposta inicial, que serviria para organizar o acervo, não foi possível o seu uso, pois os alunos não estavam com o aparelho no momento da execução da atividade. $\mathrm{Na}$ escola existe uma regra muito rígida que proíbe o uso destes aparelhos no espaço escolar. É possível utilizá-lo em atividades didáticas, com prévia autorização dada pela equipe pedagógica da escola. Este pedido deveria ser feito pelo professor, mas devido à densa carga de trabalho no final de ano, este planejamento não foi realizado.

\section{Turma: 901 e 902 (2020)}

A atividade foi retomada no início do ano letivo seguinte, em 2020, com turmas de $9^{\circ}$ ano, conforme previsto no plano da aula. A análise dos resultados foi feita em conjunto, pois as turmas apresentavam características semelhantes quanto ao rendimento, tamanho, comprometimento e faixa etária. Desta vez, diferente da aplicação experimental do ano anterior, as turmas estavam presentes por completo e foi possível fazer uma observação mais detalhada, que permitiram melhores reflexões sobre as possibilidades do manejo de fontes numismáticas em sala de aula.

Inicialmente o conteúdo do ano anterior foi retomado como forma de revisão. Assim, a partir de aula expositiva os alunos relembraram os momentos finais do período imperial que culminaram na queda do governo e com a 
proclamação da República. Dentro desta aula também foram apresentadas as fontes iconográficas que serviriam para auxiliar na análise das moedas. Essas imagens foram levadas impressas pelo professor, facilitando que os alunos as consultassem posteriormente, pois foram colocadas sobre uma carteira para observação durante toda a atividade.

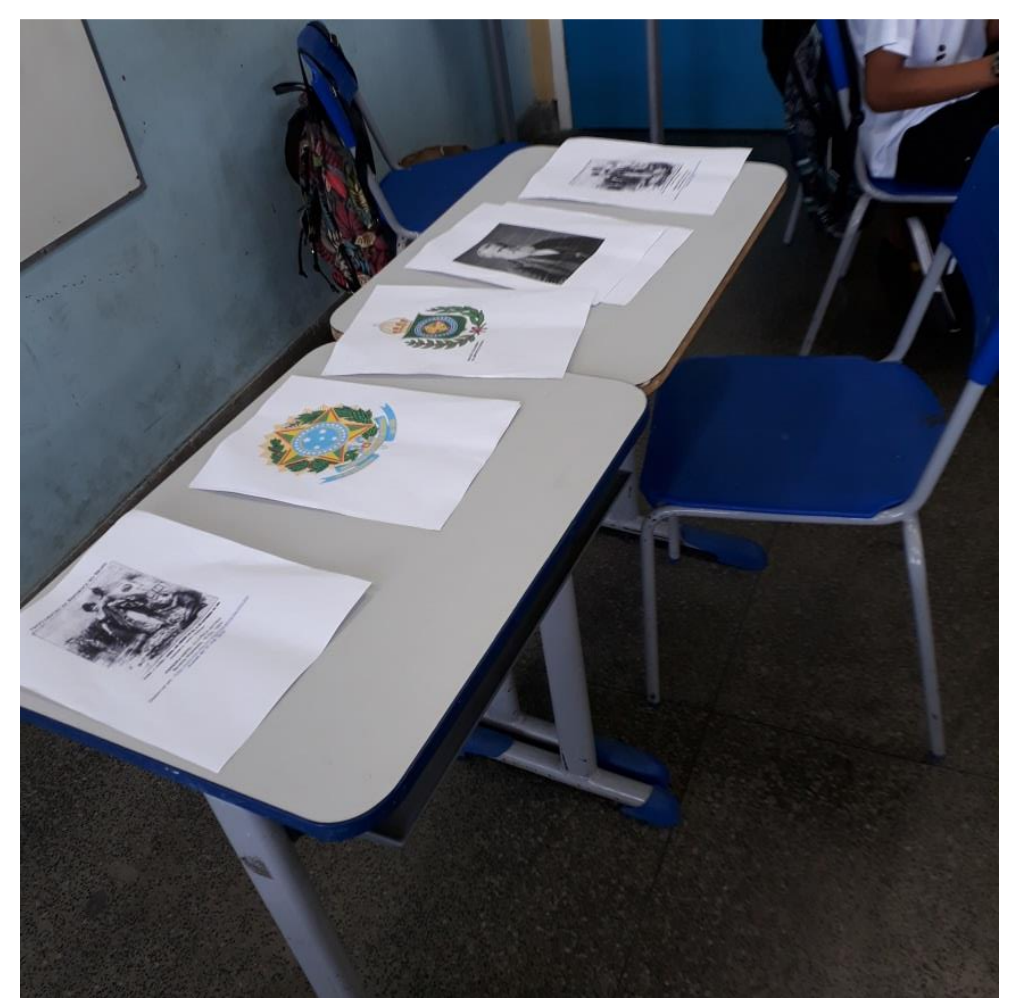

Figura 19 - Imagens postas sobre as carteiras para observação dos alunos.

Após o momento de revisão, o passo a passo da atividade foi explicado pelo professor para, em seguida, solicitar que eles se dividissem em grupos. Importante destacar que as experiências em atividades em grupo com crianças e adolescentes na faixa dos 11 aos 14 anos mostra que é mais viável primeiro explicar o trabalho, para depois pedir a organização dos grupos. Mais uma vez foi notável o quanto os alunos demonstram entusiasmo quando descobrem que o trabalho seria desenvolvido com a análise de moedas antigas que eles próprios iriam manusear.

O desenvolvimento das etapas transcorreu sem maiores problemas ou questões a serem relatadas, sempre com o apoio do professor percorrendo os grupos, respondendo a eventuais dúvidas e verificando o andamento dos trabalhos. Dos onze grupos organizados, apenas um não realizou a atividade. 
Sendo assim, no total foram obtidos dez resultados produzidos pelos grupos nas duas turmas analisadas. Destes dez trabalhos, oito conseguiram inferir que a mudança nos símbolos significou algo maior marcado pela transição política da Monarquia a República. Dois grupos não fizeram esta associação, mas identificaram corretamente a mudança na simbologia. Da mesma forma que no ano anterior, alguns grupos relataram ao professor a permanência de símbolos como as coroas de fumo e de café. Abaixo constam alguns dos resultados obtidos, sendo que digitalização dos trabalhos feitos se encontra por completo no anexo dois.

"Os símbolos mudaram pelo fato da mudança da monarquia para a república, então o governo quis mudança em tudo aquilo que se referia ao passado."

"Aconteceu a renovação da república e dos símbolos na moeda"

"De acordo com a mudança do governo, influenciou a mudança dos símbolos imperiais para os símbolos republicanos [...]"

“Com a mudança do governo os símbolos foram mudando, porque o rei (sic) foi perdendo poder de governar, pois os militares tomaram seus lugares e foram fazendo mudanças, tipo mudando os símbolos da bandeira e o hino, colocando o símbolo da república."

"Antes existia a monarquia e acabou, depois aconteceu a república, e com isso mudou os símbolos da moeda. Antes na moeda tinha a coroa em relação a monarquia, e com o fim houve a retirada da coroa."

"O Brasil deixou de ser comandado pelo Império e passou a ser uma república Federativa. Por isso houve a mudança dos símbolos."

\section{Considerações sobre a atividade}

De acordo com os resultados obtidos tanto nas turmas de $8^{\circ}$ ano quanto no $9^{\circ}$ ano, onde a maioria dos alunos correspondeu à análise correta das moedas, 
pode-se afirmar que o trabalho com fontes históricas possibilitou a construção do conhecimento histórico por eles. Isso foi possível devido à metodologia utilizada, por meio da qual foi prezado por não utilizar o documento como caráter de prova pelo que foi explicado pelo professor, e sim privilegiou-se um olhar sobre a fonte a partir de uma perspectiva crítica.

Embora alguns autores como Pereira e Seffner ${ }^{153}$ destaquem que as fontes não devem ser vistas apenas como forma de deixar as aulas mais atrativas, isso não pode ser desconsiderado dada a realidade do ensino público e a relação pouco positiva que, às vezes, os alunos estabelecem com a escola. Crê-se que atividades que atraem o olhar do aluno, ressignificando sua vontade de aprender devem ser incentivadas. Neste sentido, esta atividade também cumpriu o seu propósito dado à animosidade causada nos estudantes com a proposta de se trabalhar com moedas brasileiras do século XIX.

O momento do registro dos resultados pelos alunos, com a formulação das hipóteses, foi preferido fazê-lo por escrito para se ter maior amplitude das respostas produzidas e fazer as devidas reflexões. Esta escolha se deu porque aqui se trata de uma pesquisa acadêmica, sendo, portanto, fundamental ter todas as etapas de trabalho bem documentadas. Porém, para tornar a aula mais dinâmica, se for o caso de aplicar esta mesma atividade, o professor pode optar em apurar os resultados apenas de forma oral.

A proposta da atividade previa também o uso de um aplicativo de smartphones para fazer o registro do material analisado. Como visto na fundamentação teórica deste trabalho, assim como o uso de fontes em sala não deve ser uma fixação, e deve ser pensado a partir de um rigor metodológico e teórico, o uso de novas tecnologias devem seguir o mesmo caminho. Embora, aqui se tenha formulado uma proposta fundamentada para esse uso, o celular não foi utilizado, devido às dificuldades relatadas. Sendo assim, preferiu-se fazer o registro do material de forma manual, com o cadastramento das peças e a guarda em envelopes de papel.

O simples ato de guardar as moedas nos envelopes e registrá-las em uma folha foi positivo. Atitudes como essas, se sempre motivadas, desenvolvem no aluno o senso sobre a importância do cuidado com o patrimônio, o que foi

\footnotetext{
${ }^{153}$ Para saber mais, ver PEREIRA, N. M. e SEFFNER, F. O que pode o ensino de his tória? Sobre o uso de fontes na sala de aula. Anos 90, Porto Alegre, v. 15, n. 28, p.113-128, dez. 2008.
} 
percebido no cuidado e a dedicação na resolução desta etapa. Apesar do uso de novas tecnologias ser algo preconizado nos PCNs e na nova BNCC, em certos casos, na falta delas, o uso de métodos mais simples podem gerar bons resultados de igual forma.

Importante destacar questionamentos que surgiram ao longo da aplicação que não constavam no momento de planejamento da atividade. Como relatado, foi recorrente os alunos perceberem as permanências de elementos nos símbolos como as coroas de café e de fumo. A permanência destes símbolos nos dois brasões indica que, apesar da transição política, as estruturas econômicas do país se mantiveram e foram marcadas fortemente pela economia cafeeira. Sendo assim, uma proposta de aplicação futura da mesma atividade poderá considerar que os alunos percebam as rupturas e permanências nos símbolos cunhados nas moedas. Isso mostra que essa é uma proposta de trabalho que não é engessada, e é sempre proveitoso promover novas reflexões e abordagens, ficando a critério de cada professor adaptá-la a sua realidade.

\subsection{Atividade 3.}

Turma: 901 (2019)

A atividade foi aplicada em outubro de 2019, em uma turma de $9^{\circ}$ ano. Foi pedido que a turma se organizasse em duplas, com a sugestão dada pelo professor de que se formassem as duplas com colegas próximos. Esse pedido visou dinamizar a aplicação da tarefa, visto que o plano da aula prevê a duração de vinte minutos, compreendendo todas as etapas do trabalho, que vai da organização da turma, explicação da proposta, entrega do material utilizado, e apuração dos resultados.

Foram formadas quatorze duplas no total e cada dupla recebeu o montante de seis moedas para a análise, sendo uma necessariamente datada do período do Estado Novo, cuja efígie traz a figura de Getúlio Vargas. Embora o plano da aula previsse um total de dez a quinze moedas a serem entregues a cada dupla, no momento da aplicação foi preferível o número de seis visando novamente dinamizar a tarefa. Verificou-se que esse número é adequado para uma proposta de análise rápida, porém pode ser feita com mais fontes caso o professor deseje dedicar mais tempo ao processo de análise das fontes pelos alunos. 
Em relação às demais fontes selecionadas, como o foco do trabalho era correlacionar o culto a imagem do presidente Vargas como uma estratégia de propaganda fazendo a associação da sua efígie na moeda, as demais moedas selecionadas continham, necessariamente, efígies de outras personalidades para tornar a tarefa da observação mais desafiadora, conforme mostra a imagem abaixo. Uma possibilidade para o professor que não disponha da quantidade adequada de moedas com efígies para a atividade, em torno de noventa para uma turma com trinta alunos, a solução é levar as moedas impressas em papel, como sugerido no primeiro capítulo desta dissertação.

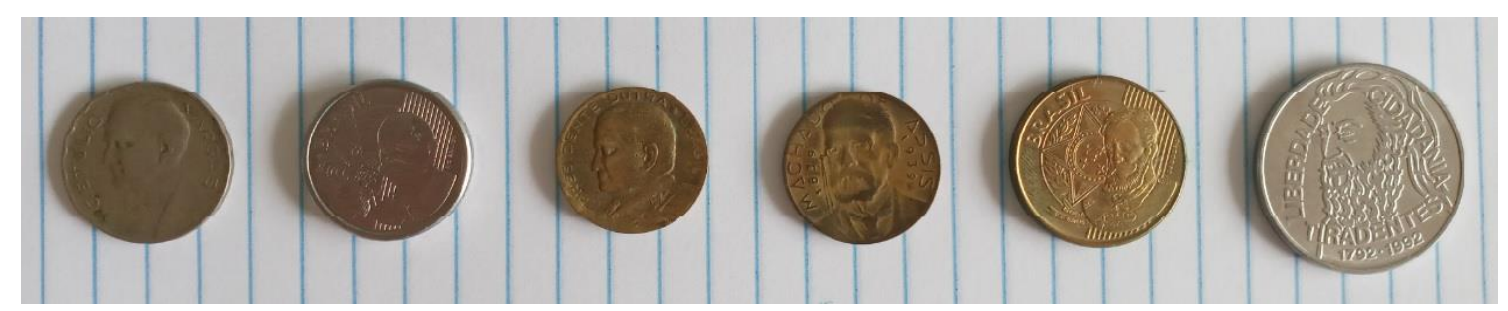

Figura 20 - Um dos conjuntos de moedas analisadas pelos alunos. As efígies retratadas da esquerda para a direita: Getúlio Vargas (1938), Barão do Rio Branco (2010), Eurico Gaspar Dutra (1956), Machado de Assis (1939), Deodoro da Fonseca (2008) e Tiradentes (1992).

Novamente, foi notável o entusiasmo que a turma apresentou ao perceber que o trabalho seria realizado com moedas antigas. Alguns alunos sinalizaram ao professor que tinham moedas antigas em casa e que trariam na próxima aula, o que ocorreu. Os alunos receberam a listagem com os presidentes de todo o período republicano com a respectiva data de duração do mandato. Eles tiveram facilidade ao identificar que a presença da efígie do presidente Getúlio Vargas na moeda foi contemporânea ao seu período de mandato, entre 1937 e 1945, tempo em que perdurou o Estado Novo.

Ao serem estimulados oralmente a formular hipóteses para a constatação anterior, os alunos que responderam, conseguiram compreender que o recurso utilizado pelo governo ao cunhar moedas do próprio presidente se configurou em uma estratégia de culto a imagem do líder. As respostas foram anotadas pelo professor a fim de melhor avaliar os resultados obtidos. Algumas duplas responderam que: "Ele [o presidente] queria se promover"; "Eu acho que ele 


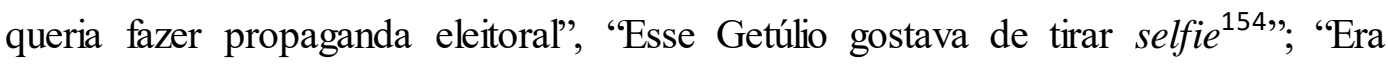
propaganda política".

Nem todas as quatorze duplas responderam ao professor. A apuração das formulações das hipóteses de forma oral foi adotada convergindo com a ideia de ser uma atividade rápida, porém essa forma dos alunos exporem suas ideias não contemplou toda a turma. Alguns demonstraram mais timidez, outros reconheceram o mesmo pensamento na fala dos colegas e preferiram não opinar, e houve os que não conseguiram desenvolver a análise.

Por ser tratar de uma pesquisa acadêmica, as respostas poderiam ter sido feitas por escrito, como feito adequadamente na atividade dois, por exemplo. Por ela ter sido a primeira atividade aplicada, realizada em outubro de 2019, essa ideia ainda não tinha sido desenvolvida no plano para a aula, o que foi um equívoco, pois não foi possível ter uma visão do todo, e sim apenas a apuração de algumas duplas. Isso poderia ter sido corrigido na sua segunda aplicação no ano de 2020, mas devido à pandemia do Covid-19 e a interrupção das aulas presenciais, isto não foi possível.

Se a ideia for realizar uma atividade introdutória da Era Vargas de forma dinâmica, a exposição das ideias dos alunos oralmente pode continuar sendo feita. Neste sentido, o tempo de 20 minutos previsto foi adequado. Mas se o professor preferir utilizar mais moedas para a análise e que os alunos exponham suas ideias por escrito, a atividade deve durar em torno de 30 a 35 minutos para a sua conclusão.

\section{Considerações sobre a atividade}

Os resultados analisados foram positivos ao confirmar que os alunos conseguiram inferir, através da análise numismática, que a imagem de Getúlio Vargas na moeda representa uma forma de culto a sua imagem. Mesmo os alunos que não fizeram essa afirmação diretamente, percebe-se que houve a compreensão da historicidade, como o que disse que o presidente gostava de selfie. Neste caso, acredita-se que ele associou a ideia do autorretrato como uma forma de Vargas se valorizar, tal como os jovens fazem hoje em dia nas redes sociais. Obviamente

\footnotetext{
${ }^{154}$ Selfie é uma fotografia, geralmente digital, que uma pessoa tira de si mesma (autorretrato).
} 
não se espera que os alunos nesta faixa etária tragam uma resposta a nível acadêmico, ou que se utilizem de termos fora da sua realidade como "culto à imagem", por exemplo.

A estratégia de propor este trabalho como uma introdução ao Estudo da Era Vargas também foi positiva, pois foi possível atrair a atenção dos alunos para o tema de estudo, com o foco em uma das características do que iria vigorar no Estado Novo que foi a propaganda. Assim, concorda-se com o argumento de Bittencourt ${ }^{155}$ exposto na discussão teórica quando diz que além do seu caráter informativo e atrativo, as fontes podem ser utilizadas para a introdução das aulas sendo também trabalhadas devidamente de maneira crítica.

A questão do olhar sobre a fonte, a partir de uma perspectiva crítica também merece destaque. Na atividade, o aluno precisou decodificar as informações contidas no documento para chegar a uma conclusão a partir da inferência, trabalhando a fonte muito além do sua função validadora do que foi dito pelo professor. Desta forma, concorda-se com as ideias dos autores discutidos, como Pereira e Seffner, quando dizem, por exemplo, que o "uso de fontes históricas deve servir para suspender o caráter de prova que os documentos assumem desde a História tradicional e mostrar às novas gerações a complexidade da construção do conhecimento histórico "156.

\subsection{Atividade 4.}

A atividade quatro foi aplicada junto a turma 901 em dezembro de 2019, na última semana do ano letivo. Assim como a atividade dois, esta também foi aplicada em caráter experimental visto que apenas sete alunos estavam presentes na aula. Outra questão, é que devido a grande quantidade de conteúdo destinado a disciplina no $9^{\circ}$ ano, tendo que trabalhar temas do século $\mathrm{XX}$, no mundo e no Brasil, em muitas situações o estudo do período militar é prejudicado visto que ele é um dos últimos a ser trabalhado. Por esta razão, o tema foi abordado justamente

\footnotetext{
${ }^{155}$ BITTENCOURT, Circe. Ensino de História: fundamentos e métodos. $4^{\text {a }}$ ed. São Paulo: Cortez, 2011. p. 30.

${ }^{156}$ PEREIRA, N. M. e SEFFNER, F. O que pode o ensino de história? Sobre o uso de fontes na sala de aula. Anos 90, Porto Alegre, v. 15, n. 28, p.113-128, dez. 2008. P. 126.
} 
no último mês do ano letivo, sendo a atividade aqui relatada o desfecho de todo o assunto estudado.

Inicialmente foi feita a explanação da atividade e todas as suas etapas detalhadamente antes de dividir a turma em grupos, evitando conversas paralelas. Como havia poucos alunos na aula, foram formados dois grupos com quatro e três integrantes. Cada grupo recebeu quinze moedas de Cruzeiro datadas dos anos de 1964 a 1985. Para um turma com uma média de trinta alunos, estima-se que com cem moedas do período é possível executar a tarefa de forma adequada oferecendo um quantitativo de fontes suficientes para cada grupo analisar. É valido lembrar que moedas de Cruzeiro deste período não são raras, sendo fácil de adquiri-las pelos meios expostos no primeiro capítulo, e de armazená-las visto que o aço inox é uma matéria-prima extremamente resistente.

Destaca-se novamente o entusiasmo que os alunos demonstraram pelo trabalho com moedas de outros tempos. Relatos de que eles possuem moedas antigas em casa também foram comuns. Neste caso pode-se sugerir, na aula anterior, que eles levem suas próprias moedas, se tiverem o interesse de buscar em casa junto a familiares, as fontes da época trabalhada. Isso objetiva tornar a análise mais atrativa utilizando-se de algo que lhes pertence, atribuindo novos sentidos a peça guardada, além de ampliar o desejo em preservá-la.

Os alunos receberam a tabela para guiá-los na elaboração da atividade. Ela pode ser encontrada junto ao guia no primeiro anexo desta dissertação, na seção referente a atividade quatro. Isso facilitou a sua condução, pois na tabela continham os três passos da proposta fazendo com que eles não apresentassem dúvidas. A primeira etapa consistiu em separar as moedas em grupo de acordo com cada momento do período militar observando a data de cunhagem. Os alunos não apresentaram dúvidas ou dificuldades na execução desta parte.

A segunda etapa consistiu em completar as tabelas com as informações pedidas. Eles conseguiram identificar os menores e maiores valores das moedas sem dificuldades. No momento do cálculo percentual em que eles deveriam calcular a variação dos maiores valores em relação ao período anterior eles apresentaram muitas dúvidas. Finalizando esta etapa, no momento da identificação do contexto econômico eles conseguiram fazer sem problemas, visto que todos tinham o conteúdo no livro didático e no caderno e puderam consultálo. 
Por fim, na terceira etapa, os alunos tiveram que relacionar os contextos econômicos com a variação percentual das moedas de maior valor para entender o processo inflacionário vivido naquela época. Nesta parte eles também apresentaram muitas dúvidas e foi necessária a intervenção do professor para auxiliá-los na construção das correlações. Assim, com a ajuda do professor, conseguiram perceber que a mudança no valor das moedas representou um processo inflacionário e que isso foi o indicativo da crise econômica vivida no último decênio do regime militar. Os dois grupos entregaram a tabela completa que pode ser encontrada junto ao anexo três desta dissertação.

\section{Considerações sobre a atividade.}

Novamente, assim como ocorreu com o trabalho sobre a Era Vargas, a interrupção das aulas por causa da pandemia impossibilitou a aplicação da mesma atividade na turma de $9^{\circ}$ ano em 2020. Mesmo não sendo possível testá-la novamente, os resultados obtidos na única aplicação permitiram uma visão geral sobre a proposta a partir de experiências positivas e negativas.

O trabalho com fontes numismáticas mais uma vez se mostra original, desafiador e atrativo. Foi visível a animação e interesse dos alunos com o estudo das moedas da época. Esta também foi uma oportunidade de testar como o trabalho com fontes complementares conversam entre si e ajudam os alunos a ter uma compreensão mais ampla do momento econômico vivido a época do regime militar. No caso, na aula anterior foram mostrados recortes de jornais da época que mostravam as manifestações do Movimento Contra a Carestia. Com isso, esta pesquisa vem a concordar com os autores ${ }^{157}$ citados no primeiro capítulo que salientam a importância do trabalho com fontes que se complementam durante o processo de construção do conhecimento histórico.

Desta vez, os alunos apresentaram muitas dificuldades na realização de algumas etapas como o calculo percentual e a parte final onde deveriam associar a alta inflacionária percebida nas moedas com a crise do período. Embora o

\footnotetext{
${ }^{157}$ Para saber mais, ver CARVALHO, M. P. de. e ZAMPA, V. C. da S. O Arquivo Nacional na "Sala de Aula": fontes históricas na construção do conhecimento. Revista História Hoje, v. 6, n 12, p. 35-54 - 2017.
} 
conteúdo de porcentagem esteja presente na nova BNCC para o $9^{\circ}$ ano, e tendo o professor da disciplina ensinado este tema aos alunos, pareceu que o assunto ainda não estava consolidado, o que não é um grande problema, pois os temas serão retomados e aprofundados durante o ensino médio. Em relação à parte final, foi preciso que o professor guiasse os alunos durante esse processo de reflexão, o que fugiu da proposta inicial em que os alunos deveriam construir o conhecimento de forma mais autônoma.

Para esta atividade alguns conceitos deveriam ter sido trabalhados com mais profundidade, como o caso da inflação. Ainda assim, a atividade atingiu um nível de complexidade alto dado o problema com o cálculo matemático e a reflexão final. Pensando nisso, para esta atividade, da forma como foi proposta, sugere-se que seja destinada a turmas do $3^{\circ}$ ano do ensino médio, onde alguns conceitos estariam mais consolidados, além de ser possível trabalhar o contexto da ditadura militar com mais profundidade. 


\section{Considerações finais}

Nesta pesquisa testou-se a viabilidade do uso da numismática como um instrumento que proporcione um eficaz processo de ensino e aprendizagem em História. A partir de uma série de atividades aplicadas, analisadas e discutidas, inseridas dentro de uma perspectiva teórica aprofundada, bem como uma base metodológica ampla, foi possível chegar a algumas conclusões.

Embora se tenha destacado que o uso de fontes em sala de aula deve ter como foco o processo de construção do conhecimento histórico indo além de tornar a aula atrativa, esse é um fator que não pode ser esquecido. Foi recorrente os alunos demonstrarem grande entusiasmo ao saber que na aula iriam trabalhar com moedas antigas. Por muitas vezes eles se veem desmotivados com um modelo tradicional de ensino onde o professor é o centro das atenções e os alunos meros espectadores. Em outros casos até a própria estrutura física da escola pública é um fator desestimulante para o processo de ensino e aprendizagem. Sendo assim, o uso de um elemento diferenciado, como a numismática, promoveu exatamente uma aula mais estimulante e atrativa, e isso deve ser considerado como algo primordial para a escolha deste método de estudo nas aulas de História.

Esta metodologia apresentada através das atividades, apesar do roteiro estabelecido, também se mostrou maleável durante a sua execução. Em momentos que foram necessários ajustes levando em consideração a configuração das turmas, a estrutura, a disponibilidade das fontes, e a época de aplicação, não interferiram substancialmente na produção de resultados satisfatórios. Assim, conclui-se que o uso da numismática como recurso didático pode ser utilizada pelos professores de História, cabendo ao profissional adaptar a metodologia de acordo com a sua realidade considerando as diversas variáveis da sua prática pedagógica.

O conhecimento histórico produzido pelos alunos partiu das premissas abordadas na fundamentação teórica da pesquisa adaptadas a realidade da educação básica. Neste sentido, cabe destacar a metodologia da educação patrimonial na construção dos saberes em sala de aula. Conceber a moeda como um patrimônio cultural e a partir disso elaborar as atividades focadas com o 
propósito de valorizá-la possibilitou maior aproximação do educando com a produção de novos conhecimentos a partir de algo presente na sua realidade.

A proposta mostrou também a efetividade do uso do documento histórico de forma crítica, e não somente como uma confirmação de algo dito pelo professor. Independente do momento da aula onde a metodologia foi utilizada, seja no início para a introdução de um assunto, durante a aula somada a fontes complementares, ou no final como forma avaliativa, os resultados das atividades demonstraram que os alunos conseguiram construir o conhecimento histórico mediante a análise das moedas a partir da mediação do professor. Evidentemente que o conhecimento construído esteve dentro das suas possibilidades enquanto estudantes dos anos finais do ensino fundamental, e não em nível acadêmico.

Questões sobre a análise de fontes históricas na sala de aula trazem a reflexão sobre a importância desta pesquisa no sentido de contribuir para a construção de um diálogo entre os saber acadêmico e o saber escolar. Promover uma abordagem que privilegiou a aproximação destes dois saberes foi possível, principalmente, pela proposta do programa de mestrado em ensino de História, cuja dissertação está inserida. O PROFHISTÓRIA tem um olhar voltado para a inovação em sala de aula a partir de uma reflexão crítica acerca de questões que envolvem o ensino de História e Historiografia. O resultado deste trabalho é reflexo do que foi apreendido no programa, seja através do currículo inovador, dos professores engajados, da orientação acadêmica presente, mesclado à bagagem dos discentes que vivem o dia-a-dia da educação básica, contribuindo para reduzir a distância entre o chão da escola e o conhecimento oriundo da academia.

Também se constata que foi positivo inserir a proposta de trabalho a partir das bases lógicas do conhecimento científico. A ideia de testar as atividades mais de uma vez, em momentos e turmas diferentes, foi importante neste sentido, apesar de terem ocorridos contratempos que impossibilitaram mais aplicações. Assim, a partir da experimentação, de tentativas acertadas e equivocadas, e considerando diversas variáveis, foi possível avaliar como produtivo todo o processo utilizando a numismática nas aulas de História.

Pensando pela perspectiva dos alunos, promover atividades pautadas na lógica cientifica é o caminho para se promover sua autonomia. Os trabalhos com a numismática, inseridos dentro deste viés, foram importantes por irem contra o 
modelo de ensino pautado apenas no ato de repetir e reproduzir pelos estudantes, mas sim valorizando a construção crítica do conhecimento sob as bases da lógica científica a partir de atividades produzidas por meio de discussões teóricas e metodologias fundamentadas. Estimular o processo de ensino e aprendizagem desta forma, além de proporcionar o desenvolvimento autônomo discente, democratiza o acesso e o desenvolvimento da ciência na escola pública brasileira.

Por fim, destaca-se a relevância da afirmação posta nesta pesquisa que coloca a sala de aula como um espaço onde o aluno é o sujeito da construção de saberes. O uso escolar da numismática neste processo foi fundamental é deve-se ressaltar a sua originalidade e importância para a confirmação das questões e dos objetivos propostos no trabalho. 


\section{Referências bibliográficas}

ALBUQUERQUE Jr, D.M. de. Regimes de historicidade: como se alimentar de narrativas temporais através do ensino de História, $\mathbb{I N}$ : GABRIEL, C.T.;MONTEIRO, A.M.; MARTINS M.B. Narrativas do Rio de Janeiro nas aulas de História. Rio de Janeiro: Mauad X , 2016.(19-42)

ALVES, Aline Neves Rodrigues. Comunidade Quilombo de Santana. Belo Horizonte : FAFICH, 2016.

BITTENCOURT, Circe Maria Fernandes. Ensino de história: fundamentos e métodos. $2^{\mathrm{a}}$ edição. Editora Cortez. São Paulo, 2008.

BOULOS JUNIOR, Alfredo. História: sociedade e cidadania. $9^{\circ}$ ano. São Paulo: FTD, 2016.

BRASIL. Ministério da Educação. Secretaria da Educação Básica. Base nacional comum curricular. Brasília, DF, 2016.

Parâmetros curriculares nacionais: história/Secretaria de Educação Fundamental. Brasília : MEC /SEF, 1998.

BURKE, Peter. A Escola dos Annales (1929-1989): a Revolução Francesa da Historiografia. São Paulo: Fundação Editora da UNESP, 1997.

CAIMI, Flávia Eloísa. Fontes históricas na sala de aula: uma possibilidade de produção de conhecimento histórico escolar? Anos 90, Porto Alegre, v. 15 , n. 28, p. $129-150$, dez. 2008.

CARDOSO, Ciro Flamarion; VAINFAS, Ronaldo. (Orgs.). Domínios da História: ensaios de teoria e metodologia. Rio de Janeiro: Campus, 1997.

CARLAN, C. U. "Arqueologia e Numismática: A História Antiga e a Cultura Material". Agenda social (UENF), v.4, 2010. p. 22-36.

Moeda e poder em Roma: um mundo em transformação. São Paulo: Annablume, 2013.

; FUNARI, P. P. A. Moedas, a Numismática e o estudo da História .1. São Paulo: Annablume/Fapemig/Unifa//Unicamp, 2012.

CARVALHO, M. P. de. e ZAMPA, V. C. da S. O Arquivo Nacional na "Sala de Aula": fontes históricas na construção do conhecimento. Revista História Hoje, v. 6, n 12, p. 35-54- 2017. 
CORDEIRO, Janaina Martins. As comemorações do Sesquicentenário da Independência em 1972: uma festa esquecida? Anais do XXVI Simpósio Nacional de História - ANPUH • São Paulo, 2011.

COSTILHES, Alain Jean. 0 que é numismática. Editora brasiliense. São Paulo, 1985.

FAGUNDES, Luciana Pessanha. De volta à terra pátria: o translado dos restos mortais de D. Pedro II e Thereza Cristina para o Brasil (1921). XXVVIII Simpósio Nacional de História, Florianópolis, 2015.

FANAIA, João Edson de Arruda. História, Saber Acadêmico e Saber Escolar: Um diálogo Possível? COLETÂNEAS DO NOSSO TEMPO, Rondonópolis - MT, v. VII, nº 8, p. 13 a 22, 2008.

FAUSTO, Boris. História concisa do Brasil. São Paulo: Edusp/lmprensa Oficial do Estado, 2001.

FEBVRE, Lucien. Combates pela história. $3^{\text {a }}$ ed. Lisboa, Editorial Presença, 1989.

GALANTE, Luís Augusto Vicente. Uma História da circulação monetária no Brasil do Século XVIII. Tese de Doutorado. UNB. Brasília, 2009.

GALLAS, Alfredo; GALLAS Fernanda Disperati. As moedas contam a história do Brasil. São Paulo. Magma Editora Cultural, 2007.

HORTA, Maria de Lourdes Pereira. GRUNBERG, Evelina. MONTEIRO, Adriane Queiroz. Guia Básico de Educação Patrimonial. Instituto do Patrimônio Histórico e Artístico Nacional, museu Imperial, 1999.

JUNIOR, Amaury Fernandes. Uma etnografia do dinheiro: os projetos gráficos de papel-moeda no Brasil após 1960. Tese de Doutorado. UERJ. Rio de Janeiro, 2008.

JURT, Joseph. O Brasil: Um Estado-Nação a ser construído. O papel dos símbolos nacionais, do Império à República. Revista Mana, vol.18, nº 3 . Rio de Janeiro, 2012.

KNIVET, Anthony. As incríveis aventuras e estranhos infortúnios de Anthony Knivet (1591). Organização, introdução e notas: Sheila Moura Hue. Rio de Janeiro: Jorge Zahar, 2007.

LE GOFF, Jacques. Documento / Monumento. In: Enciclopédia Einaudi. V. 1. Lisboa: Imprensa Nacional - Casa da Moeda, 1984. 
História e Memória. Tradução de Bernardo Leitão.

Campinas, Editora Unicamp, 2003

MALDONADO, Rodrigo. Catálogo de moedas brasileiras. 1500 - 2017. Quinta Edição. 2017.

OLIVEIRA, Sonia Regina Ferreira. O ensino de história nas séries iniciais: cruzando as fronteiras entre a história e a pedagogia. História \& Ensino, Londrina, v. 9, p. 259-272, out. 2003.

PEREIRA, N. M. e SEFFNER, F. O que pode o ensino de história? Sobre 0 uso de fontes na sala de aula. Anos 90, Porto Alegre, v. 15, n. 28, p.113-128, dez. 2008.

RAMOS, Mariana Contin. Com Vargas no bolso: o meio circulante brasileiro como ideologia e propaganda do Estado Novo. Dissertação de mestrado. UNIRIO. Rio de Janeiro, 2015.

VIEIRA R. M. L. Alguns princípios gerais de conservação de moedas e o processo de limpeza mecânica adotado no Museu Histórico Nacional. Rev. do Museu de Arqueologia e Etnologia, São Paulo, 2:133-136, 1992.

\section{Sites Web utilizados}

Artigo 37, Parágrafo $1^{\circ}$ da CF de 1988, Disponível em: $<$ https://www.senado.leg.br/atividade/const/con1988/CON1988 05.10.198 8/art 37.asp> Acesso em: 16 de jan. de 2020.

Biblioteca PUC-Rio. Disponível em: <http://www.dbd.puc-rio.br/sitenovo/>

BNCC. Disponível em:

$<$ http://basenacionalcomum.mec.gov.br/abase/\#fundamental/historia-no-

ensino-fundamental-anos-finais-unidades-tematicas-objetos-deconhecimento-e-habilidades acesso em 27/12/2019> Acesso em: 15 de dez. de 2019.

Caravelas coleções. Disponível em: $<$ https://materiais.caravelascolecoes.com.br/como-limpar-moedas acesso em 03/04/2020 > Acesso em: 18 de jan. de 2020.

Catálogo Moedas do Brasil. Disponível em: $<$ http://www.moedasdobrasil.com.br/moedas/> 
Decreto $\mathrm{n}^{0}$ 155-B de 14 de janeiro de 1890. Disponível em: $<$ https://www2.camara.leg.br/legin/fed/decret/1824-1899/decreto-155-b14-janeiro-1890-517534-publicacaooriginal-1-pe.html> Acesso em: 16 de jan. de 2020.

Decreto № 54-B, de 13 de dezembro de 1889. Disponível em: $<$ https://www2.camara.leg.br/legin/fed/decret/1824-1899/decreto-54-b-13dezembro-1889-504306-publicacaooriginal-1-pe.html> Acesso em: 16 de jan. de 2020.

Decreto o 60.190, de 8 de fevereiro de 1967 instituiu o Cruzeiro Novo. Disponível em: <https://www2.camara.leg.br/legin/fed/decret/19601969/decreto-60190-8-fevereiro-1967-401727-publicacaooriginal-1-

pe.html> Acesso em: 21 de abr. de 2020.

IBGE.

Disponível

em:

$<$ https://cidades.ibge.gov.br/brasil/ri/quatis/panorama> Acesso em 13 de nov. de 2019.

IBGE.

Disponível

em:

$<$ https://cidades.ibge.gov.br/brasil/ri/quatis/pesquisa/23/22957?detalhes=tr ue> Acesso em 13 de nov. de 2019.

IPHAN. Disponível em: <http://portal.jphan.gov.br/pagina/detalhes/218> Acesso em: 16 de nov. de 2018.

Jstor. Disponível em: <https://www.jstor.org/>

Mercado Livre. Disponível em: <https://www.mercadolivre.com.br/>

Mestrado profissional em ensino de história (PUC-Rio). Disponível em: $<$ http://www.his.puc-rio.br/pos-graduacao/prof-hist-capes/> Acesso em: 26 de fev. de 2020.

Mestrado profissional em ensino de história (UERJ). Disponível em: $<$ https://www.vestibular.ueri.br/?page id=7763> Acesso em: 11 de abr. de 2020.

Moedas com maior valor facial no Brasil. Disponível em: $<$ http://www.moedasdobrasil.com.br/moedas/ranking.asp\#facialR $>$ Acesso em 16 de jan. de 2020.

Museu Histórico Nacional: Disponível em: $<$ https://mhn.museus.gov.br/index.php/acervo/> Acesso em: 17 de mar. De 2020.

Periódicos Capes. Disponível em: <http://www.periodicos.capes.gov.br/>

Portal da transparência - Quatis. Disponível em: $<$ http://transparencia.quatis.ri.gov.br/> Acesso em 13 de nov. de 2019. 
Prefeitura Municipal de Quatis. Disponível em: $<$ http://quatis.ri.gov.br/historia/> Acesso em: 13 de nov. de 2019.

Scielo. Disponível em: <http://www.scielo.org/php/index.php > 
ANEXO 1

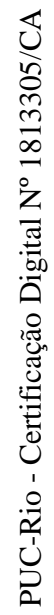




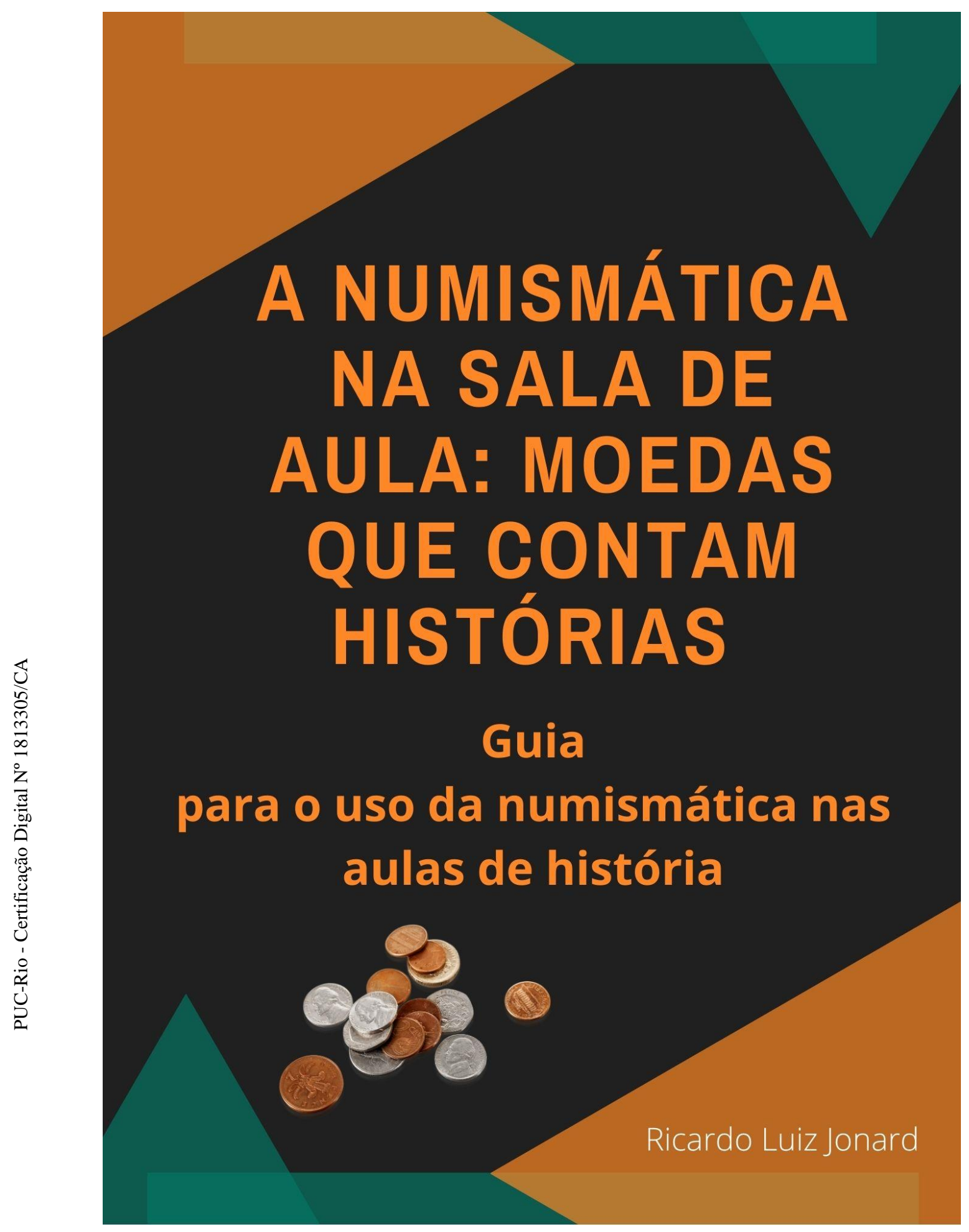




\title{
A numismática na sala de aula: moedas que contem histórias
}

\author{
Guia \\ para o uso da numismática \\ nas aulas de História
}
Apoio:
Guia elaborado a partir da dissertação de mestrado intitulada "A Numismática na sala de aula: moedas que contam histórias" inserida no programa de mestrado profissional em Ensino de História (PROFHISTÓRIA)
Autor: Ricardo Luiz Jonard

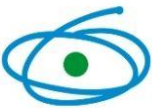
Orientadora: Juçara da Silva Barbosa de Mello
CAPES 


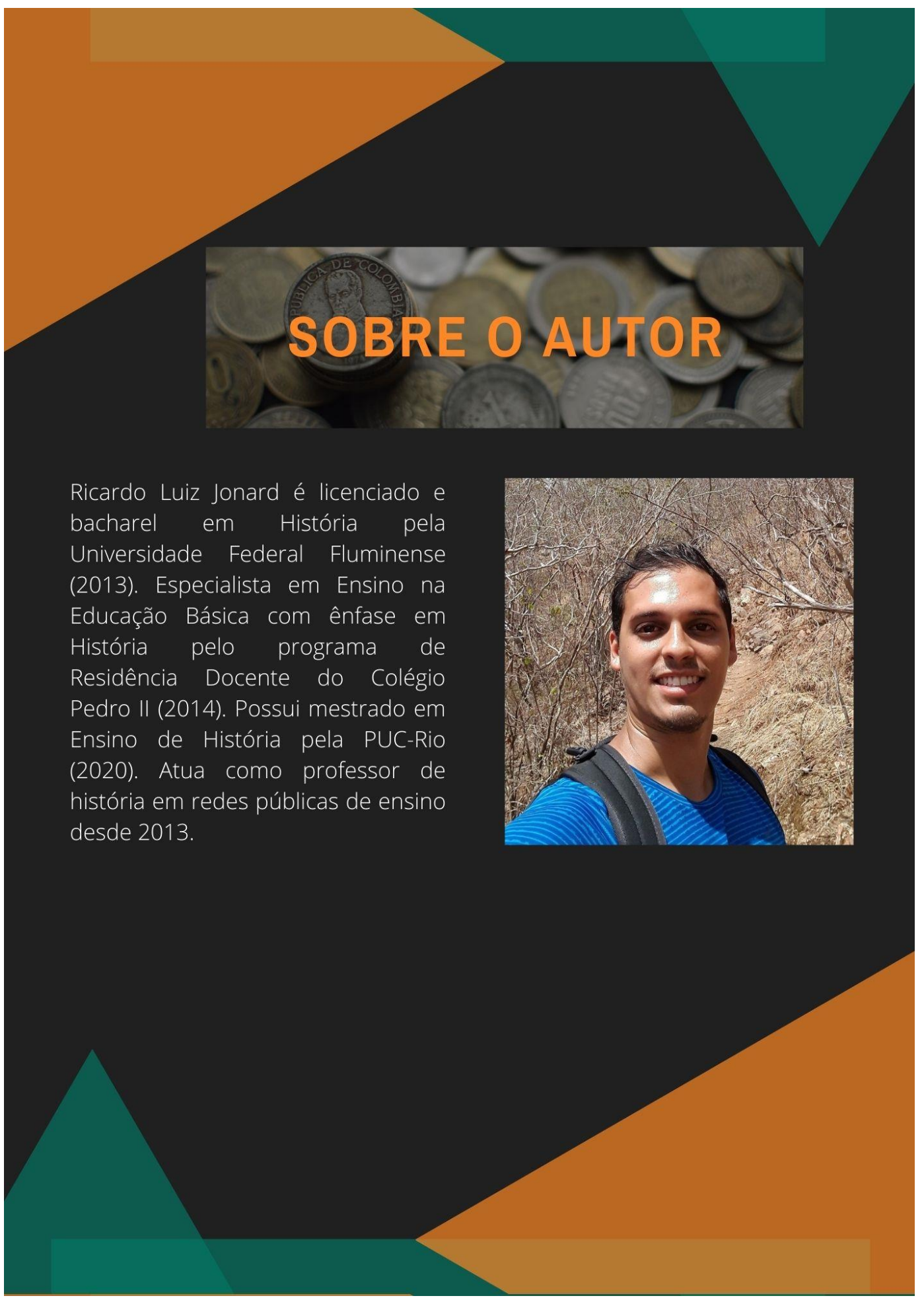




\section{APRESENTAÇÃO}

Caro professor, nas páginas a seguir você encontrará um guia para o uso das moedas nas suas aulas de história. Estamos sempre à procura de novas metodologias e reflexões através de publicações visando nosso aprimoramento, pensando sempre no melhor para os nossos alunos. Neste trabalho, a busca por boas práticas e inovação, que valorizam a sala de aula como universo de construção de conhecimento, promovendo a interação subjetiva dos alunos com o conhecimento pela sua vivência é o diferencial. Este manual é resultado da pesquisa de mestrado intitulada "A numismática na sala de aula: moedas que contam histórias" inserida no programa de Mestrado Profissional em Ensino de História (PROFHISTÓRIA). A partir de uma série de atividades focadas no manejo de moedas, a pesquisa centrou-se na apresentação de um estudo de temas canônicos do currículo escolar, circunscritos à História do Brasil Republicano. O objetivo principal consistiu em promover a construção do conhecimento histórico na educação básica, colocando o aluno como sujeito da produção de saberes e o professor como mediador deste processo. O guia apresenta um resumo objetivo de toda a pesquisa visando à aplicação da numismática durante as suas aulas. O texto do guia é apresentado em formato dirigido, assim como as atividades sugeridas. Em caso de dúvidas sobre os autores utilizados ou um interesse em aprofundar nos assuntos abordados, o texto da dissertação deve ser consultado.

Professor Ricardo Luiz Jonard 


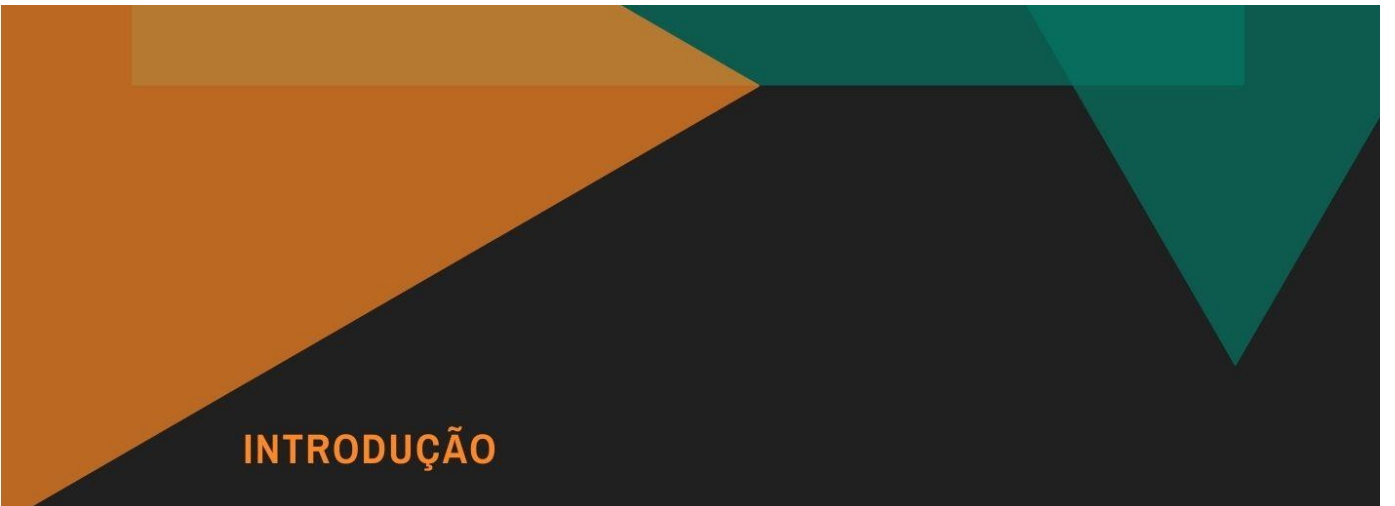

O que há de tão interessante em moedas antigas? Por que estes objetos despertam tanto o interesse de colecionadores? Você, professor, já experimentou utilizá-las em suas aulas de história? Imagine um aluno seu entrando em contato com uma fonte histórica tão genuína como uma moeda. Seguramente, será uma aula muito empolgante. Possibilitar o contato do educando com a numismática na sala de aula e promover a construção do conhecimento histórico é a nossa missão.

As moedas são testemunho de seu próprio tempo. Elas circularam pelas mãos das pessoas em todas as eras desde a antiguidade; após séculos de coadjuvantismo, ressurgiu com a revolução comercial da Europa medieval a partir do século Xl; exaltaram figuras de líderes como Júlio César, no denário Romano, e Getúlio Vargas, em seus réis e cruzeiros no Estado Novo; impulsionaram revoltas urbanas, dos vinténs aos vinte centavos; da prata de Potosí ao níquel Soviético, metais que deixaram registros materiais valiosíssimos por onde passaram; sua cunhagem é resultado da ação dos homens que ao intento de melhor regular a economia e as trocas comerciais deixaram como evidência não apenas aspectos econômicos das sociedades, como também políticos e socioculturais.

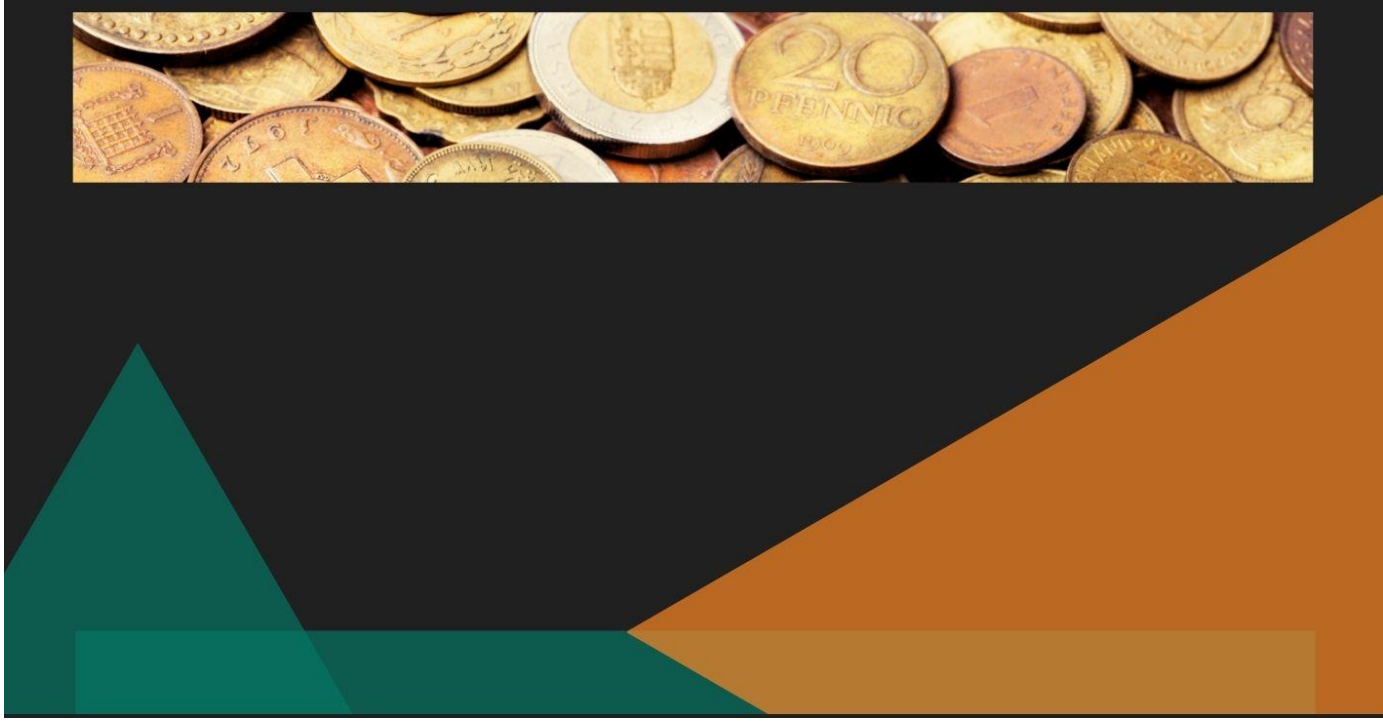




\section{Um pouco sobre a numismática}

A numismática é o estudo científico das moedas, cédulas e medalhas. A análise numismática pode oferecer ao historiador uma gama de informações através de uma apurada metodologia e de técnicas de pesquisa específicas. A origem do nome numismática vem do grego nomisma e do latim nummus, ambos os termos utilizados por estes povos para designar suas moedas. Já o termo moeda, por sua vez, origina-se em referência a deusa romana protetora do dinheiro, Juno Moneta, cujo templo na cidade de Roma cunhavam-se moedas. O nome Moneta é oriundo da palavra latina moneo que significaria "algo que nos lembre, que nos traz à memória", muito sugestivo sobre o mundo de possibilidades que a numismática pode proporcionar aos estudos históricos. Dentre as múltiplas possibilidades de informações que uma fonte desta importância pode oferecer destaca-se a economia, a cronologia, a metrologia, a epigrafia, a heráldica, a simbologia, a iconografia, a geografia, bem como a metalurgia. Todas estas possibilidades de análise estão atreladas a determinados processos históricos, fornecendo uma gama de possibilidades aos professores de história em suas aulas.

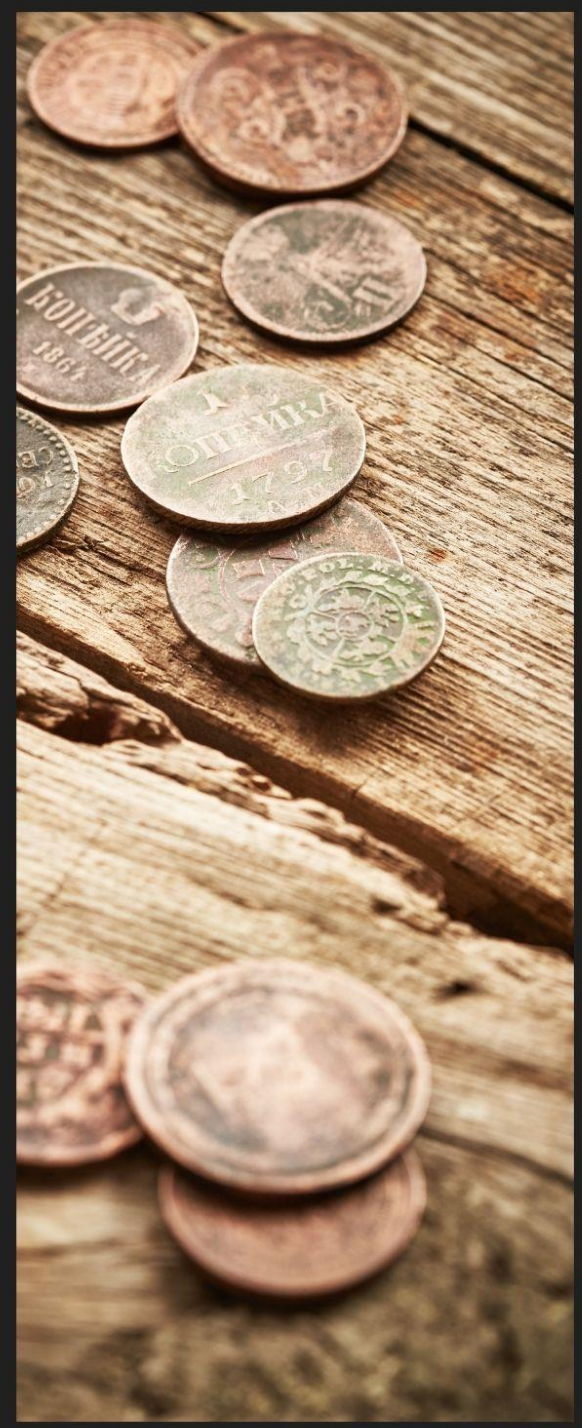




\section{Seleção de Fontes Numismáticas}

A seleção das moedas para o trabalho com a numismática em sala de aula pode se dar de duas formas. Inicialmente pode-se pedir aos alunos que levem suas próprias moedas para a escola. Isso é viável quando as fontes pedidas não forem de difícil acesso, como o caso da atual família do Real. Outra possibilidade é o professor levar as fontes para a análise. Se o docente não for colecionista e nem entusiasta da numismática ele pode montar seu pequeno acervo para o uso na escola.

Um bom lugar para ter um contato inicial com este material é o website Moedas do Brasil[1]. Neste sítio, pode-se buscar muita informação sobre a numismática brasileira e buscar através de um vasto catálogo as fontes necessárias para o desenvolvimento dos trabalhos. Para montar uma pequena coleção a sugestão é buscar através de antiquários, feiras de antiguidades, pela internet através do website Mercado Livre[2] ou em lojas especializadas em numismática. Na cidade do Rio de Janeiro, uma boa dica é garimpar na tradicional feira de antiguidades da Praça XV que ocorre aos sábados, ou recorrer as tradicionais casas de numismática no centro da cidade, como a Numismática Vieira[3] ou a DPL Numismática[4].

Moedas do período Republicano brasileiro (recorte temporal desta pesquisa) são mais fáceis de encontrar, pois foram cunhadas em maior quantidade, além de o material utilizado ser mais resistente. Essa maior quantidade disponível resulta, inclusive, no preço mais baixo de investimento na montagem de uma coleção. Quem não dispõe de tempo para a busca e nem dinheiro para isso, uma simples impressão colorida das moedas para se trabalhar na escola pode ser utilizada. Os modelos podem ser retirados no website do catálogo de moedas citado anteriormente. Embora surta efeitos pedagógicos importantes, é válido destacar que a utilização de impressões coloridas das moedas irá suprimir o encantamento oferecido aos alunos de poder aprender história manuseando fontes históricas peculiares e originais.

[1] http://www.moedasdobrasil.com.br/moedas [2] https://www.mercadolivre.com.br/ [3] Tradicional casa de numismática 


\section{Descrição da moeda}

Para analisar uma moeda é preciso estabelecer um preciso rigor técnico e metodológico sobre o material utilizado. Entender alguns termos e elementos da numária se faz necessário para que se possa "perguntar" ao documento o que o historiador busca compreender. Acredita-se que este conhecimento técnico pode ser ensinado ao aluno para que o mesmo possa fazer as reflexões que esta pesquisa propõe. Primeiro é preciso entender a morfologia de uma moeda. Ela é composta do bordo, orla, legenda, campo e exergo, como na imagem abaixo:

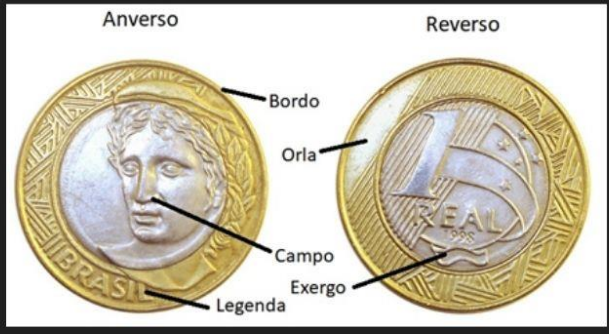

Sabe-se que toda moeda possui duas faces, as chamadas cara e coroa. Na numismática elas possuem um nome técnico. A face onde geralmente encontram-se as efigies (representação de um personagem) e brasões é chamada de anverso. Já a face onde se registra o seu valor é conhecido como reverso.

O bordo é a parte que delimita as duas faces da moeda, na espessura do disco, na qual é impressa a serrilha ou outro desenho. Para facilitar a compreensão dos alunos, pode-se utilizar outros termos ou maneiras para que compreendam termos tão técnicos, como o termo lateral, por exemplo.

Orla é a beira da face da moeda, em geral ligeiramente elevada, para proteger o desenho principal do desgaste, e que é frequentemente desenhada. O termo orla é de fácil assimilação pelos alunos, palavra muito associada à praia ou ao litoral, na geografia. Pode-se chamá-la de beira, no caso do trabalho com alunos mais novos.

A legenda é a inscrição com o nome do país, do soberano e seus títulos, ou da cidade, ou ainda frases. Talvez este seja o termo de mais fácil compreensão pelo educando. Legenda está nos filmes, nas fotos, nos documentos apresentados nos livros didáticos, ou seja, o aluno está mais habituado a entender este conceito e identificá-lo no material numismático não é tarefa difícil.

O campo é o espaço central da moeda, no qual aparece o motivo principal ou os símbolos escolhidos pela autoridade emissora. Por ser mais difícil assimilá-lo, pode-se usar o termo meio ou centro para que os alunos melhor entendam qual parte da moeda a analisar.

Já o exergo é a terminologia mais complicada, pois além do nome pouco conhecido ainda pode ser confundido com a legenda. Esta parte está situada entre o campo e a orla, na parte inferior. É onde se coloca a data da moeda. Para os estudantes, pode-se suprimir a utilização deste termo e apenas pedir a identificação da data de cunhagem. Vale ressaltar que o termo "cunhagem" é o mais adequado para designar a fabricação de objetos de metais, principalmente as moedas.

Estas são apenas sugestões de adaptações terminológicas, mas deve-se sempre incentivar o conhecimento de novas terminologias para que os alunos conheçam novas realidades e possibilidades.

Outras observações pertinentes sobre uma moeda que muito podem ajudar a compreendê-la são: o peso, a forma e a dimensão, o estado de conservação e o metal. Estes fatores podem ser de fácil compreensão pelos alunos, ou não, como no caso do metal utilizado na cunhagem do material, sendo o professor o responsável por orientá-los caso haja dúvidas. 


\section{Conservação, limpeza e acondicionamento das moedas}

O trabalho com a numismática em sala de aula pode ser uma oportunidade para fazer os alunos entenderem a importância do cuidado com o patrimônio cultural. Assim, pretende-se, através de atividades práticas, demonstrar a importância da conservação, da limpeza e do acondicionamento das moedas.

Incialmente, três dicas são fundamentais para a preservação destas fontes: primeiro, as moedas precisam ser limpas após o seu manuseio; segundo, jamais acondicionar conjuntamente moedas feitas a partir de metais diferentes; e por último, evitar que as moedas fiquem expostas por muito tempo ao ar e a umidade

E como armazená-las e limpá-las para evitar seus desgaste? Em relação ao armazenamento a primeira opção que surge, sendo também a mais econômica, são os envelopes de papel. Além de viável, no próprio envelope podem ser escritas as informações pertinentes à moeda. Porém o problema do papel é que com o tempo ele solta substâncias que podem prejudicar o estado de conservação das moedas. Sendo assim, ao optar pelo uso destes, eles precisam ser trocados constantemente.

Outra opção é o uso de álbum com folhas plásticas com divisórias para a guarda do material. Deve-se ter atenção a qualidade do material plástico, pois a baixa qualidade do plástico pode influenciar na conservação do metal-moeda. Recomenda-se optar por utilizar folhas de acetato, pois estas geralmente não apresentam deformidades com o tempo. Também existe uma embalagem muito comum chamada de holder (ou alvéolo) que são cartões rígidos e vazados protegidos em folhas de acetato. Estes itens podem ser encontrados em casas especializadas de numismática, sendo as folhas e os alvéolos vendidos de forma avulsa ou em conjunto com fichário em capa dura no caso das folhas plásticas.

Existem também possibilidades que vão depender de maiores investimentos. Uma embalagem muito utilizada, principalmente para 0 transporte das moedas, são embalagens feitas em acrílico transparente. Mais custosos são os chamados medalheiros ingleses, que possuem uma estrutura com diversas gavetas separadas para guardar a moeda isoladamente. Apesar do alto custo, o medalheiro inglês apresenta uma excelente opção para manter a moeda em boas condições para a sua preservação. Já em relação à limpeza existem visões contraditórias entre limpar ou não a moeda. Muitos numismatas defendem e preferem não limpá-la optando em mantêla em seu estado natural. Existe um indicador de sua preservação que é a pátina, composto químico que se forma na superfície da peça causado pela exposição a elementos e ao clima ou seja, é resultado da ação do tempo no metal. Para os dedicados ao estudo da moeda, a pátina pode ser um indicativo da sua autenticidade, bem como pode oferecer informações relevantes quanto a sua datação e origem. A limpeza mal feita, neste caso, pode retirar a pátina da peça mudando suas características naturais.

A opção pela limpeza da moeda deve seguir um rigo técnico com bastante cuidado para evitar danos às peças. Existem também divergências entre especialistas quanto aos procedimentos mais adequados. Aqui, optou-se por descrever a forma mais simples $e$ acessivel, sem o uso de produtos químicos e com procedimentos pouco invasivos.

De inicio é preciso ter alguns materiais como: sabão neutro; flanela; papel absorvente; escova de dente escova de latão; palitos de dente; luvas; e um secador de cabelo. Assim seguem os procedimentos destacadospelo guia:

$1^{\circ}$ passo: Deixar a moeda em água morna. Isso fará com que o excesso de sujeira fique mais macio, facilitando processo de limpeza.

$2^{\circ}$ passo: Manusear as moedas com cuidado para não danificá-las e segurar apenas pela borda. Fazer a limpeza de forma suave, utilizando a flanela, a escova de dente e de latão e os palitos. Não é necessário aplicar força para limpar sua peça. Utilizar sabão neutro, pois é um produto que não agride sua peça. Outros produtos possuem componentes que não são indicados para moedas.

$3^{\circ}$ passo: Após concluir a limpeza da peça, lavá-la com bastante água corrente. Não pode haver vestígios de sabão.

$4^{\circ}$ passo: Pode-se usar o secador de cabelo em temperatura morna, se precisar, para acelerar o processo de secagem. Fazer uso de papel com alta absorção para secar suas moedas completamente. Guardá-la com qualquer vestígio de umidade resultará em oxidação. Deixa a moeda secando por um ou dois dias ao ar livre para secagem total da peça.

$5^{\circ}$ passo: Após a limpeza e a secagem é o momento de guardá-la, utilizando os ensinamentos descritos sobre o acondicionamento de moedas.

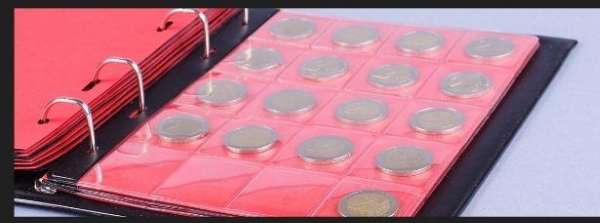




\section{- uso da tecnologia dos Smart Phones para a identificação de moedas}

Fazer o uso de novas tecnologias tão presentes na realidade dos alunos é uma forma de transformar o ensino tornando a escola um ambiente mais atrativo. Neste guia foram selecionados dois aplicativos de celular que podem auxiliar o aluno no processo de identificação das moedas bem como ajudar na organização e gestão do acervo numismático: o Coinoscope e o Collectgram, ambos disponíveis nos sistemas operacionais Android e IOS. O primeiro é capaz de identificar as moedas do usuário a partir do uso da câmera do celular. O aplicativo faz um escâner da peça identificando-a na sua base dados e fornece diversas informações sobre o item. Já o Collectgram permite consultar informações sobre moedas a partir de um catálogo com mais de 100 mil peças cadastradas. 0 diferencial deste app é que nele é possível criar e organizar o acervo do colecionador, facilitando a sua gestão. 


\section{Atividades}

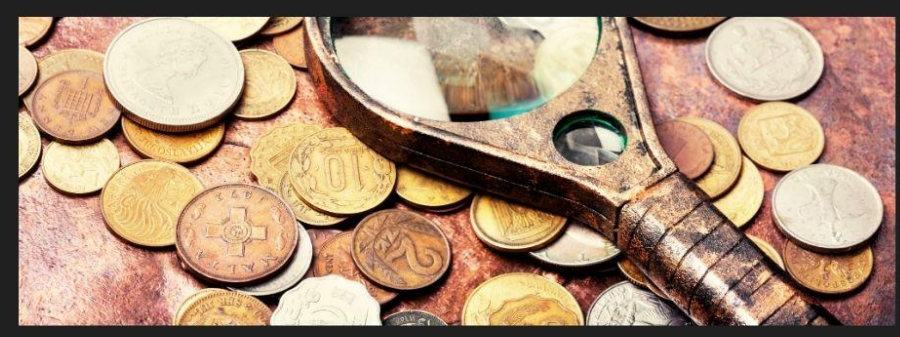

Nas páginas abaixo seguem as atividades trabalhadas durante a pesquisa como sugestão ao professor que desejar utilizar a numismática como ferramenta de construção do conhecimento histórico em suas aulas. 


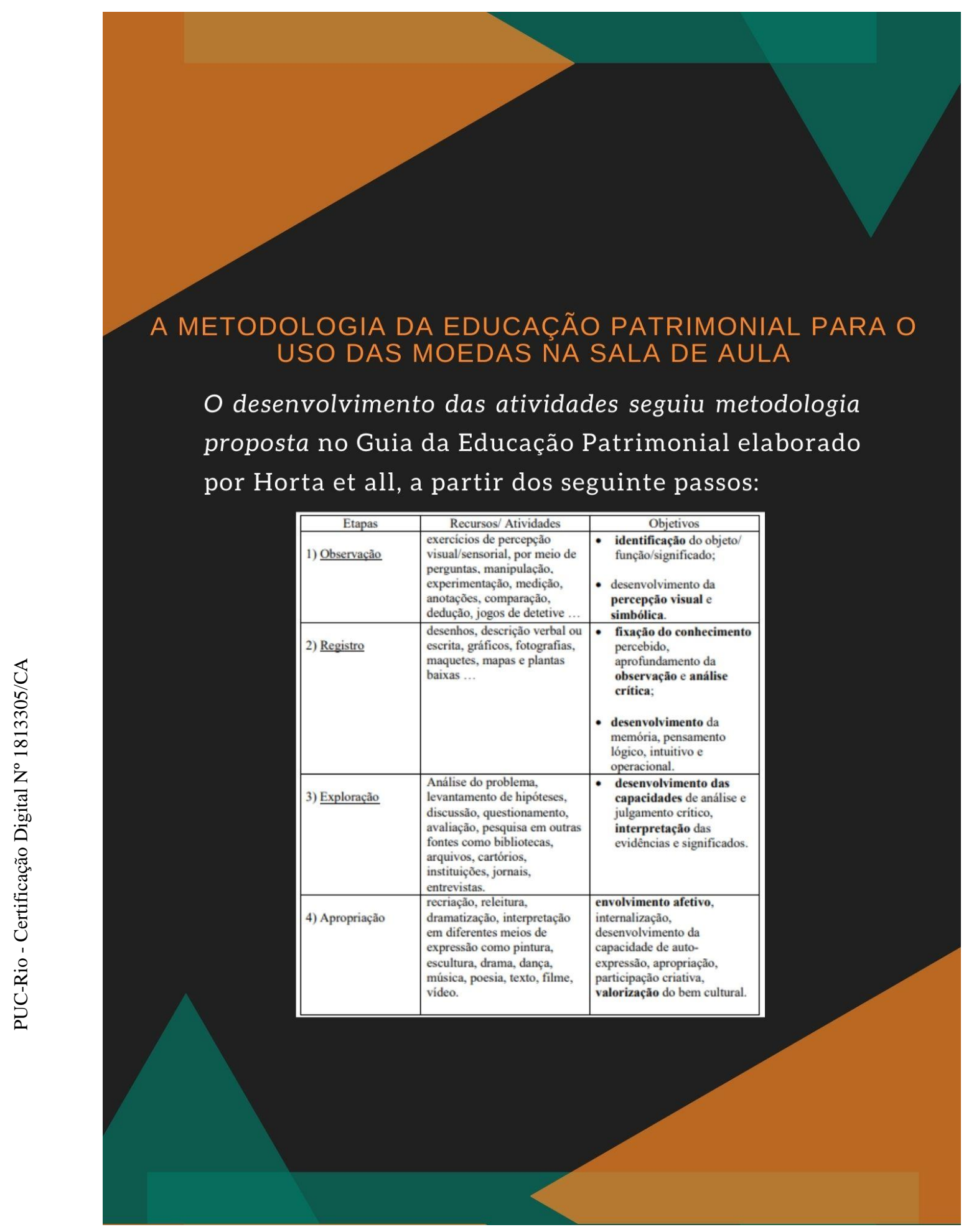




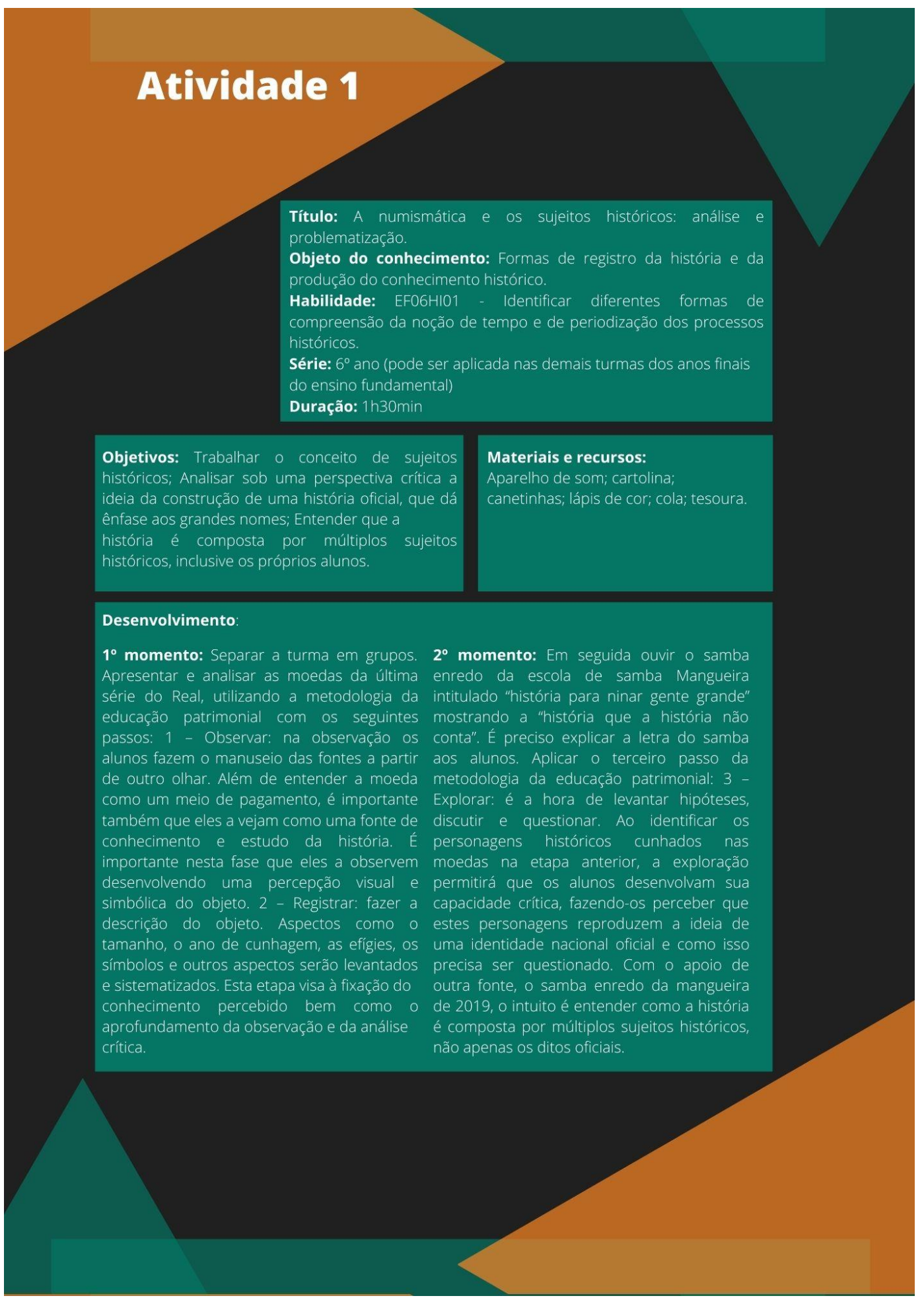


Produção de saberes/Avaliação: Como atividade final utilizar o quarto passo da metodologia da educação patrimonial: 4 -Apropriar: a apropriação permite que eles façam recriações e releituras. Sendo assim, foi proposto que eles recriassem novas moedas para o Brasil, só que desta vez contemplando efígies de sujeitos historicamente negligenciados pelos estudos históricos ou até mesmo retratando a si mesmos, amigos, ou familiares permitindo que eles se vejam como sujeitos que compõem a história. Pretende-se com isso desenvolver a capacidade

de auto expressão, apropriação, participação criativa e valorização do bem cultural.

\section{Fontes históricas utilizadas:}

Letra do Samba enrendo do G.R.E.S. Estação Primeira de Mangueira (2019) https://www.letras.mus.br/sambas/mangueira-2019/ Acesso em: 03 de ago. de 2020.

Moedas da $2^{a}$ família do Real - http://www.moedasdobrasil.com.br/moedas/catalogo.asp?s=1 Acesso em 03 de ago. de 2020 


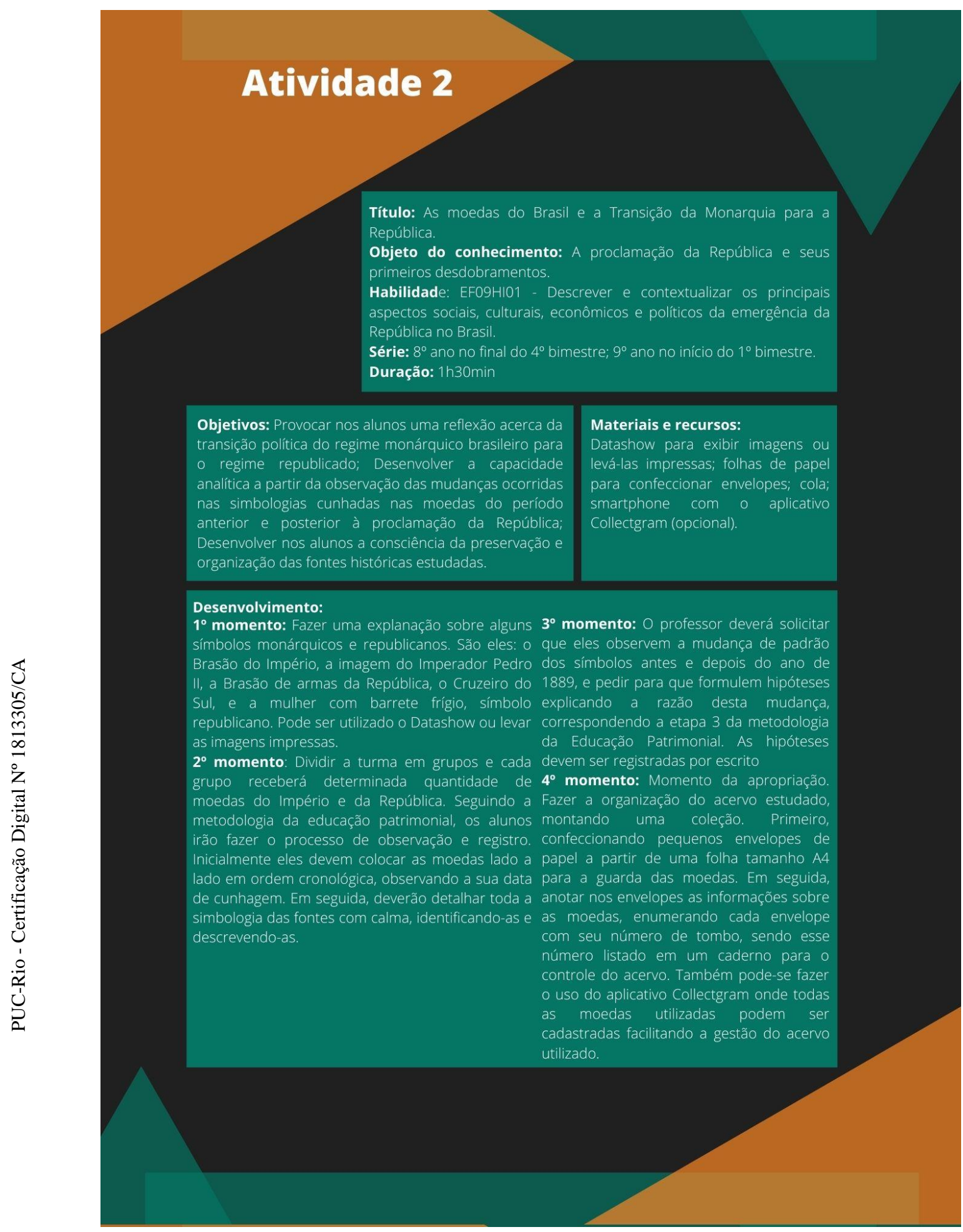




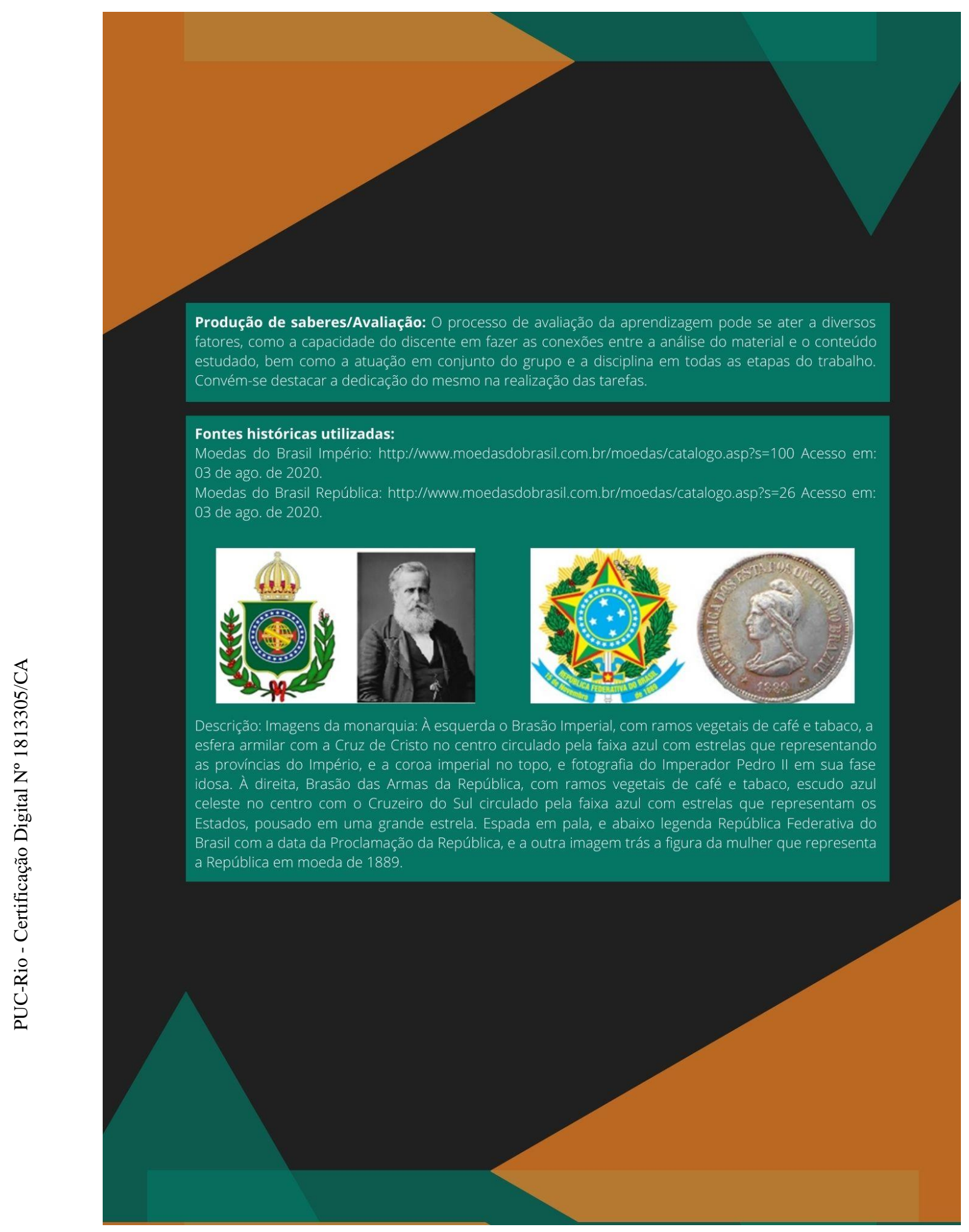




\section{Atividade 3}

Título: Estado Novo: a numismática e o culto a imagem do presidente

\section{Vargas}

Objeto do conhecimento: O periodo Varguista e suas contradiç̃es.

Habilidade: EFO9HIO6 - Identificar e discutir o papel do trabalhismo como força política, social e cultural no Brasil, em diferentes escalas (nacional, regional, cidade, comunidade).

Série: $9^{\circ}$ ano.

Duração: 20 minutos (início da aula, introduzindo a Era Vargas).

Objetivos:

Compreender a estratégia varguista no culto a

imagem do presidente durante o Estado Novo

através das moedas da época.

\section{Materiais e recursos:}

Listagem de todos os presidentes da

República do Brasil com o ano do

mandato.

\section{Desenvolvimento:}

$1^{\circ}$ momento: Separar a turma em duplas. e efígies gravados nos anversos de cada moeda Entregar aos alunos moedas do período recebida, os alunos deverão identificar o único republicano e uma lista constando todos os presidente da República que durante seu presidentes da época. Sugere-se que cada governo emitiu moedas com a sua própria dupla receba em torno de oito moedas para a efígie.

análise, sendo uma obrigatoriamente cunhada $3^{\circ}$ momento: Etapa 3 da Educação entre os anos de 1938 e 1945, onde figura a Patrimonial: Exploração. O professor irá propor efígie do presidente Getúlio Vargas. As outras aos alunos que formulem hipóteses para a moedas devem conter efígies de outros ocorrência de moedas com a efígie do personagens para tornar a analise mais presidente Vargas durante seu próprio governo desafiadora. $\quad$ podendo ser feita de forma oral estimulando a $2^{\circ}$ momento: Etapa da observação e registro. participação de todos, ou escrito no caderno Como apoio da lista com os nomes de todo os Após esta análise documental e presidentes da república e observando problematização, dar-se-á inicio a aula atentamente as datas de cunhagem das expositiva sobre a Era Vargas.

moedas bem como os símbolos

Produção de saberes/Avaliação: Como é uma atividade rápida, a avaliação da aprendizagem desta proposta pode se dar a partir do comprometimento do aluno e das hipóteses formuladas por eles.

\section{Fontes históricas utilizadas:}

Moedas do Estado Novo - http://www.moedasdobrasil.com.br/moedas/catalogo.asp?s=16 Acesso em 04 de ago. de 2020.

Moedas período Republicano: htto://www.moedasdobrasil.com.br/moedas/catalogo.asp? $s=202 \& x m=1353$ Acesso em 04 de ago. de 2020 


\section{Atividade 4}

Objeto do conhecimento: A ditadura civil-militar e os procesos de resistência.

Habilidade: EF09HI20 - Discutir os processos de resistência e as propostas de reorganização da sociedade brasileira durante a ditadura civil-militar.

Série: $3^{\circ}$ ano do ensino médio. Pode ser aplicada no $9^{\circ}$ ano com maior auxílio do professor.

Duração: 1 h30min

Objetivos: Perceber as mudanças econômicas do período através de algo muito presente no cotidiano das pessoas: o dinheiro; Estimular a elaboração e resolução de problemas que envolvam porcentagens.

\section{Materiais e recursos:}

Tabela entregue aos alunos (anexada na página abaixo)

\section{Desenvolvimento:}

$1^{\circ}$ momento: A turma deverá separar-se em equipes, e a eles serão apresentadas as fontes numismáticas, constando moedas de Cruzeiro dos anos de 1964 até 1985. Os grupos vão receber as moedas e observá-las.

$\mathbf{2}^{\circ}$ momento: Etapa do registro. Eles devem ordenar as moedas em segmentos respeitando uma sequência cronológica da época, conforme tabela e instruções que será entregue. A tabela deverá ser preenchida com as informações pedidas. Os contextos econômicos da ditadura devem ser previamente explicados, são eles 1964 - 1967 (PAEG); 1968 -1973 (milagre econômico); 1974 - 1979 (marcha forçada)
1980 - 1983 (crise da dívida) e 1984 - 1985 (crise da dívida). Obs: Os valores referentes ao ano de 1964 a 1967 deverão ser divididos por 1000 para equiparar-se aos demais períodos, em função do decreto do Cruzeiro Novo instituído a partir de 1967

$3^{\circ}$ momento: Momento da exploração. 0 professor deverá estimular a reflexão da turma com o intuito de fazer conexões entre o conteúdo e fontes previamente estudadas sobre as questões econômicas do período militar. Espera-se que os alunos associem as constantes alterações nos valores das moedas com a inflação, relacionada ao contexto de crise da economia.

\section{Produção de saberes/Avaliação:}

O processo de avaliação da aprendizagem pode considerar elementos como a atuação do educando no trabalho em grupo, o comprometimento e a sua disciplina. O principal aspecto a ser avaliado é o preenchimento da tabela a partir da análise das fontes. 


$$
\theta
$$




\section{Bibliografia:}

CARLAN . C. U.; FUNARI, P. P. As Moedas, a Numismática e o estudo da História São Paulo: Annablume/Fapemig/Unifal/Unicamp, 2012.

COSTILHES, Alain Jean. o que é numismática. Editora brasiliense. São Paulo, 1985.

GALLAS, Alfredo; GALLAS Fernanda Disperati. As moedas contam a história do Brasil. São Paulo. Magma Editora Cultural, 2007.

HORTA, Maria de Lourdes Pereira. GRUNBERG, Evelina. MONTEIRO, Adriane Queiroz. Guia Básico de Educação Patrimonial. Instituto do Patrimônio Histórico e Artístico Nacional, museu Imperial, 1999

PEREIRA, N. M. e SEFFNER, F. O que pode o ensino de história? Sobre o uso de fontes na sala de aula. Anos 90, Porto Alegre, v. 15, n. 28, p.113128, dez. 2008.

VIEIRA R. M. L. Alguns princípios gerais de conservação de moedas e o processo de limpeza mecânica adotado no Museu Histórico Nacional. Rev. do Museu de Arqueologia e Etnologia, São Paulo, 2:133-136, 1992.

\section{Sites Web:}

CARAVELAS COLEÇÕES. <https://www.caravelascolecoes.com.br/>

MOEDAS DO BRASIL <http://www.moedasdobrasil.com.br/moedas/> 


\section{ANEXO 2}

Respostas da turma 801 (2019):

\section{Prefeitura Municipal ke Quatis}

Ciep492 Municipalizado Macaino Machad. D'Elas

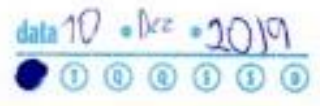

Quatis 10 de dezembro te 2019.

Ohino

Ped: Ricardo

turima: 801

- Apartir dos unoedas analizadas, formule uma hipótex sobar o que acontecen us govermo do Bragil na pasrigen

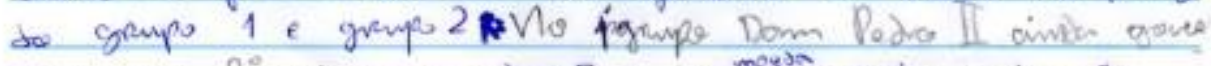

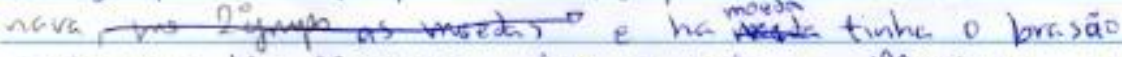
do imperio. No 20 gappo, tem a conto da Merciane ea sombolo re Republica.

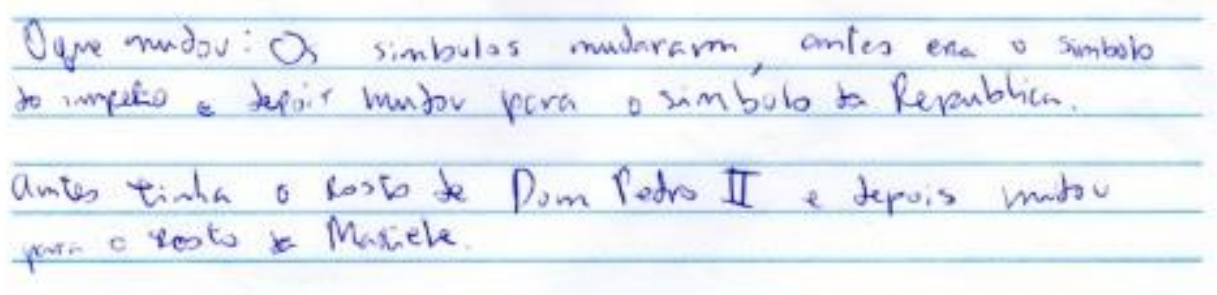


Psefuituxa Thunicipal de Tuatis.

dith (1) (1) (1) (1) (1) (1)

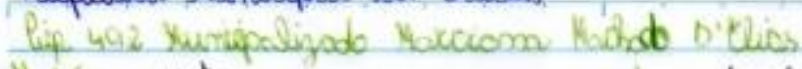

Matínic Hétria

bot: $b / s_{2}$ isa

Nome

tewima: sos

Prquiver: Ricosdo

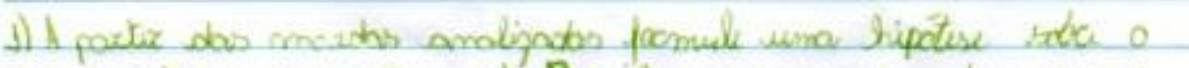

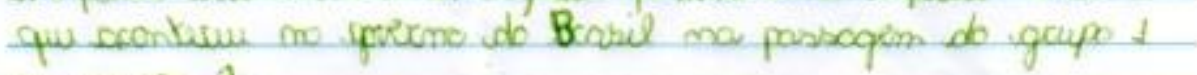
ac eque 2

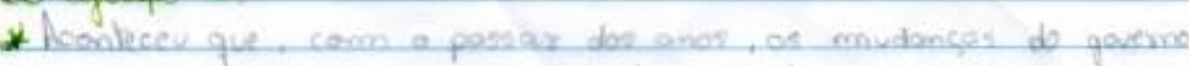

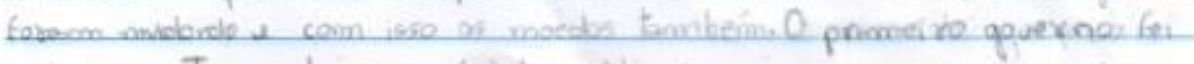

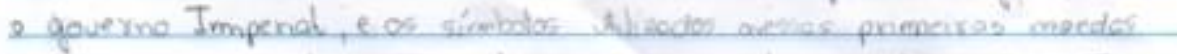

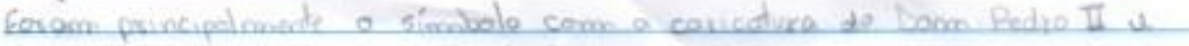

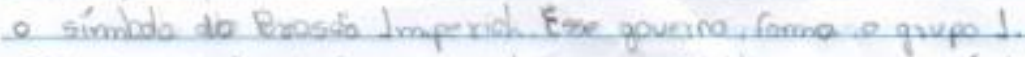

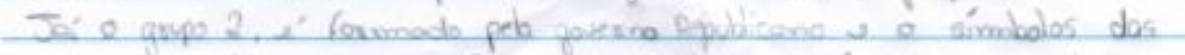

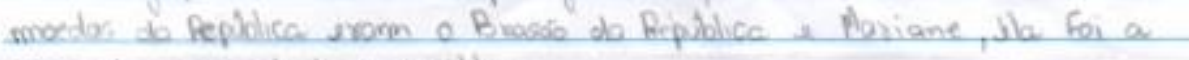
principol repieseribate de Repulice.

cep 492 M MM DEllias

Nome

pidessorifa) Risandaso
Pereature municipal de quets Dala- 1011212019 Moterio = Historice. torme. 80

* a pattir das arrolisados, formulas uma hiptse sabe aque crontecele vo gerverno do Brasi va passagem do grupe 1 ao grupo 2 wo gupo \& Jem Brasaro do imperio Dom pedro II has moedas 2 tem Brasão da rediblica no grupo e mariane remprensertou o simbolo da Repoblice 
DSTIOASIS

Escale: Cisp 492

\section{政}

Noms:

Dita: 101212018

Summa: in

1) A padir das madas analisadas, foumule uma hipitese

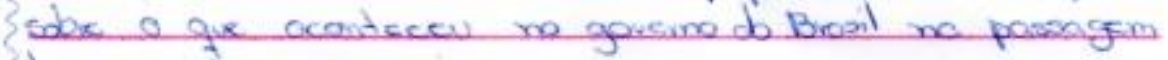
do appe 1 pan a gripe 2.

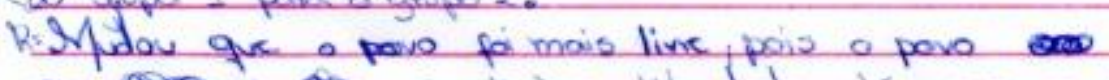

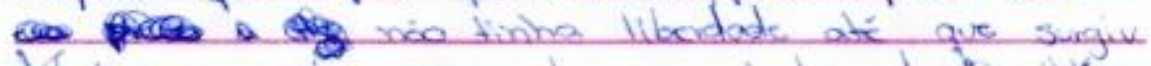

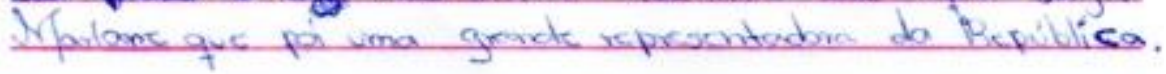

*2019" Prefature Huncpd de Mots -

\section{(6) (1) (10) (10) (1) (1) (1)} Cop 492 M. M N D. Ellas

marésia: Hiètário

Norre rorme Data: $30 / 52 / 2029$

Profesoser: Ricardo

Turmo: 80s

* Aportir dos moedos andisadas, formule umo hipótese sobre o que cocontereu no Governo do Brosil na possogarn do Gupol pora o 2.

Guppl: Moedo com imogem de Dom RechoII, av seje com a pacall ade. jovion bi bldment mudody, alles hovis reinde pra

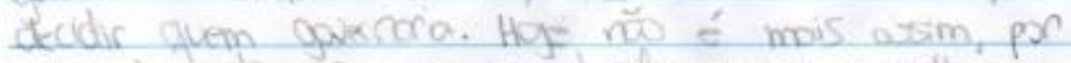
neb do vilo of pessos deccan quem, oscdier bera ses i (preschecte, uceostos, prekito...).

Grupl: Modto can thogern ok Morlate, Que Reportiou a Repíblica e que tombém Per poícté do- desendvinento do governo e tantém " aos maedos. 
Respostas da turma 901 e 902 (2020):

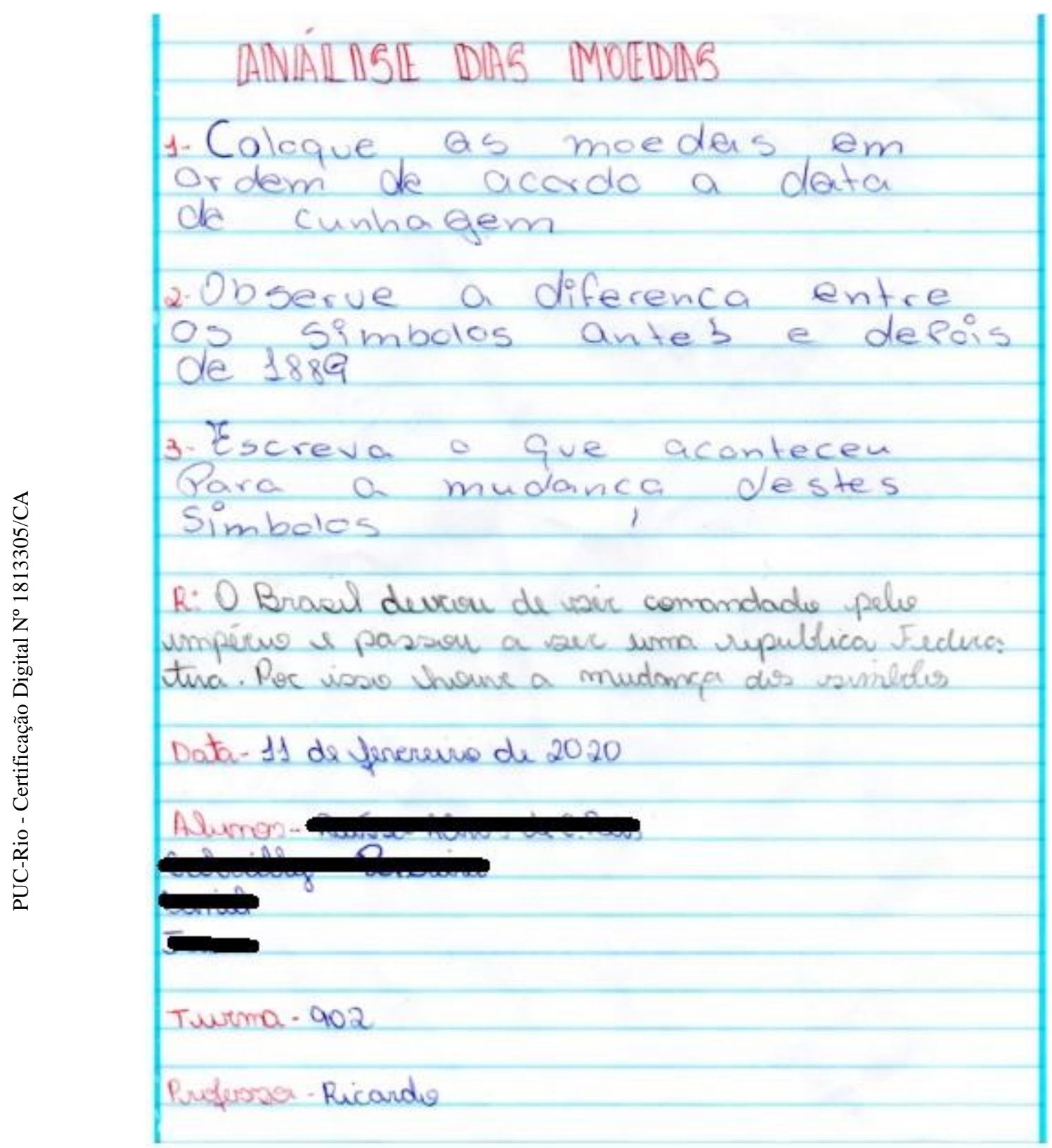


136

analize de moedas 4 \&

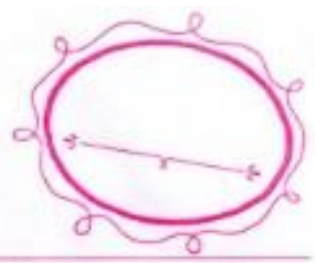

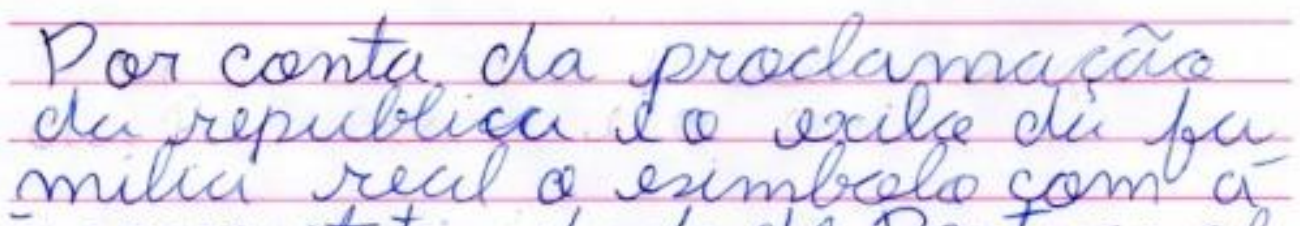
repreretestirendude de Portugual comecour a eser ce ourgeirce

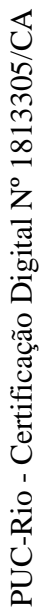

1- Segare as unasdar sm ardem de cacordo com a data de cunnagam

a) 3870

b) 0925

2. Desersere a diferemca entre as simbelas entu antes a depas Rilidifuença i que a moida de S8to la é da sepulbleca e do cono 1928 é censtrueda no terpo do simbalo xepulticano.

3. A partuc desta obsuragä, escrera a que acentecue no Brasil para a mudanga derte sumbalos.

$R=$ Aconteu grainde diferanga das mocdas entre o pe. riodo monár quice

Nome:

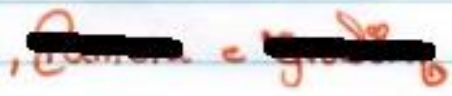




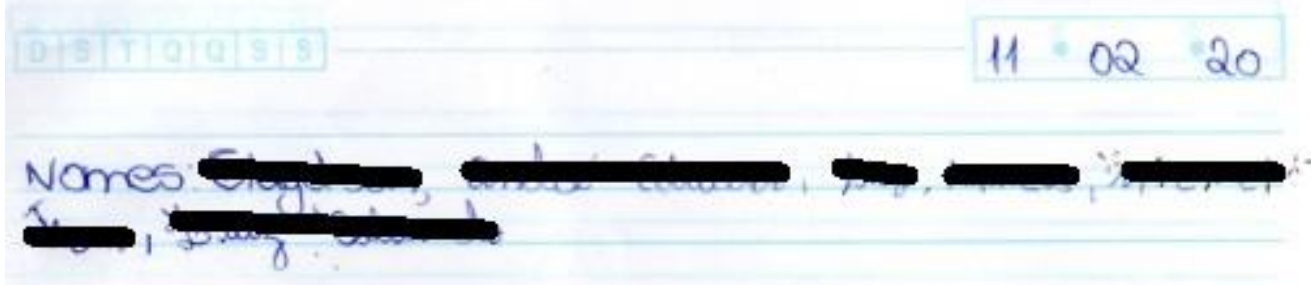

sata das moedas: 1870,1889 e 1922

Diserenca do simbolos: 1870-Brazáo, 1889-D. Pedvo If, 1922 -Mariana

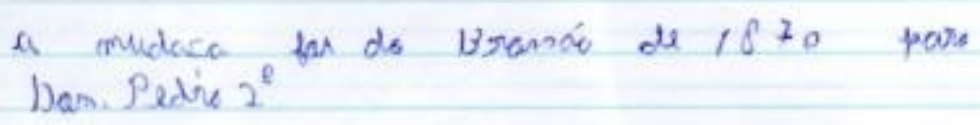

\section{História}

Alunos: Pawã Felipe, lechov, Wesley, Luiz Gustavo, Vinicius

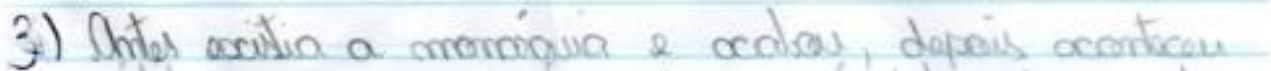

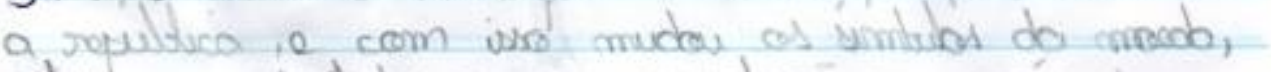

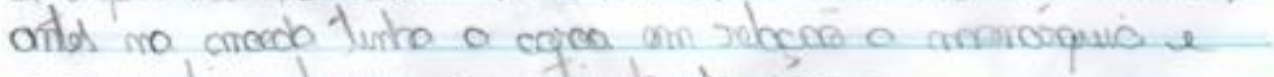
com a firm hauk a setirado da corac. 


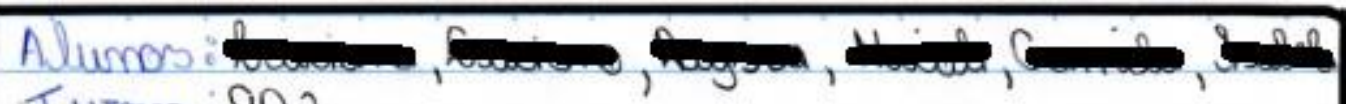
Tumma: 902

\section{Amalise dos Mosdos}

1- Croloque vars masdors em vordarn de ocordo. Audata de curtogem

2 - Obrserce la defíanca entur os sumbolos anters a depais le 1889.

3- Erscerra lo que vacontreele para a mudoncars derstas simblelos.

Com va mudanca do Govouno ora ramplotos dase mocidars fovarn mudande, Polque o ree from perderdo pedor de gerurar, Pors os me -

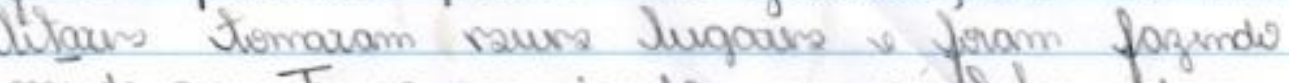

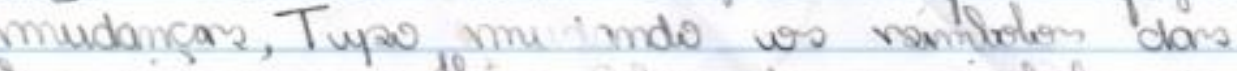

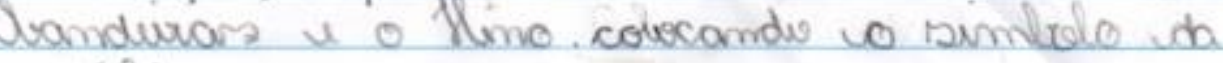
república.

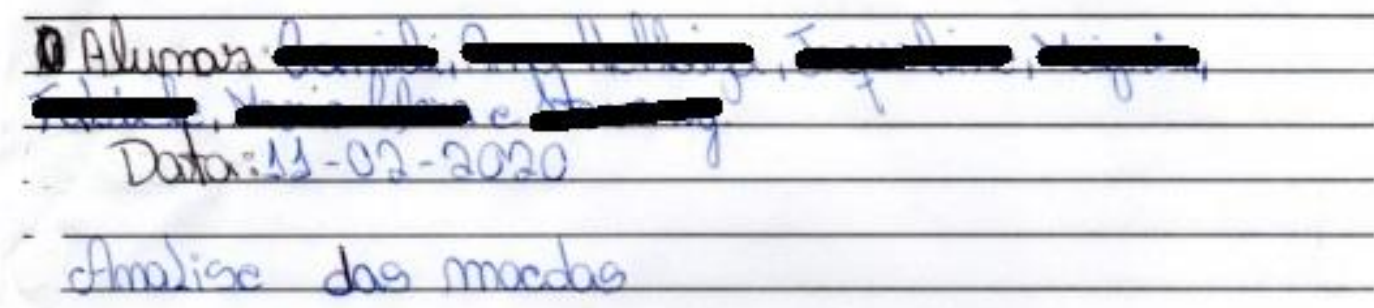

(1) Coloque as moedas em erdem de acords a dato de cumbagem. 1889, $1900,1928,1928$.

(2) (U) beerve a Difereme entre as simbolos antes

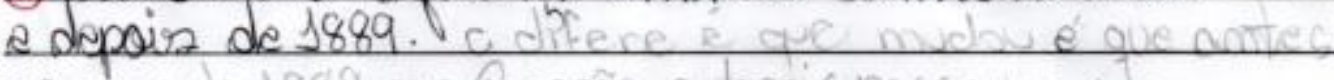

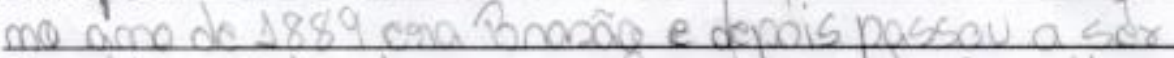

3) Eocorora o que aconteoces pana a mudamen Dentes símbolos. 


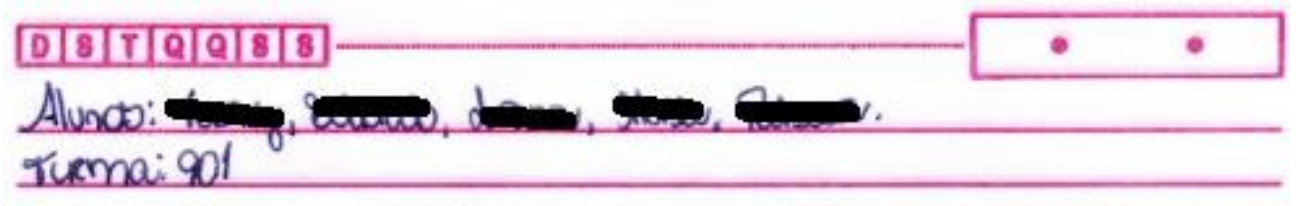

$1 \cdot 1870-1889 \cdot 1928$

2. Antes de 1889 de vepasurtava o Bravas smperial Ne dro de 1889 repeentios D. Pedeo in, em 1928

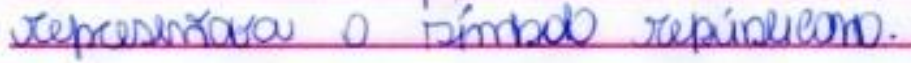

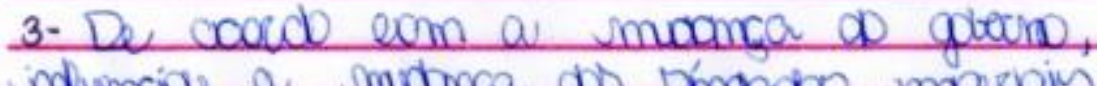

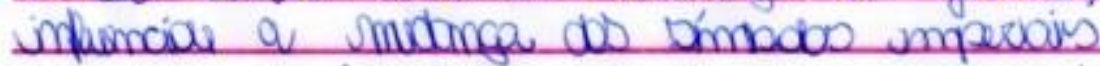
upaca us sombalds repubriearos el twa fecma de gotornaca. 


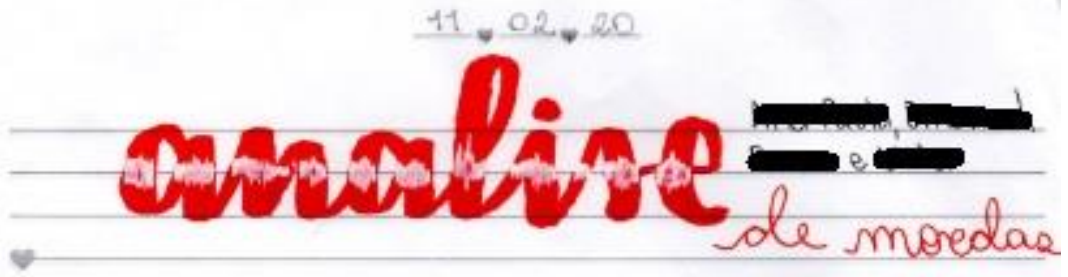

(1) Syare as madas em ondem de acondo com a data de cumhagem

(2) abserrs a diferença entre os simbidas grarados antes e depas da vano de 1889.

(3) A partir desta desurvaçäa, encurva o que mudou (acontencul) no Braril para a smudariça de rimbolos

- medar de 200 réus

ane 1874

nimbolo brasão dos armas da umpécus do Brasil

- morda 20 rus

ano. 4906 do Brmbile. brasar do supuiblico fedartiva

* As simbolus mudaram pela pata do mudamse da monárque pana va rupublica entäo is goreino ques mudance em tudo aquilo que se sejeria cue passodo 
Andise de macasos 11/0212020

(1). Separe as maedos em ardem de acardo cama dalla de launhogum 0 order conhagen de $1873 \mathrm{e}$

1927

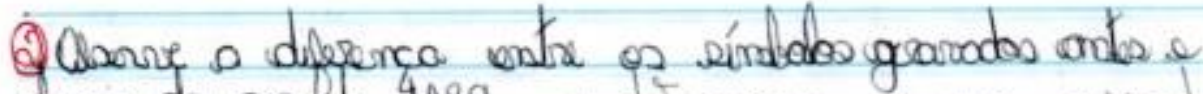
depoir do ano de Is89 a díterenca e que a roed de 1875 teridono encosio das arras do impeno do Brasile

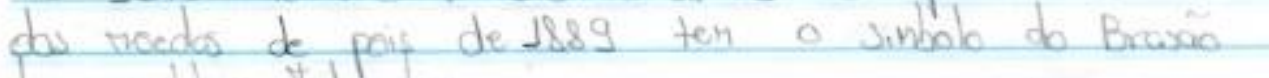

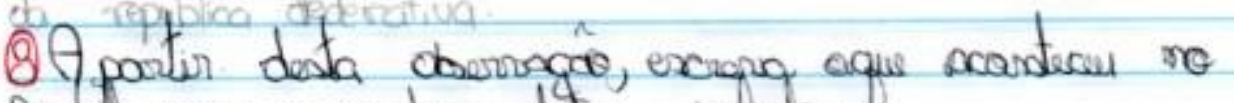
Brosil para a madomes distos simpalos.

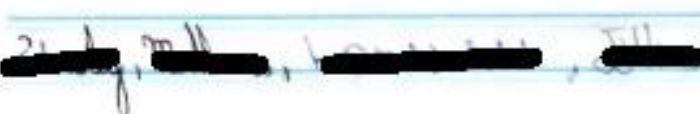


ANEXO 3

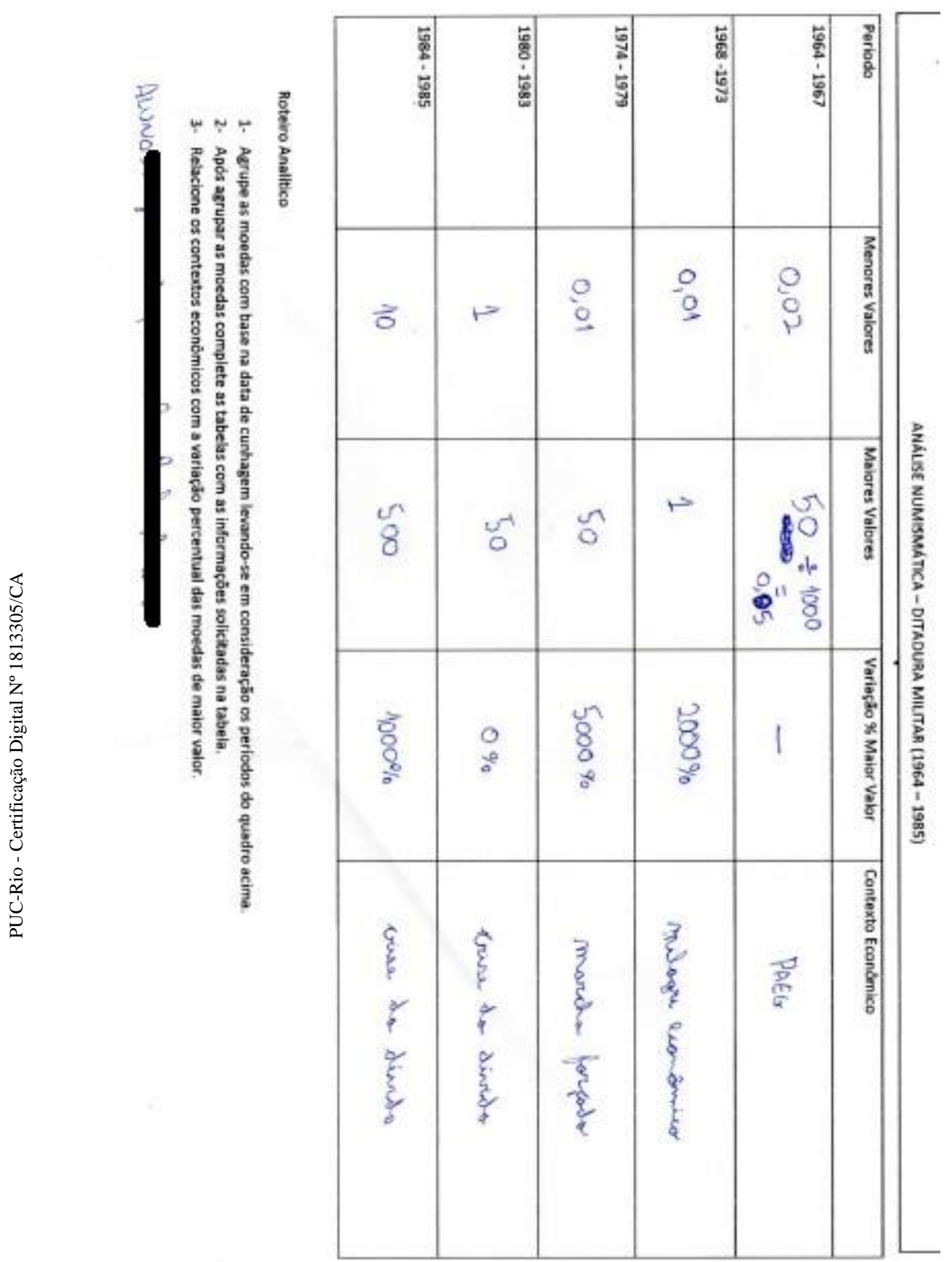

